\title{
EFEITO DE EXTRATOS AQUOSOS DO BASIDIOCARPO E MICÉLIO DE Lentinula edodes (SHIITAKE) SOBRE Colletotrichum sublineolum, Alternaria solani, Xanthomonas axonopodis pv. passiflorae e Tobacco mosaic virus (TMV)
}

\section{NIVEA MARIA TONUCCI}

Dissertação apresentada à Escola Superior de Agricultura "Luiz de Queiroz", Universidade de São Paulo, para obtenção do título de Mestre em Agronomia, Área de Concentração: Microbiologia Agrícola.

P I R A C I C A B A

Estado de São Paulo - Brasil

Agosto - 2004 


\section{EFEITO DE EXTRATOS AQUOSOS DO BASIDIOCARPO E MICÉLIO DE Lentinula edodes (SHIITAKE) SOBRE Colletotrichum sublineolum, Alternaria solani, Xanthomonas axonopodis pv. passiflorae e Tobacco mosaic virus (TMV)}

NIVEA MARIA TONUCCI

Bióloga

Orientador: Prof. Dr. SÉRGIO FLORENTINO PASCHOLATI

Dissertação apresentada à Escola Superior de Agricultura "Luiz de Queiroz", Universidade de São Paulo, para obtenção do título de Mestre em Agronomia, Área de Concentração: Microbiologia Agrícola.

P I R A C I C A B A

Estado de São Paulo - Brasil

Agosto - 2004 


\section{Dados Internacionais de Catalogação na Publicação (CIP) DIVISÃO DE BIBLIOTECA E DOCUMENTAÇÃO - ESALQ/USP}

\section{Tonucci, Nivea Maria}

Efeito de extratos aquosos do basidiocarpo e micélio de Lentinula edodes (Shiitake) sobre Colletrotrichum sublineolum, Alternaria solani, Xanthomonas axonopodis pv. passiflorae e Tobacco mosaic virus (TMV) / Nivea Maria Tonucci. - - Piracicaba, 2004.

$$
87 \text { p. : il. }
$$

Dissertação (mestrado) - - Escola Superior de Agricultura Luiz de Queiroz, 2004. Bibliografia.

1. Agentes antimicrobianos 2. Cogumelos comestíveis 3. Microrganismos I. Título

CDD 635.8 
“Senhor, que és o céu e a terra, que és a vida e a morte! O sol és tu e a lua és tu e o vento és tu! Tu és os nossos corpos e as nossas almas e o nosso amor és tu também. Onde nada está, tu habitas e onde tudo está-(o teu templo)-eis o teu corpo”.

Fernando Pessoa 


\section{DEDICO}

Aos meus pais, Alcides e Cecília, pelo amor incondicional.

À minha irmã Giane, pelo apoio e incentivo.

Ao Márcio, pelo apoio, convívio e carinho.

Às minhas avós Norma (in memorian) e Constança, exemplos de dedicação, simplicidade e dignidade... 


\section{AGRADECIMENTOS}

Agradeço ao Prof. Dr. Sérgio F. Pascholati pela orientação e ensinamentos, pelo incentivo e pela confiaça depositada em mim para a execução deste trabalho.

Ao amigo Dr. Robson M. Di Piero pelo muito de sua colaboração, amizade e apoio, sendo que jamais mediu tempo ou esforço para me auxiliar no desenvolvimento deste trabalho.

Ao amigo Maurício pelas sugestões, incentivo, ensinamentos e principalmente pela presença amiga e descontraída de sempre.

Agradecimentos especiais aos amigos André, Cris, Daniele, Elaine, Leonardo Cavalcante, Leonardo Toffano, Marizete, Nelson, Odair, Patrícia e Solange que de alguma forma contribuíram para a realização deste trabalho.

Ao Prof. Dr. Augusto Ferreira da Eira, pelo fornecimento dos cogumelos utilizados nos experimentos e pela atenção dispensada.

Aos funcionários Sílvia, Fernanda e Rodolfo, Heloísa, Pedro Arthuso, Marina, Jéferson, Edivaldo, Giovana, Sara, Carmen e Sandra pela atenção, boa vontade e amizade.

À Fundação de Amparo à Pesquisa do Estado de São Paulo (FAPESP) pelo apoio financeiro. 


\section{SUMÁRIO}

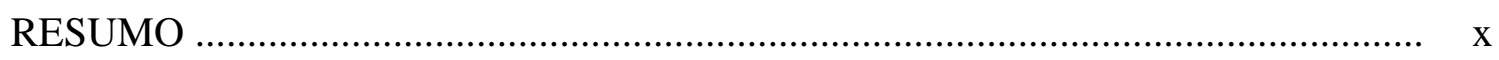

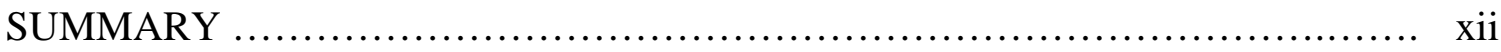

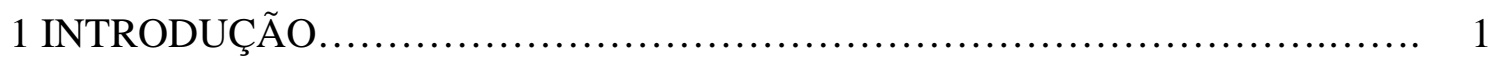

2 REVISÃO DE LITERATURA …………………………...............................

$2.1 \mathrm{O}$ cogumelo shiitake (Lentinula edodes) ............................................................... 3

2.2 Valor terapêutico e medicinal de L. edodes ............................................................. 4

2.3 Atividade antimicrobiana de L. edodes .................................................................. 6

2.4 Fitopatógenos utilizados no estudo ………………….......................................... 8

2.4.1 Colletotrichum sublineolum ..................................................................... 8

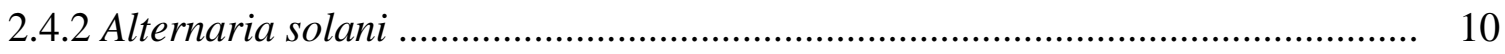

2.4.3 Xanthomonas axonopodis pv. passiflorae …….................................................. 11

2.4.4 Tobacco mosaic virus (TMV) ......................................................................... 13

2.5 Controle biológico por antibiose ........................................................................ 13

2.6 Indução de resistência a fitopatógenos .................................................................. 16

2.6.1 Mecanismos de resistência ........................................................................ 18

2.6.2 Indução de resistência por fungos ................................................................... 20

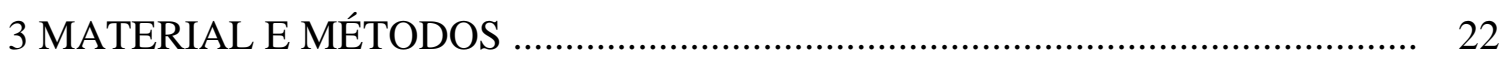

3.1 Isolados de L. edodes .............................................................................. 22

3.2 Obtenção dos preparados a partir de L. edodes ....................................................... 23

3.3 Obtenção e manutenção dos fitopatógenos ............................................................ 23

3.4 Efeito de L. edodes sobre Colletotrichum sublineolum ......................................... 25

3.4.1 Efeito dos extratos aquosos de basidiocarpos de L. edodes na germinação de conídios e na formação de apressórios por C. sublineolim 
3.4.2 Efeito de extratos aquosos de basidiocarpos de L. edodes sobre o crescimento micelial de C. sublineolum em meio de cultivo

3.4.3 Efeito de substâncias voláteis de $L$. edodes no crescimento micelial de $C$. sublineolum

3.5 Efeito de L. edodes sobre Alternaria solani

3.5.1 Efeito dos extratos aquosos de basidiocarpos de L. edodes na germinação de conídios de A. solani

3.5.2 Efeito de extratos aquosos de $L$. edodes sobre o crescimento micelial de $A$. solani em meio de cultivo

3.6 Efeito de L. edodes sobre Xanthomonas axonopodis pv. passiflorae

3.6.1 Efeito dos extratos aquosos de basidiocarpos e dos filtrados do crescimento micelial de $L$. edodes na multiplicação de $X$. axonopodis pv. passiflorae

3.6.2 Efeito da autoclavagem de extratos aquosos de L. edodes na multiplicação de X. axonopodis pv. passiflorae

3.7 Efeito de L. edodes sobre Tobacco mosaic virus (TMV)

3.7.1 Efeito de extratos aquosos de basidiocarpos de L. edodes na infectividade do TMV

3.7.2 Efeito da autoclavagem de extratos aquosos de L. edodes na infectividade do TMV

3.8 Separação dos compostos do extrato aquoso de basidiocarpos do isolado LE 96/22 de L. edodes através de cromatografia de troca aniônica (CTA)

3.8.1 Efeito dos picos (frações agrupadas) de L. edodes no crescimento micelial de C. sublineolum e de A. solani

3.8.2 Efeito dos picos (frações agrupadas) de L. edodes na germinação de conídios e formação de apressórios por $C$. sublineolum e na germinação de conídios de $A$. solani

3.8.3 Efeito dos picos (frações agrupadas) de L. edodes na multiplicação de $X$. axonopodis pv. passiflorae

3.8.4 Efeito dos picos (frações agrupadas) de L. edodes sobre o TMV em plantas de fumo 
3.8.5 Determinação da concentração de proteínas e carboidratos no extrato aquoso de basidiocarpos e nos picos (frações agrupadas) de L. edodes

4 RESULTADOS

4.1 Efeito dos extratos aquosos de basidiocarpos de $L$. edodes na germinação de conídios, na formação de apressórios e no crescimento micelial de $C$. sublineolum

4.2 Efeito de substâncias voláteis produzidas pelo micélio de L. edodes sobre o crescimento micelial de $C$. sublineolum

4.3 Efeito dos extratos aquosos de $L$. edodes na germinação de conídios e no crescimento micelial de A. solani

4.4 Efeito de substâncias voláteis produzidas pelo micélio de L. edodes sobre o crescimento micelial de $A$. solani

4.5 Efeito dos extratos aquosos de diferentes isolados de L. edodes na multiplicação in vitro de $X$. axonopodis pv. passiflorae

4.6 Efeito dos extratos aquosos de basidiocarpos de $L$. edodes na infectividade do Tobacco mosaic virus (TMV)

4.7 Separação dos compostos de L. edodes por cromatografia de troca aniônica e o efeito in vitro sobre os fitopatógenos

4.7.1 Efeito na germinação de conídios, formação de apressórios e crescimento micelial de $C$. sublineolum 47

4.7.2 Efeito na germinação de conídios e no crescimento micelial de A. solani .......... 50

4.7.3 Efeito na multiplicação in vitro de $X$. axonopodis pv. passiflorae .

4.8 Separação dos compostos do extrato de basidiocarpos de L. edodes, utilizando CTA, com atividade inibitória à infectividade do TMV 52

4.8.1 Efeito das frações de L. edodes sobre a infectividade do TMV 55

5 DISCUSSÃO 59

5.1 Efeito de extratos aquosos de L. edodes sobre C. sublineolum

5.2 Efeito de substâncias voláteis de $L$. edodes no crescimento micelial de $C$. sublineolum 60

5.3 Efeito de L. edodes sobre A. solani 
5.4 Efeito de $L$. edodes sobre o crescimento de $X$. axonopodis pv. passiflorae .......... 62

5.5 Efeito dos extratos aquosos na infectividade do TMV em fumo ......................... 63

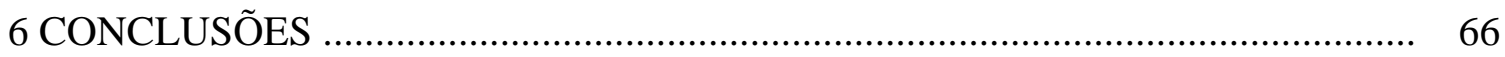

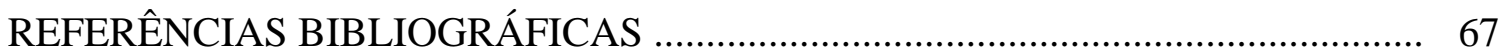

APÊNDICE 


\title{
EFEITO DE EXTRATOS AQUOSOS DO BASIDIOCARPO E MICÉLIO DE Lentinula edodes (SHITTAKE) SOBRE Colletotrichum sublineolum, Alternaria solani, Xanthomonas axonopodis pv. passiflorae e Tobacco mosaic virus (TMV)
}

\author{
Autor: NÍVEA MARIA TONUCCI \\ Orientador: Prof. Dr. SÉRGIO FLORENTINO PASCHOLATI
}

\section{RESUMO}

Lentinula edodes é um cogumelo comestível que possui qualidades nutricionais, terapêuticas e medicinais. Além disso, muitos estudos na área médica têm comprovado que o cogumelo possui efeito antibiótico sobre microrganismos patogênicos ao homem. Na área agrícola, alguns trabalhos realizados com o cogumelo demonstraram possíveis efeitos no controle de fitopatógenos. O presente trabalho teve como objetivo demonstrar a produção de substâncias antimicrobianas por L. edodes ativas sobre Colletotrichum sublineolum, agente causal da antracnose em sorgo, Alternaria solani, responsável pela pinta preta do tomateiro, Xanthomonas axonopodis pv. passiflorae, agente causal da mancha bacteriana em maracujazeiro e Tobacco mosaic virus (TMV), causador de mosaico foliar em fumo. Para os testes com C. sublineolum e A. solani foram utilizados extratos aquosos de L. edodes, obtidos a partir de basidiocarpos desidratados em pó, dos isolados LE JAB-K, LE 96/22, LE 96/17 e LE 95/01. Os resultados evidenciaram que o extrato aquoso de basidiocarpos do isolado LE 96/22 inibiu o crescimento micelial in vitro e a formação de apressórios por C. sublineolum. Já os extratos dos isolados LE JAB-K e LE 95/01 apresentaram efeito inibitório na germinação de conídios e na 
formação de apressórios do patógeno. Em contrapartida, os extratos aquosos de basidiocarpos dos diferentes isolados de L. edodes não apresentaram efeito inibitório na germinação dos conídios e no crescimento micelial de A. solani. Por sua vez, os extratos aquosos de basidiocarpos a $20 \%(\mathrm{v} / \mathrm{v})$ e o filtrado do crescimento micelial de $L$. edodes, misturados à suspensão de $X$. axonopodis pv. passiflorae, exibiram redução na multiplicação bacteriana. Todos os extratos aquosos de basidiocarpos dos diferentes isolados testados na multiplicação da bactéria mostraram-se termolábeis, quando autoclavados a $121{ }^{\circ} \mathrm{C}$ por $20 \mathrm{~min}$. Em experimentos com plantas de fumo, os extratos aquosos de basidiocarpos dos isolados LE 96/17 e LE 96/22 adicionados à suspensão contendo partículas do TMV reduziram significativamente a ocorrência de lesões locais nas folhas. O extrato aquoso do isolado LE 96/22 apresentou compostos antivirais de natureza termoestável. Finalmente, o extrato aquoso de basidiocarpos do isolado LE 96/22, o qual apresentou a maior atividade antimicrobiana, foi purificado parcialmente por cromatografia de troca aniônica (CTA). O pico V apresentou efeito inibitório no crescimento micelial de $C$. sublineolum. Por sua vez, a multiplicação de $X$. axonopodis pv. passiflorae foi inibida pelos picos IV, V e VII. Já os picos I, II e III, obtidos em CTA por gradiente linear de $\mathrm{NaCl}$ e o pico I obtido em CTA pelo método "step wise", reduziram significativamente a infectividade do TMV em plantas de fumo. Com base nesses resultados, evidencia-se a ação de preparações de L. edodes sobre fitopatógenos, o que demonstra o uso potencial do mesmo no controle de agentes causais de doenças infecciosas em plantas. 


\title{
EFFECT OF AQUEOUS EXTRACTS FROM MYCELIUM AND BASIDIOCARPS OF Lentinula edodes (Shiitake) on Colletotrichum sublineolum, Alternaria solani, Xanthomonas axonopodis pv. passiflorae and Tobacco mosaic virus (TMV)
}

\author{
Author: NÍVEA MARIA TONUCCI \\ Adviser: Prof. Dr. SÉRGIO FLORENTINO PASCHOLATI
}

\section{SUMMARY}

Lentinula edodes is an edible mushroom that has nutritious, therapeutical and medicinal qualities. Moreover, many studies in the medical area have shown that the mushroom exhibits antibiotic effects on pathogenic microorganism to the man. In the agricultural area, work carried out with the mushroom has demonstrated its possible effects to control phytopathogens. The objective of the present work was to demonstrate the productionof antimicrobial substances of $L$. edodes active on Colletotrichum sublineolum, causal agent of anthracnose in sorghum, Alternaria solani, responsible for the black spot of the tomato plants, $X$. axonopodis pv. passiflorae, causal agent of the bacterial spot in passion fruit plants and on Tobacco mosaic virus, causal agent of the mosaic in tobacco plants. For the test with $C$. sublineolum and A. solani aqueous extracts were obtained from dehydrated fruiting bodies from the shiitake isolates LE JAB-K, LE 96/22, LE 96/17 and LE 95/01. The results showed that the fruiting body aqueous extract from isolate LE 96/22 inhibited micelial growth and appressorium formation by C. sublineolum. The aqueous extracts of isolates LE JAB-K and LE 95/01 exhibited 
inhibitory effect on conidium germination and on formation of appressorium by the patogen. On the other hand, the extracts of the different isolates of $L$. edodes did not exhibit inhibitory effect on conidium germination and micelial growth of $A$. solani. The aqueous extracts of fruiting bodies at $20 \%(\mathrm{v} / \mathrm{v})$ concentration and filtrate of the micelial growth of L. edodes, when mixed to the suspension of $X$. axonopodis pv. passiflorae, exhibited decreased on bacterial multiplication. All the aqueous extracts of fruiting bodies tested from the different isolates in the bacterial multiplication were thermobile, when heated at $121{ }^{\circ} \mathrm{C}$ for $20 \mathrm{~min}$. In experiments with tobacco plants, the aqueous extracts of fruiting bodies of isolates LE 96/17 and LE 96/22 when added to the suspension of TMV reduced the amount of local lesions on the leaves. When the aqueous extracts of LE 96/22 were heated the antiviral nature was not lost. Finally, the aqueous extract of fruiting bodies from isolate LE 96/22 that presented major antimicrobial activity was partially purified by anion exchange chromatography (AEC). The peak $\mathrm{V}$ exhibited inhibitory effect on micelial growth of $C$. sublineolum. Multiplication of $X$. axonopodis pv. passiflorae was inhibited by peaks IV, V and VII. Regarding TMV infectivity, peaks I, II and III, obtained in CTA through linear gradient of $\mathrm{NaCl}$, and peak I also obtained through CTA by the method "step wise", significantly reduced virus infectivity in tobacco plants. Based upon these results, it is shown that preparations of $L$. edodes can interfere whith phytopathogen multiplication, demonstrating its potential to control plant diseases. 


\section{INTRODUÇÃO}

Os cogumelos são considerados um grupo especial de fungos pelo seu tamanho macroscópico, por ser constituído de corpos de frutificação denominados basidiocarpos e por produzirem esporos. Existem na natureza mais de 250.000 espécies de fungos, sendo que destes, 10.000 espécies são representadas pelos cogumelos, os quais podem ser comestíveis ou venenosos (Chang, 1991).

A grande quantidade de espécies de basidiomicetos existentes na natureza e que constituem fontes naturais de metabólitos biologicamente ativos, tem motivado nas últimas décadas o interesse em estudar esses organismos. Diversas moléculas presentes nos basidiomicetos apresentam atividades antitumoral, antimutagênica, imunológica, antimicrobiana, enzimática, entre outras.

Lentinula edodes (shiitake) é um fungo aeróbio, saprófitico capaz de degradar compostos como lignina, celulose e hemicelulose através da atividade de enzimas oxidativas e hidrolíticas. Lacases e peroxidases dependentes de manganês (II) pertencem ao grupo de enzimas responsáveis pela degradação de lignina (Leatham, 1985). Enzimas sintetizadas por L. edodes podem atuar na degradação de poluentes do ambiente. Makkar et al. (2001) identificaram um complexo de proteínas multicomponentes (peroxidases dependente de manganês (II), lacase e $\beta-1,3$ glucosidase) no extrato do micélio de $L$. edodes capaz de degradar pentaclorofenol e 2,5-diclorofenol.

O cogumelo shitake é principalmente conhecido por exibir qualidades nutricionais, terapêuticas e medicinais. É considerado excelente fonte de alimento devido ao seu valor nutricional (Crisan \& Sands, 1978). Além disso, estudos na área médica já comprovaram que o shiitake produz compostos com ação antitrombótica, hipocolesterolêmica, imunopotenciadora, antifúngica, antibacteriana e antiviral (Jong \& Birmingham, 1993). 
Segundo Lobanok et al. (2003), o micélio obtido por cultivo submerso e o corpo de frutificação de $L$. edodes contêm quantidades significativas de substâncias biologicamente ativas com atividade imunomodulatória.

$\mathrm{Na}$ área agrícola, os trabalhos realizados com $L$. edodes demonstram possíveis efeitos contra patógenos de plantas. Pacumbaba et al. (1999) verificaram que o lixiviado do micélio do shiitake apresentou atividade inibitória sobre várias espécies de bactérias fitopatogências como Pseudomonas syringae pv. glycinea, P. syringae pv. tabaci, Xanthomonas campestris pv. glycines, Erwinia amylovora entre outras. Por sua vez, extratos aquosos de basidiocarpos do shiitake foram eficientes no controle de algumas doenças de interesse econômico (Piccinin, 2000; Di Piero \& Pascholati, 2004).

Dessa maneira, o objetivo do trabalho foi demonstrar a produção de substâncias antimicrobianas pelo shiitake atuando contra microrganismos fitopatogênicos como $C$. sublineolum, agente causal da antracnose em cultura de sorgo, A. solani, responsável pela pinta preta do tomateiro, X. axonopodis pv. passiflorae, agente causal da mancha bacteriana do maracujazeiro e Tobacco mosaic virus (TMV), causador de mosaico em plantas de fumo. 


\section{REVISÃO DE LITERATURA}

\subsection{O cogumelo shiitake (Lentinula edodes)}

Lentinula edodes (Berk.) Pegler, também conhecido como shiitake, pertence à classe dos basidiomicetos (Chang \& Miles, 1989). É um fungo aeróbio, saprófitico, que coloniza madeira de várias espécies (Figura 1). Possui micélio septado, reproduz-se sexuadamente por intermédio de esporos exógenos (basidiósporos) ou assexuadamente (reprodução vegetativa) pela fragmentação do micélio. Estruturas especiais denominadas de grampos de conexão são formadas no micélio vegetativo para manter a condição dicariótica (Alexopoulos et al., 1996).

O interesse pelo cultivo e consumo do cogumelo shiitake é atribuído às suas qualidades gastronômicas, nutricionais e medicinais, tornando-o atualmente o segundo cogumelo mais consumido no mundo (San Antonio, 1981; Przybylowicz \& Donoghue, 1990). É conhecido há aproximadamente 1.000 anos nos países asiáticos e nos de origem do cogumelo (Singer, 1961; Przybylowicz \& Donoghue, 1990).

Segundo Przybylowicz \& Donoghue (1990), o cultivo de shiitake originou-se na China durante a dinastia Sung (960-1127), sendo introduzido no Japão por intermédio de cultivadores chineses. Posteriormente, o cultivo foi introduzido nos EUA e Europa (Royse et al., 1985; Sabota, 1996). No Brasil, foi introduzido comercialmente no início da década de 90 (Pascholati et al., 1998), sendo que a produção anual do cogumelo fresco está em torno de 200 t (Ferreira, 1998).

L. edodes apresenta em sua composição 85-95\% de água, proteínas (10-17\% da matéria seca) e inclui todos os aminoácidos essenciais ao homem abrangendo de 25-40\% do total de aminoácidos (Przybylowicz \& Donoghue, 1990). Embora possua todos os 
aminoácidos essenciais, L. edodes apresenta quantidades restritas de metionina, cistina, valina, e isoleucina (Crisan \& Sands, 1978). O cogumelo também possui 83\% de carboidrato total (matéria seca), dos quais 13\% são fibras (Breene, 1990).

A importância dos cogumelos na alimentação humana é devida à alta qualidade das proteínas encontradas na sua composição, aos carboidratos e às fibras dietéticas, às pequenas quantidades de lipídeos e à prevalência de ácidos graxos insaturados, vitaminas e minerais (Breene, 1990).

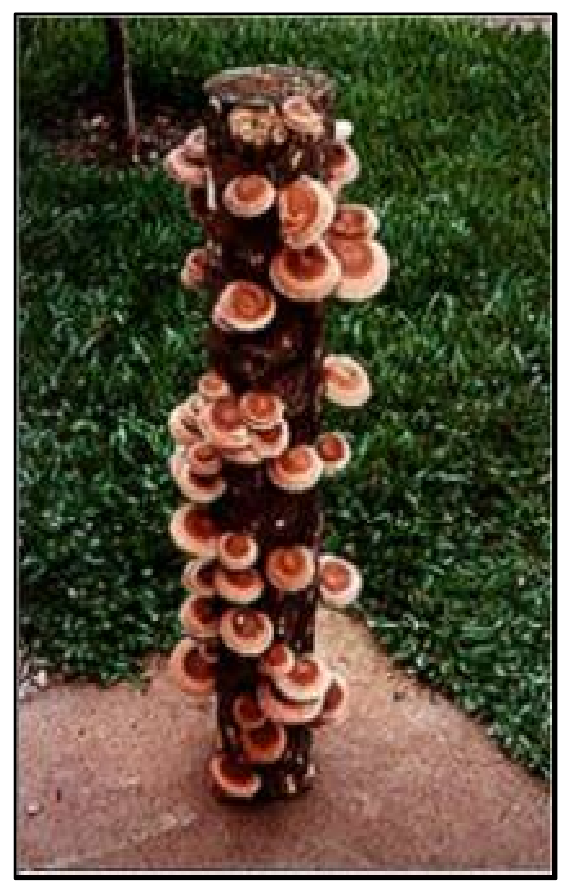

Figura 1- Basidiocarpos de Lentinula edodes (cogumelo shiitake) produzidos em tora de eucalipto

\subsection{Valor terapêutico e medicinal de $L$. edodes}

Desde os tempos mais remotos na história da humanidade, várias espécies de cogumelos têm sido utilizadas como medicamento para o combate ou prevenção de alguns males tais como câncer, doenças do coração e doenças causadas por infecções virais. Compostos com atividade antitumoral dos cogumelos podem variar quanto à 
natureza química, incluindo polissacarídeos, proteínas, glicoproteínas, ácidos nucléicos e lipídeos (Breene, 1990).

Polissacarídeos extraídos do cogumelo não apresentaram efeito direto sobre as células tumorais, mas proporcionaram efeito antitumoral por ativação da resposta imunomodulatória do hospedeiro. Atribui-se a esta resposta, o aumento da atividade de macrófagos. Macrófagos são um tipo de células brancas do sangue que destroem patógenos como bactérias, levedura e células infectadas por vírus (Wasser \& Weis, 1999).

Chihara et al. (1969) isolaram, a partir de extrato aquoso do corpo de frutificação de L. edodes, um polissacarídeo de configuração atômica helicoidal, com alta massa molecular, solúvel em água e formado por $\beta$-D $(1 \rightarrow 3)$ glucana, o qual foi chamado de lentinana. Tal composto inibiu o crescimento de Sarcoma 180 implantado em ratos. A lentinana não é tóxica para células tumorais, mas inibe o crescimento do tumor pela ativação do sistema imune, ou seja, a $\beta$-D-glucana liga-se à superfície de linfócitos ou a proteínas específicas do soro, ativando macrófagos, células T-helper e célula natural killer, resultando no aumento da produção de anticorpos, interleucinas e interferon (Mizuno, 1995 a).

Outro polissacarídeo, obtido a partir do micélio de L. edodes, consiste em um $\alpha$ mananapeptídeo denominado KS-2, composto principalmente pelos aminoácidos serina, treonina, alanina e prolina. KS-2 apresenta atividade antitumoral em ratos concomitante à indução de interferon e ativação de macrófagos (Suzuki et al., 1979).

Uma glicoproteína, denominada LEM (“Lentinula edodes mycelia”), constituída por galactose, xilose, arabinose, vitaminas do complexo B e ergosterol, foi extraída após a maceração do micélio do shiitake junto com o meio sólido no qual o fungo cresceu vegetativamente por 3 a 4 meses a $22^{\circ} \mathrm{C}$. O macerado foi incubado por $60 \mathrm{~h}$ a $50{ }^{\circ} \mathrm{C}$ na presença de enzimas de ocorrência natural no micélio e o resíduo foi extraído com água $\left(60{ }^{\circ} \mathrm{C}\right)$ e liofilizado. Compostos do LEM e duas frações extraídas do mesmo, denominadas LAP e EP3, apresentaram atividade anticarcinogênica em animais e humanos, ativando o sistema imune do hospedeiro (Sugano et al., 1982). O LAP é um precipitado obtido a partir de uma solução aquosa de LEM pela adição de quatro 
volumes de etanol, enquanto EP3 trata-se de um complexo composto por $80 \%$ de lignina, 10\% de carboidratos, 10\% de proteínas. A substância ativa do EP3 é uma lignina solúvel em água constituída de grupos carboxil (Suzuki et al., 1990).

A eritadenina, derivado da adenina foi obtida a partir do extrato etanólico (80\%) de basidiocarpo e apresenta efeito hipocolesterolêmico. Tal efeito não inibe a biossíntese de colesterol, mas acelera a excreção do colesterol ingerido e a decomposição dos seus metabólicos (Mizuno, 1995a).

\subsection{Atividade antimicrobiana de $L$. edodes}

Diversos estudos comprovaram que L. edodes possui compostos com atividade antibiótica atuando sobre microrganismos de natureza fúngica, bacteriana e viral.

Albino (1996) estudou a interação de L. edodes com fungos contaminantes da cultura de cogumelo in vitro e concluiu que o cogumelo apresentou antagonismo a quatro fungos dos cinco contaminantes. Por sua vez, Sasaki et al. (2001) observaram que o filtrado da cultura de L. edodes proporcionou efeito inibitório sobre os fungos fitopatogênicos Helminthosporium spp. e Helminthosporium euphorbiae. Enquanto que Maki (1999) verificou atividade fungistática de L. edodes sobre Candida albicans, a qual foi dependente do tempo e das condições de desenvolvimento do micélio.

Extratos aquosos das partes individualizadas do basidiocarpo (píleo e estipe), em concentrações superiores a 1\% (v/v), apresentaram efeito inibitório no crescimento micelial e na esporulação de Exserohilum turcicum, e no desenvolvimento micelial de $C$. sublineolum (Piccinin, 2000).

Uma substância com atividade antimicrobiana, isolada de $L$. edodes, conhecida como cortinelina propiciou atividade antibiótica contra Candida albicans, Staphylococcus aureus e Bacillus subtilis (Bianco, 1981). Outra substância proveniente da cultura líquida do crescimento micelial de L. edodes apresentou atividade inibitória contra Streptococcus pyogenes, Staphylococcus aureus, Bacillus megaterium e Candida albicans (Hatvani, 2001). 
Ishikawa et al. (2001) constataram a presença de substâncias com alto efeito inibitório no filtrado da cultura do micélio e no extrato de micélio de L. edodes a Bacillus subtilis. O isolado LE 1 foi o que proporcionou a maior inibição. O isolado também inibiu o crescimento de bactérias patogênicas e deterioradoras de alimentos, especialmente as gram-positivas.

Jong \& Birmingham (1993) citam que a lentinana, substância isolada do extrato aquoso do corpo de frutificação do cogumelo, apresenta atividade antibacteriana contra Escherichia coli, Pseudomonas aureaginosa e Klesbsiella pnemonia, além de efeito antifúngico para C. albicans.

Filtrados da cultura de $L$. edodes apresentaram atividade antibacteriana contra Bacillus, Listeria, Staphylococcus, Acinetobacter, Salmonella, Serratia, Enterobacter, Escherichia, Klebsiella, Proteus, Pseudomonas, Shigella e Yersinia, porém os filtrados proporcionaram melhor controle de bactérias do tipo gram positivas (Ishikawa, 1997). Piccinin (2000) também observou que os extratos aquosos de basidiocarpos, de píleo e de estipe reduziram a multiplicação de Xanthomonas axonopodis pv. passiflorae. Porém, o efeito do primeiro extrato foi do tipo bacteriostático enquanto o último apresentou efeito bactericida.

Compostos antivirais também são produzidos por L. edodes. Uma fração protéica isolada de cogumelo shiitake, denominada FBP (Fruiting Body Protein), previne a infecção de plantas contra TMV (Przybylowicz \& Donoghue, 1990). Por sua vez, Sasaki et al. (2001) observou atividade inibitória dos extratos miceliais de L. edodes sobre o vírus da estomatite vesicular de eqüinos (VSA), em cultura de células Vera. Di Piero (2003) observou que a mistura dos extratos aquosos de basidiocarpos dos isolados LE 96/17 e LE 96/22 de L. edodes à suspensão viral de Passion fruit woodiness virus (PWV) inibiram a infectividade do vírus em folhas de Chenopodium quinoa. Breene (1990) também comenta sobre outros trabalhos na literatura envolvendo o efeito antiviral de L. edodes sobre os vírus da influenza, da poliomielite, ortomixovírus e vírus da encefalite eqüina. 


\subsection{Fitopatógenos utilizados no estudo}

\subsubsection{Colletotrichum sublineolum}

C. sublineolum (Henn Kabat et Bub.) é o agente causal da antracnose, considerada a principal doença do sorgo no Brasil, sendo uma das mais importantes doenças dessa gramínea em todas as regiões produtoras no mundo (Frederiksen, 1991). Isolados de Colletotrichum em milho e sorgo foram diferenciados entre C. graminicola e $C$. sublineolum baseando-se nas diferenças morfológicas de estruturas fúngicas e mais recentemente através de métodos moleculares (Sutton; Vaillancourt \& Hanau, citados por Browning et al.,1999).

Os conídios de C. sublineolum são produzidos em acérvulos e apresentam-se aglutinados numa massa gelatinosa, que dissolve em água (Figura 2). Os conidióforos são eretos, hialinos, não-septados e curtos. Conídios formam-se terminalmente nos conidióforos, entre as setas. São hialinos não septados e falciformes quando maduros (Figura 3). Peritécios de Glomerella graminicola, a forma sexuada do fungo, raramente são observados na natureza. Os ascos são cilíndricos a clavados tendo um poro no ápice. Os ascósporos são hialinos, unicelulares, curvos e afilados nos pólos. O fungo sobrevive em restos de cultura de sorgo e também em sementes, localizando-se freqüentemente no pericarpo, ocasionalmente no endosperma e raramente no embrião. A disseminação do patógeno dá-se principalmente por respingos de água e por sementes (Panizzi \& Fernandes, 1997).

O patógeno caracteriza-se por afetar folhas, caule, haste floral, flores e sementes de sorgo em qualquer idade. Os sintomas em folhas se iniciam por pequenas lesões circulares ou elípiticas de coloração arroxeada e que, com a evolução da doença, coalescem tomando grandes áreas do limbo foliar (Frederiksen, 1991).

Wharton et al. (2001) verificaram que eventos iniciais de infecção e penetração por C. sublineolum em cultivares de sorgo (Sorghum bicolor) resistente ou suscetível foram similares. Após $42 \mathrm{~h}$ da inoculação, os autores observaram a germinação de conídios, a produção do tubo germinativo e a formação e melanização do apressório em 
ambas cultivares. Entretanto, nas interações compatíveis, após a formação do apressório, ocorreu a formação de uma hifa de infecção, a qual invadiu o lúmen da célula epidérmica do hospedeiro e prolongou-se para a formação da vesícula de infecção e da hifa primária. Por sua vez, nas interações incompatíveis, foi observada no local de infeç̧ão, a formação de papilas, as quais restringiram o desenvolvimento de $C$. sublineolum.

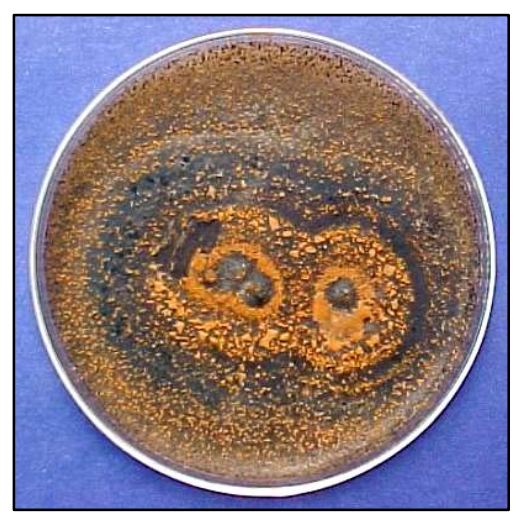

Figura 2 - Colônias de Colletotrichum sublineolum com 23 dias em meio de aveia, mantidas a $25^{\circ} \mathrm{C}$, sob luz NUV constante

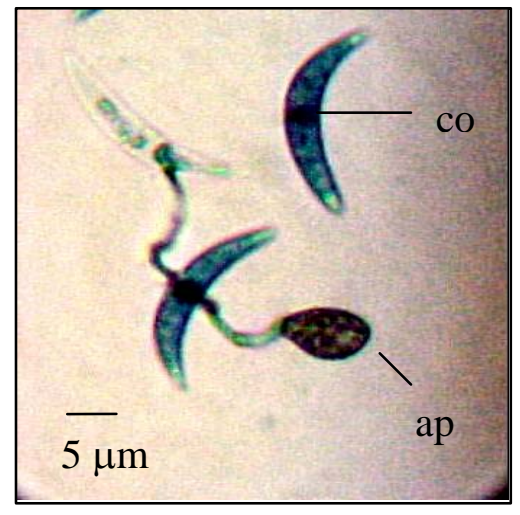

Figura 3 - Conídios (co) e apressório (ap) de Colletotrichum sublineolum 


\subsubsection{Alternaria solani}

Alternaria solani (Ell. \& G. Martin) é o fungo causador da doença conhecida como pinta preta ou mancha de Alternaria. É uma das principais doenças das culturas de batata e tomate (Kurozawa \& Pavan, 1997). O fungo se desenvolve principalmente em condições de alta umidade e temperatura entre 25 e $30{ }^{\circ} \mathrm{C}$. Possui micélio septado e ramificado, tornando-se escuro com a idade em meio de cultura (Figura 4). Os conidióforos são simples, septados, longos, sub-hialinos a escuros, com conídios terminais. Estes são multicelulares, com septos transversais e longitudinais, clavados, com uma das extremidades pontiagudas, com ou sem apêndice (Figura 5) (Kurozawa \& Pavan, 1997).

Stevenson \& Pennypacker (1988) estudaram os efeitos da radiação ultravioleta, temperatura e umidade sobre a germinação de conídios de $A$. solani. Os autores verificaram que os conídios expostos à radiação em comprimentos de onda entre $300 \mathrm{a}$ $500 \mathrm{~nm}$ não germinaram. Enquanto que, a radiação acima de $750 \mathrm{~nm}$ não inibiu o processo germinativo. Contudo, a germinação dos conídios de A. solani foi observada quando os mesmos foram mantidos no escuro à temperatura de 25 a $30{ }^{\circ} \mathrm{C}$ por 9 a $12 \mathrm{~h}$ e umidade relativa acima de $92 \%$.

Uma das características principais das espécies de Alternaria é a produção de melanina, especialmente nos esporos. Para os fungos, a melanina é um pigmento de coloração escura com alta massa molecular responsável pela proteção do patógeno em ambientes desfavoráveis. Outra característica importante da espécie é a produção de toxinas seletivas ao hospedeiro, no caso de espécies fitopatogênicas (Thomma, 2003).

A. solani pode atacar a parte aérea da planta em qualquer idade, mas as lesões são mais abundantes nas folhas mais velhas. Quando a lesão atinge a nervura da folha, esta é destruída, interrompendo a circulação da seiva e provocando o amarelecimento e morte da parte afetada. No caule, no pecíolo e na ráquis, as lesões são semelhantes às da folha, podendo provocar a morte dos mesmos (Kurozawa \& Pavan, 1997). 


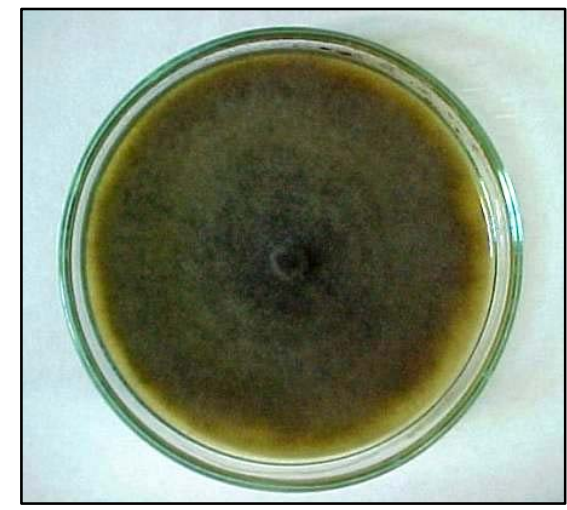

Figura 4 - Colônia de Alternaria solani com 20 dias em meio de batata-dextrose-ágar, mantido a $25{ }^{\circ} \mathrm{C}$, sob condições de luz NUV constante

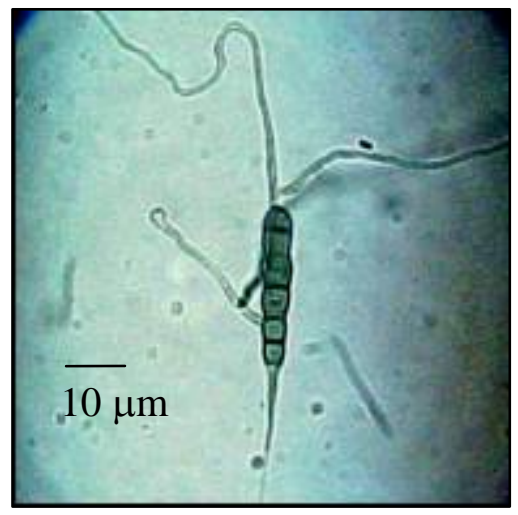

Figura 5 - Conídio germinado de Alternaria solani

\subsubsection{Xanthomonas axonopodis pv. passiflorae}

A mancha bacteriana em maracujazeiro (Passiflora spp.) é causada por $X$. axonopodis pv. passiflorae (Pereira) Dye, segundo Gonçalves \& Rosato (2000). A bactéria é gram negativa, tem a forma de bastonete, apresenta um flagelo polar para a movimentação, não produz esporos ou cápsula e mede 0,5 x 1,5 mm. Produz colônias amarelo-brilhantes, circulares, convexas e mucóides, tendo crescimento ótimo a $27^{\circ} \mathrm{C}$. 
Libera amônia, liquefaz gelatina e hidrolisa fortemente o amido. Não utiliza asparagina como fonte de carbono e nitrogênio. Utiliza citrato, galactose, frutose, manose e trealose. Não reduz nitrato nem produz indol (Pio-Ribeiro \& Mariano, 1997).

Atualmente, a mancha bacteriana é um dos principais problemas fitossanitários da cultura do maracujazeiro, ocasionando entre outros danos, a redução do período de exploração comercial da cultura (Malavolta Jr., 1998). A doença ocorre em várias regiões do Brasil como Bahia, Ceará, Distrito Federal, Espírito Santo, Minas Gerais, Paraná, Rio de Janeiro, São Paulo (Pio-Ribeiro \& Mariano, 1997) e Mato Grosso (Tassa \& Duarte, 2002).

A bactéria ataca as folhas provocando lesões pequenas, encharcadas, oleosas, translúcidas, freqüentemente localizadas próximas às nervuras tornando a área necrosada e causando seca total da folha. Nos frutos, as lesões são pardas ou esverdeadas, oleosas, circulares ou irregulares podendo penetrar até as sementes, impedindo o consumo do fruto (Pio-Ribeiro \& Mariano, 1997).

Malavolta Jr. et al. (2001) identificaram X. axonopodis pv. passiflorae em frutos de maracujazeiro-doce (Passiflorae alata Ait.). A queda dos frutos ocorria antes de atingirem o ponto de maturação. Os frutos caídos apresentavam-se íntegros externamente, sem manchas ou perfurações, porém na parte interna, o mesocarpo apresentava-se deteriorado e separado da casca. Os autores realizaram o isolamento da bactéria e através dos testes bioquímicos, fisiológicos, de hipersensibilidade, de patogenicidade e serológicos foi possível caracterizar o agente causal da doença.

Com base no polimorfosmo de DNA amplificado ao acaso (RAPD), Gonçalves \& Rosato (2000) verificaram 45\% de homologia no DNA entre os isolados de $X$. campestris e X. axonopodis, indicando que os mesmos representam espécies distintas. Por sua vez, os mesmos autores utilizaram a hibridização DNA-DNA para agrupar estirpes do patovar passiflorae. Os resultados demonstraram que as estirpes do patovar passiflorae apresentaram 54\% de homologia no DNA com relação a $X$. axonopodis e $16 \%$ de homologia com $X$. campestris. Desta forma, os autores propuseram uma nova designação para $X$. campestris pv. passiflorae, a qual foi denominada $X$. axonopodis pv. passiflorae. 


\subsubsection{Tobacco mosaic virus (TMV)}

O Tobacco mosaic virus (TMV) possui o formato alongado, é rígido, mede $300 \mathrm{x}$ 18 nm e pertence ao gênero Tobamovirus (Shew \& Lucas, 1990). O material genético é composto por RNA de fita simples (Más \& Beachy, 1999).

Estudos citológicos de células infectadas com o TMV mostraram que a replicação do vírus ocorre em inclusões citoplasmáticas, conhecidas como viroplasmas. Além da replicação, as inclusões estão associadas aos vários estágios do ciclo de multiplicação do vírus (síntese de proteínas, replicação do RNA, movimento do vírus e síntese do capsídeo) (Más \& Beachy, 1999). O RNA do TMV desalojado do capsídeo torna-se instável, no entanto, a partícula viral íntegra pode apresentar estabilidade ao calor, a enzimas e a substâncias químicas.

O vírus pode infectar as plantas em qualquer idade causando redução da área foliar, acompanhada de rugosidade e malformação das folhas, que se apresentam mais afiladas e espessas. No limbo foliar, observa-se a presença de mosaico típico, ou seja, áreas verde claras ao lado de áreas sadias. As plantas com mosaico podem apresentar o dobro de nicotina que as plantas sadias da mesma variedade (Godoy \& Salgado, 1997).

Distribuído amplamente por todas as regiões onde o fumo é cultivado, o TMV já foi relatado em 199 espécies de 30 famílias, mas as fontes de inóculo mais importantes são as solanáceas. O TMV permanece viável por muitos anos nos restos da cultura, no fumo de corda e nas sementes e pode ser transmitido por insetos e principalmente mecanicamente (tratos culturais). Desta forma, medidas de controle como rotação de cultura, desinfestação de ferramentas e cultivares resistentes podem ser utilizadas no controle da virose (Shew \& Lucas, 1990).

\subsection{Controle biológico por antibiose}

O uso de produtos químicos no controle de doenças de plantas tem ocasionado elevados prejuízos financeiros, ambientais e à saúde do homem. Desta forma, faz-se 
necessário o estudo de novas alternativas para o controle de fitopatógenos, tais como o controle biológico. Cook \& Baker (1983) definiram controle biológico de doenças de plantas como a redução do inóculo patogênico e/ ou da doença realizada por um ou mais organismos que não o homem.

A antibiose é um dos mecanismos envolvidos no controle biológico de doenças em plantas. Fravel (1988) considera a antibiose como o antagonismo mediado por metabólitos específicos ou não, de origem microbiana, agentes líticos, enzimas, compostos voláteis ou outras substâncias tóxicas. Deste modo, a antibiose consiste na produção de substâncias com efeito fungicida ou fungistático, bactericida ou bacteriostático e nematicida por organismos antagonistas, como um meio de sobrevivência diante dos demais microrganismos existentes na microbiota que ocupam (Luz, 1993).

Para Kupper et al. (2003), a produção de substâncias antifúngicas por organismos antagonistas é especialmente importante para o entendimento do mecanismo de ação de tal antagonismo, possibilitando desta forma, o controle de doenças pelo uso de substâncias produzidas e, não apenas pela introdução massal dos agentes de biocontrole.

Muitas espécies de fungos são capazes de causar antibiose a outros organismos fitopatogênicos através da síntese e da excreção de metabólitos de natureza tóxica. Deste modo, fungos antogonistas vêm sendo utilizados no controle biológico de patógenos de plantas. Lobo \& Abreu (2000) constataram a inibição in vitro do crescimento micelial de Sclerotinia sclerotiorum, isolado de plantas de feijoeiro, pela produção de metabólitos voláteis por Trichoderma viride, T. aureoviride, T. koningii, T. pseudokoningii e Penicillium sp. Por sua vez, $T$. virens tem contribuído no controle de fitopatógenos como fungos e bactérias gram-positivas pela produção de antibióticos conhecidos como “peptaibols”. Esta classe de antibióticos age inibindo enzimas associadas à membrana, as quais estão envolvidas na síntese da parede celular dos fungos (Wiest et al., 2002).

Antibióticos são metabólicos produzidos e excretados por microrganismos capazes de destruir ou inibir, em pequenas concentrações, o crescimento de outros microrganismos (Griffin, 1994). Um antibiótico conhecido como ciclosporina C, produzido pelo fungo Acremonium luzulae, apresentou atividade antifúngica sobre 
patógenos de frutas pós-colheita como Botrytis cinerea e Penicillium expansum, porém o mesmo não foi efetivo contra bactérias gram-positivas e gram-negativas (Moussaïf et al., 1997).

Compostos antibióticos produzidos por Penicillium brevicompactum (isolado MX1.L34) reduziram a germinação e o crescimento do tubo germinativo de Botrytis fabae em 79 e 29\%, respectivamente. Já o filtrado da cultura de células de Cladosporium cladosporioides (isolado MB2.F45) reduziu em 36\% o crescimento do tubo germinativo do mesmo patógeno. Frações orgânicas do filtrado da cultura de células de $P$. brevicompactum apresentaram inibição de 96 a 97\% da germinação dos conídios de $B$. fabae (Jackson et al., 1997).

Enzimas com atividade antibiótica podem ser produzidas extracelularmente ou intracelularmente por inúmeros fungos. Kim et al. (1988) identificaram uma enzima produzida por Talaromyces flavus (fase anamorfíca: Penicillium dangeardii), em meio de cultivo líquido, conhecida como glicose oxidase. Esta apresentou atividade inibitória sobre o crescimento micelial e sobre a germinação de microesclerócios de Verticillium dahlie.

Em ensaios realizados com plantas de gerânio, uma suspensão de $10^{6}$ conídios $/ \mathrm{mL}$ de $B$. cinerea foi colocada sobre a superfície foliar e, em seguida, as folhas foram tratadas com diferentes concentrações de uma proteína antifúngica $(0,1$, 1 e $10 \mu \mathrm{M})$ produzida por Aspergillus giganteus. A quantidade e o tamanho das lesões foram reduzidos de acordo com a concentração da proteína utilizada. A concentração de $10 \mu \mathrm{M}$ da proteína impediu completamente o desenvolvimento dos sintomas nas folhas. In vitro, a proteína antifúngica nas doses de 0,5 a $5 \mu \mathrm{M}$ apresentou efeito inibitório na germinação e no crescimento micelial de B. cinerea (Moreno et al. 2003). Estes resultados indicaram uma correlação dos ensaios in vitro e in vivo quanto ao potencial da atividade inibitória da proteína utilizada em baixas concentrações.

Diversos estudos têm comprovado a atividade antimicrobiana de basidiomicetos no controle de fitopatógenos. Badalyan et al. (2002) observaram a atividade antagonista in vitro de 17 espécies de cogumelos contra fungos patógenos de cereais, como Gaeumannomyces graminis var. tritici, Bipolaris sorokiniana, Fusarium culmorum e 
Rhizoctonia cerealis. Os cogumelos que apresentaram maior atividade inibitória sobre os fitopatógenos foram Polyporus varius e Polyporus subarcularius. Por sua vez, L. edodes mostrou antagonismo apenas contra Bipolaris sorokiniana.

Yohalem et al. (1996) verificaram que extratos aquosos do substrato utilizado por Agaricus bisporus inibiram in vitro a germinação de Venturis inaequalis e em vivo a infecção do mesmo em folhas de macieiras. Para o preparo dos extratos aquosos, os substratos foram coletados após o cultivo do cogumelo e então misturados com água na proporção de 1:2 (m/v). Em seguida, o material foi incubado entre 15 a $25{ }^{\circ} \mathrm{C}$ por 7 a 8 dias. Após este período, os extratos foram agitados e filtrados. Além dos compostos antifúngicos presentes nos extratos, os autores relataram também o aumento da população de microrganismos não-alvos presentes na superfície foliar da macieira, após a pulverização dos extratos nas folhas. Desta forma, os extratos aquosos dos substratos tornam-se um componente integrado na estratégia de biocontrole.

A busca de estratégias eficientes e inteligentes no combate de patógenos de plantas é uma necessidade indispensável na agricultura. Encontrar uma forma saudável e menos prejudicial ao homem e ao ambiente por certo é tema de inúmeros estudos dentro da área do controle biológico.

\subsection{Indução de resistência a fitopatógenos}

A indução de resistência é um processo, através do qual, plantas suscetíveis têm seus mecanismos latentes de defesa ativados. O fenômeno da resistência induzida a doenças pode se manifestar local ou sistematicamente, à distância do ponto de aplicação do indutor e penetração do patógeno (Pascholati \& Leite, 1995).

Estudos envolvendo indução de resistência têm investigado e demonstrado a ocorrência de dois mecanismos distintos de resposta de defesa no hospedeiro conhecidos como resistência sistêmica induzida (RSI) e resistência sistêmica adquirida (RSA).

O fenômeno da RSI envolve infecções localizadas ou tratamentos com produtos microbianos ou ainda compostos orgânicos ou inorgânicos. Por exemplo, rizobactérias 
promotoras de crescimento (Plant Growth-Promoting Rhizobacteria $=$ PGPR) usadas no controle biológico de patógenos de plantas podem também atuar como agentes de RSI promovendo resistência sistêmica generalizada. Segundo Raupach et al. (1996), plantas de pepino tratadas com PGPR e inoculadas com Cucumber mosaic virus (CMV) 14 dias após o tratamento com o indutor, não apresentaram sintomas iniciais da doença e mantiveram-se assintomáticas durante o experimento. O mesmo efeito protetor foi observado em tomateiros tratados com PGPR e inoculados posteriormente com CMV.

Segundo Chen et al. (1998), raízes de plântulas de pepino colonizadas por Pseudomonas spp. $\left(10^{8}\right.$ células $\left./ \mathrm{mL}\right)$ induziram resistência sistêmica contra a infecção causada por Pytium aphanidermatum.

A colonização de raízes de plântulas de repolho chinês pelo fungo endofítico Heteroconium chaetospira conferiu resistência sistêmica contra Pseudomonas syringae pv. maculicola e Alternaria brassicae. As plântulas foram transplantadas para solos infestados com o fungo endofítico e mantidas em câmara de crescimento por 32 dias. Após este período, as plântulas foram inoculadas separadamente com os patógenos. A incidência da doença causada por $P$. syringae foi avaliada depois de 4 dias da inoculação com a bactéria. Já a avaliação da doença causada por A. brassicae foi realizada após 7 dias da inoculação. Os resultados indicaram redução significativa na incidência das doenças em plântulas de repolho chinês colonizadas pelo fungo endofítico quando comparadas com as raízes de plântulas não colonizadas (Morita et al. 2003).

Por sua vez, Zhang et al. (2002) utilizou 5 isolados de PGPR (Serratia marcescens 90-166, Bacillus pumilus SE34, Pseudomonas fluorescens 89B-61, B. pumilus T4 e B. pasteurii C-9) para induzir resistência sistêmica em plantas de fumo contra o mofo azul causado por Penospora tabaci. Os autores verificaram que o maior efeito protetor foi dependente do isolado de PGPR utilizado no tratamento das plantas. Porém, as plantas de fumo tratadas com os isolados de PGPR apresentaram redução do mofo azul quando comparadas com as plantas não tratadas.

RSA é outro mecanismo de resposta de defesa da planta, o qual se inicia com um sinal em resposta à infecção causada por um patógeno. Este sinal é translocado para outras partes da planta induzindo reações de defesa. O ácido salicílico (AS) é 
considerado um sinal importante para o estabelecimento de RSA, pois há inúmeros estudos envolvendo o papel do AS na ativação do RSA (Métraux, 2001). Segundo Willits \& Ryals (1998), vários trabalhos têm sugerido a síntese de AS no local do tecido necrosado pelo patógeno e o seu deslocamento até as folhas não infectadas para induzir resistência. Os mesmos autores observaram em folhas de fumos inoculadas com concentrações crescentes de TMV, um aumento linear do nível de AS.

Burketová et al. (2003) observaram a ativação de RSA em plantas de beterraba por dois indutores, um sintético, o benzothiadiazole (BTH) e outro biótico, o Beet necrotic yellow vein virus. Ambos indutores ativaram mecanismos de defesa sistêmica nos tecido das raízes através do acúmulo de enzimas como quitinases e $\beta-1,3$ glucanases na parede celular e nos espaços extracelulares.

Segundo Moraes (1998), diversos trabalhos têm constatado os mecanismos envolvidos na ativação de RSA. Tais mecanismos envolvem a iniciação que resulta na cascata de eventos após o reconhecimento do patógeno pela planta, a transmissão de sinais que atuam ativando mecanismos de resistência na célula não diretamente infectada por patógenos e a expressão de genes de defesa da planta no local da infecção ou sistemicamente. Após a ativação de RSA, várias mudanças ocorrem na membrana plasmática da célula como alterações nas concentrações de íons de cálcio, potássio e nucleotídeos cíclicos (Dixon \& Lamb, 1990).

\subsubsection{Mecanismos de resistência}

As plantas possuem fatores estruturais e bioquímicos pré-existentes (passivos, constitutivos) que estão envolvidos no processo de resistência antes da infecção pelo patógeno como cutícula, tricomas, estômatos, fibras e vasos condutores, fenóis, alcalóides, lactonas insaturadas, glicosídeos fenólicos e cianogênicos, fototoxinas e inibidores protéicos. Após a infecção, pode aumentar o nível de compostos de defesa pré-existentes nas plantas ou ocorrer a ativação de outros mecanismos de resistência (pós-formados) que são sintetizados e acumulados nos tecidos do hospedeiro como as 
proteínas relacionadas à patogênese (proteínas-RP), fitoalexinas, calose, lignina, papilas, camadas de cortiça e tiloses (Pascholati \& Leite, 1995).

Em raízes de gerânio infectadas com Pythium ultimum foram observadas mudanças histológicas em células da endoderme, livres da infecção, como o acúmulo de material denso, grânulos escuros e distorção das células da região cortical. Por sua vez, os resultados citoquímicos mostraram que a parede celular das raízes não foi alterada com relação à quantidade de pectina e celulose (Desilets et al.,1994).

Estudos histológicos revelaram que Pinus banksianas naturalmente infectados por Gremmeniella abietina exibiram a formação de uma barreira ligno-suberizada que restringiu o fungo às áreas necróticas. O fungo penetra pelos estômatos, invade o córtex do caule e células do floema chegando ao câmbio vascular (Simard et al., 2001).

As peroxidases, enzimas antioxidantes, estão envolvidas na lignificação das células de plantas em resposta a infecções por patógenos (Mander \& Fussi, 1982). Segundo Koike et al. (2001), o aumento da deposição de lignina ocorreu em tecidos foliares de plântulas de pepino pré-tratados com o filtrado da cultura de fungos promotores de crescimento de plantas (Trichoderma sp., Fusarium sp., Penicillium sp., Phoma sp.) contra Colletotrichum orbiculare. Os autores verificaram também que fungos promotores de crescimento de plantas e o filtrado dos mesmos levaram à produção de superóxido em plantas de fumo. O superóxido é uma das espécies ativas de oxigênio gerado a partir da explosão oxidativa, poucos minutos após o tratamento do tecido foliar ou da cultura de células vegetais com bactérias, fungos, componentes da parede celular fúngica ou elicitores abióticos. Estas espécies de oxigênio podem agir diretamente sobre os patógenos durante as etapas iniciais da infecção (Sutherland, 1991).

Ghaouth et al. (2003) observaram que pêssegos tratados com radiação UV-C induziram o aumento de proteínas relacionadas à patogênese (quitinases, $\beta-1,3$ glucanases) e fenilalanina amônia-liase (FAL), após 6 h do tratamento. A enzima FAL é importante na via que induz a síntese de fenóis, fitoalexinas e lignina, os quais estão associados ao processo de resistência localizada (Ryalls, 1996). Solórzano et al. (1996) verificaram o aumento da atividade de $\beta-1,3$ glucanases em plantas de tomate após a inoculação com A. solani. 
As fitoalexinas, compostos antimicrobianos de baixa massa molecular, são sintetizadas por plantas em resposta à infecção ou estresse (Smith, 1996). Lopez \& Pascholati (1992) verificaram o acúmulo de um complexo de pigmentos em mesocótilos de sorgo após a injúria ou inoculação dos mesmos com C. graminicola.

Lo et al. (1999) observaram o acúmulo de quatro fitoalexinas (luteolinidina, metoxiluteolinidina, e éster do ácido caféico-arabinosi 5-O-apigeninidina e apigeninidina) nas interações incompatíveis utilizando cultivares resistentes de plantas de sorgo inoculadas com C. sublineolum, enquanto que nas interações compatíveis em cultivares resistentes inoculados com o mesmo fungo houve o acúmulo de duas fitoalexinas (apigeninidina e éster do ácido caféico-arabinosi 5-O-apigeninidina). A fitoalexina metoxiluteolinidina apresentou efeito fungitóxico sobre a germinação de conídios e na formação de apressórios de C. sublineolum (Lo et al., 1996).

\subsubsection{Indução de resistência por fungos}

Espécies de fungos patogênicos ou não patogênicos, bem como moléculas de origem fúngica como oligopeptídeos, carboidratos, glicoproteínas ou ergosterol podem induzir reações de defesa em plantas contra diversas doenças (Oku, 1994).

A aspersão prévea de Saccharomyces cerevisiae em plântulas de milho pipoca suscetíveis à Exserohilum turcicum reduziu o tamanho e o número médio de lesões por planta. (Stangarlin \& Pascholati, 1994). S. cerevisiae possui moléculas elicitoras capazes de induzir o acúmulo de fitoalexinas em mesocótilos de sorgo (Wulff \& Pascholati, 1999) e em pepino contra C. lagenarium aumentando também a atividade de peroxidase (Labanca, 2002).

O tratamento de plântulas de feijão com espécies não patogênicas de Rhizoctonia induziu resistência contra $R$. solani e $C$. lindemuthianum reduzindo em 80 a 100\% a podridão da raiz causada por $R$. solani e 38\% a antracnose causada por C. lindemuthianum. Foi observado aumento da atividade de peroxidases, 1,3- $\beta$-glucanases e quitinases nas plântulas de feijão (Xue et al., 1998). 
Singh et al. (1999) investigaram a interação de dois isolados de Albugo candida sendo um compatível e outro incompatível a Brassica juncea. Observaram que o isolado incompatível induziu poteção local e sistêmica em cotilédones e em folhas verdadeiras contra o isolado compatível.

A colonização de raízes de plantas de aspargo (Aspagarus officinalis) por isolado não patogênico de Fusarium oxysporum induziu resistência sistêmica contra o isolado patogênico F. oxysporum f. sp. asparagi. As plantas tratadas com o isolado não patogênico apresentaram rápido aumento de atividades de peroxidases, fenilalanina amônia-liase e lignina em relação às plantas não tratadas (He et al., 2002).

Segundo Takenaka et al. (2003) frações protéicas da parede celular de Pythium oligandrum induziram resistência em plântulas de beterraba contra $R$. solani e em trigo contra Fusarium graminearum reduzindo as doenças causadas pelos respectivos patógenos. Os autores verificaram o aumento da atividade de fenilalanina amônia-liase e quitinases nas plântulas tratadas com as frações protéicas quando comparadas com plântulas tratadas com água.

Suspensões de Candida saitoana aplicadas em maçãs 48 e 72 h antes da inoculação com Botrytis cinerea reduziram em 50 e 70\% o tamanho das lesões causadas pelo patógeno. Houve aumento de atividades de $\beta-1,3$ glucanase e quitinase em maçãs após 12 h do tratamento com a levedura (Ghaouth et al. 2003).

Piccinin (2000) relatou que preparações de L. edodes induziram a produção de fitoalexinas do complexo das deoxiantocianidinas em sorgo e gliceolinas em soja. Por sua vez, o filtrado do crescimento micelial e estipe do cogumelo foram eficazes na redução de infecções locais e sistêmicas de $X$. axonopodis pv. passiflorae em maracujazeiros.

Di Piero \& Pascholati (2004a) verificaram que o extrato aquoso de Agaricus blazei (isolado 99/28) pode ter induzido resistência em tomateiro contra $X$. campestris pv. vesicatoria. As plantas tratadas com o extrato exibiram um aumento na atividade de glucanases, enquanto que a atividade de peroxidase não foi alterada. 


\section{MATERIAL E MÉTODOS}

\subsection{Isolados de L. edodes}

Os isolados de L. edodes utilizados nos experimentos foram obtidos a partir do Departamento de Produção Vegetal (Módulo de Cogumelos), da Faculdade de Ciências Agrárias/UNESP/Botucatu, sob coordenação do Prof. Dr. Augusto Ferreira da Eira e são provenientes de regiões e climas distintos. Os isolados LE JAB-K, LE 96/22, LE 96/17 e LE 95/01 são originários de Jaboticabal/SP, Botucatu/SP, Israel e Londrina/PR, respectivamente. Desta forma, é importante ressaltar que os isolados diferem entre si quanto à aparência (cor, tamanho e características texturais). Além disso, os isolados de L. edodes também mostraram diferenças através da análise do DNA e de isoenzimas (Teixeira, 2000).

Para a produção dos basidiocarpos, os isolados LE JAB-K, LE 96/22, LE 96/17 e LE 95/01 foram cultivados em toras de eucalipto da espécie Eucaliptus urophila. As etapas do cultivo do cogumelo em toras consistem na produção de inóculo (hifas) em meio sintético, escolha da madeira, inoculação, incubação (crescimento do micélio no interior da tora), choque térmico e hídrico para induzir os primórdios de basidiocarpo, colheita e processamento (Pascholati et al., 1998). No caso dos isolados LE 96/22 e LE 96/17, os basidiocarpos também foram obtidos a partir de cultivo axênico. Este tipo de cultivo utiliza sacos de polietileno de alta densidade contendo o substrato (serragem, farelo de trigo, farelo de arroz e carbonato de cálcio), o qual é esterilizado a $121{ }^{\circ} \mathrm{C}$ por 4 h. Após o resfiamento, o micélio do cogumelo é transferido para substrato, incubado a $24{ }^{\circ} \mathrm{C}$ durante 123 dias. Para a indução de primórdios utiliza-se choque térmico, seguido de embebição em água, colheita e processamento (Montini, 2001). 


\subsection{Obtenção dos preparados a partir de $L$. edodes}

Os preparados foram obtidos a partir do micélio e dos basidiocarpos de L. edodes. No caso do micélio, doze discos ( $0,5 \mathrm{~cm}$ de diâmetro) foram retirados do meio de cultivo BDA (batata-dextrose-ágar) contendo crescimento micelial de L. edodes e colocados em erlenmeyers com $300 \mathrm{~mL}$ de meio líquido BD (batata-dextrose). Após 30, 60 e 120 dias de cultivo, no escuro a $24{ }^{\circ} \mathrm{C}$, o conteúdo dos erlenmeyers foi filtrado em papel de filtro GF/A, seguido de filtração em membrana tipo Millipore (0,2 $\mu$ m diâmetro do poro) para a obtenção do "filtrado do crescimento micelial”.

Para a obtenção dos extratos aquosos de basidiocarpos de L. edodes, os basidiocarpos desidratados em pó receberam água destilada na proporção de 1 grama de pó de basidiocarpos para $14 \mathrm{~mL}$ de água destilada e foram incubados a $4{ }^{\circ} \mathrm{C}$ por $24 \mathrm{~h}$. Em seguida, a filtragem inicial do material foi efetuada em filtro de papel comum, e o extrato obtido foi centrifugado $\left(20.000 \mathrm{~g} / 25 \mathrm{~min}\right.$ a $\left.4{ }^{\circ} \mathrm{C}\right)$. O sobrenadante foi coletado e filtrado através de filtro Whatman GF /A. Após esta etapa, o extrato foi esterilizado em sistema Millipore (filtro de $0,2 \mu \mathrm{m}$ ), sendo armazenado a $5{ }^{\circ} \mathrm{C}$ até o momento do uso.

\subsection{Obtenção e manutenção dos fitopatógenos}

Colletotrichum sublineolum: o fungo foi isolado a partir de folhas de sorgo sintomáticas. Segmentos do tecido vegetal (aproximadamente $8 \mathrm{~mm}^{2}$ ) obtidos da área de transição entre o tecido sadio e doente, foram colocados em solução de hipoclorito de sódio comercial, na diluição de três partes de água para uma parte de hipoclorito. Após 5 min, os pedaços do tecido foram lavados três vezes em água destilada para a remoção do excesso de hipoclorito. Em seguida, 5 segmentos do tecido lesionado foram colocados na superfície de meio de cultivo ágar-água em placas de Petri mantidas a $23{ }^{\circ} \mathrm{C}$, sob luz constante, durante 10 dias. Após este período, discos de micélio foram transferidos para meio de aveia-ágar, visando a obtenção de culturas puras. 
Alternaria solani: o fungo foi isolado a partir de folhas de tomateiro contendo lesões típicas do patógeno. As folhas foram segmentadas nas proximidades do tecido lesionado e colocadas em solução de hipoclorito de sódio comercial, na diluição de três partes de água para uma parte de hipoclorito. Após $5 \mathrm{~min}$, os pedaços do tecido foram lavados três vezes em água destilada para a remoção do excesso de hipoclorito. Em seguida, 5 segmentos do tecido lesionado foram colocados na superfície de meio de cultivo ágar-água em placas de Petri. As placas contendo pedaços foliares infectados pelo patógeno foram mantidas a $25^{\circ} \mathrm{C}$, no escuro, durante 7 dias. Após esse período, discos do micélio foram transferidos ao meio de cultivo BDA (batata-dextrose-ágar) em placas de Petri, as quais foram mantidas sob luz fluorescente a $20{ }^{\circ} \mathrm{C}$. Para estimular a esporulação do fungo, $5 \mathrm{~mL}$ de água destilada foram colocados sobre a superfície da colônia de A. solani em meio de cultivo, a qual foi suavemente raspada com o auxílio de uma lâmina de vidro. Em seguida, retirou-se o excesso de água da placa, sendo esta mantida semi-aberta sob luz U.V., comprimento de onda longo (NUV), por $24 \mathrm{~h}$.

Xanthomonas axonopodis pv. passiflorae: foram selecionadas folhas de maracujazeiro (Passiflora edulis f. flavicarpa) com sintomas sistêmicos característicos da bacteriose. Essas folhas foram lavadas em água corrente e secas em papel toalha, sendo as mesmas cortadas em pequenos pedaços (aproximadamente $5 \mathrm{~mm}^{2}$ ) na região de transição entre o tecido sadio e infecção sistêmica. Os pedaços foram colocados sobre lâminas de vidro para microscopia, previamente limpas com acetona e álcool, e receberam uma gota de água destilada, sendo em seguida colocados sob microscópio óptico para a observação do exsudato bacteriano. Quando o exsudato era observado, efetuava-se a maceração dos tecidos de maracujá presentes na lâmina. Com o auxílio de uma alça de platina, o macerado foliar foi plaqueado em forma de estrias sobre meio de cultura nutriente-ágar (NA). As placas foram mantidas a $27^{\circ} \mathrm{C}$ em condição de escuro, sendo após 3 dias efetuado o isolamento des colônias bacterianas com coloração amarelada e formato arredondado, típico da bactéria. Estas colônias foram repicadas para novo meio NA e utilizadas com no máximo 3 dias de crescimento. 
Tobacco mosaic virus - TMV: o vírus foi multiplicado em plantas sadias de fumo (Nicotiana tabacum) cv. Turkish, onde a colonização é sistêmica, através da inoculação mecânica das folhas. Para a purificação parcial do vírus, foram utilizadas folhas novas exibindo sintomas de mosaico, coletadas 20 dias após a inoculação das plantas. Amostras de tecido foliar infectado (60 g) foram coletadas e congeladas, sendo homogeneizadas em $120 \mathrm{~mL}$ em solução EDTA 3 mM (pH 7,0) mais $190 \mu \mathrm{L} \beta$ mercaptoetanol, utilizando liquidificador. O extrato obtido foi filtrado em gaze, aquecido a $55^{\circ} \mathrm{C}$ por $10 \mathrm{~min}$ e centrifugado a $1.500 \mathrm{~g}$ por $20 \mathrm{~min}$. O sobrenadante foi recolhido e centrifugado a 29.500 rpm (rotor Beckman “Type 30”) por 2 h, sendo o precipitado ressuspenso em EDTA 3 mM, pH 7,0 (1 mL / precipitado) e mantidos sobre agitação durante $12 \mathrm{~h}$ a $4{ }^{\circ} \mathrm{C}$. A suspensão obtida foi acidificada até $\mathrm{pH}$ 5,2 com ácido cítrico 0,05 M e centrifugada a 10.000 rpm por 25 min em rotor SS-34 (Beckman). O sobrenadante foi recolhido, sendo o $\mathrm{pH}$ ajustado para 7,0 com $\mathrm{NaOH}$ 0,05 M e também centrifugado a 29.500 rpm por 2 h (rotor “Type 30”). O precipitado obtido foi ressuspenso em $1 \mathrm{~mL}$ de EDTA 3 mM (pH 7,0) e a concentração desse purificado viral foi calculada com base na fórmula: c = Abs $(260 \mathrm{~nm}) /$ e, onde c é a concentração do vírus em mg/mL e e, o coeficiente de extinção do TMV, que equivale a 3,1 de absorbância para cada mg/mL de vírus. Finalmente, o isolado do vírus parcialmente purificado foi distribuído em tubos tipo eppendorf (alíquotas de $100 \mu \mathrm{L}$ cada) e mantidos em “Ultra deep freezer” a -70 C.

\subsection{Efeito de $L$. edodes sobre $C$. sublineolum}

\subsubsection{Efeito dos extratos aquosos de basidiocarpos de $L$. edodes na germinação de conídios e na formação de apressórios por $C$. sublineolum}

Em uma placa contendo a colônia de C. sublineolum foram colocados $10 \mathrm{~mL}$ de água destilada, sendo esta raspada com o auxílio de uma alça para a remoção dos conídios. Em seguida, alíquotas da suspensão de conídios foram transferidas para placa de ELISA. Cada pocinho (oito por tratamento) recebeu $40 \mu \mathrm{L}$ de suspensão de conídios 
( $10^{5}$ conídios $/ \mathrm{mL}$ de $C$. sublineolum) e $40 \mu \mathrm{L}$ de extrato aquoso bruto de basidiocarpos de um isolado de L. edodes. Foram testados os isolados LE JAB-K, LE 96/22, LE 96/17 e LE 95/01. A concentração final dos extratos foi de $50 \%$ (v/v) e a concentração final de C. sublineolum foi de $5 \times 10^{4}$ esporos $/ \mathrm{mL}$. A placa foi mantida no escuro a $23{ }^{\circ} \mathrm{C}$, durante 20 h. Após este período, efetuou-se a contagem do número de conídios germinados e apressórios formados através do emprego de azul de algodão com lactofenol e observação em microscópio ótico. O bioensaio foi conduzido três vezes sendo escolhido um dos experimentos para ilustrar os resultados obtidos.

\subsubsection{Efeito de extratos aquosos de basidiocarpos L. edodes sobre o crescimento micelial de $C$. sublineolum em meio de cultivo}

Alíquotas de 0,5 $\mathrm{mL}$ dos extratos aquosos de basidiocarpos $L$. edodes (isolados LE 96/22, LE 96/17 e LE 95/01) filtrados em sistema Millipore (filtro de 0,2 $\mu \mathrm{m}$ ) foram colocadas e espalhadas com uma alça de Drigalski sobre a superfície do meio de cultivo BDA em placas de Petri. As placas foram armazenadas por 24 h, sendo que após esse período, as mesmas receberam um disco de 0,6 cm de diâmetro contendo crescimento micelial de C. sublineolum. A seguir, as placas (seis para cada tratamento) foram mantidas sob condições de luz, a $26{ }^{\circ} \mathrm{C}$ e o crescimento diametral (cm) das colônias foi registrado a cada três dias até o momento em que as colônias das placas-controle atingiram todo o diâmetro das mesmas. O bioensaio foi repetido três vezes sendo escolhido um dos experimentos para ilustrar os resultados obtidos.

\subsubsection{Efeito de substâncias voláteis de $L$. edodes no crescimento micelial de $C$. sublineolum}

Placas de poliestireno divididas em duas partes contendo meio de cultivo BDA receberam em um dos compartimentos um disco de micélio com $0,3 \mathrm{~cm}$ de diâmetro de L. edodes. Após 7 dias, um disco de micélio ( $0,3 \mathrm{~cm}$ de diâmetro) de C. sublineolum foi 
colocado no outro compartimento da mesma placa. As placas-controle, contendo meio de cultivo BDA, receberam em um dos compartimentos apenas o disco de micélio do fungo patogênico. O crescimento diametral das colônias foi avaliado a cada dois dias até o momento em que as colônias das placas controle atingiram todo o diâmetro das mesmas. Cada tratamento consistiu em seis repetições.

\subsection{Efeito de L. edodes sobre A. solani}

\subsubsection{Efeito dos extratos aquosos de basidiocarpos de L. edodes na germinação de conídios de $A$. solani}

Em uma placa contendo a colônia de A. solani foram colocados $10 \mathrm{~mL}$ de água destilada, sendo esta raspada com o auxílio de uma alça para a remoção dos conídios. Em seguida, alíquotas da suspensão de conídios foram transferidas para a placa de ELISA. Cada pocinho (oito por tratamento) recebeu $40 \mu \mathrm{l}$ de suspensão de conídios ( $8 \times 10^{4}$ conídios/mL de $A$ solani) e $40 \mu \mathrm{l}$ de extrato aquoso de $L$. edodes. Foram testados os isolados LE JAB-K, LE 96/22, LE 96/17 e LE 95/01. A concentração final dos extratos de basidiocarpos foi de $50 \%$ (v/v) e a concentração final de A. solani foi de 4 x $10^{4}$ esporos/mL. A placa foi mantida no escuro a $26{ }^{\circ} \mathrm{C}$, durante 2,5 h. Após este período, efetuou-se a contagem do número de conídios germinados através do emprego de azul de algodão com lactofenol e observação em microscópio ótico.

\subsubsection{Efeito de extratos aquosos de $L$. edodes sobre o crescimento micelial de $A$. solani em meio de cultivo}

Em placas contendo meio de cultivo BDA, 0,5 $\mathrm{mL}$ dos extratos aquosos de basidiocarpos de L. edodes (isolados LE JAB-K, LE 96/22, LE 96/17 e LE 95/01) filtrados em sistema Millipore (filtro de 0,2 $\mu \mathrm{m}$ ) foram colocados e espalhados com alça 
de Drigalski sobre a superfície do meio. As placas foram armazenadas por 24 h e, após esse período, receberam um disco de $0,6 \mathrm{~cm}$ de diâmetro contendo crescimento micelial de A. solani. As placas (seis para cada tratamento) foram mantidas sob condições de luz fluorescente, a $25{ }^{\circ} \mathrm{C}$ e o crescimento diametral $(\mathrm{em} \mathrm{cm})$ das colônias foi avaliado a cada três dias até o momento em que as colônias do tratamento controle (água no lugar dos extratos) atingiram a borda das placas.

\subsection{Efeito de L. edodes sobre Xanthomonas axonopodis pv. passiflorae}

\subsubsection{Efeito dos extratos aquosos de basidiocarpos e dos filtrados do crescimento micelial de $L$. edodes na multiplicação de $X$. axonopodis pv. passiflorae}

Em tubos de ensaio, os extratos aquosos de basidiocarpos dos diferentes isolados (LE 96/17, LE JAB-K, LE 95/01 e LE 96/22) foram misturados com água destilada de modo a serem obtidos tubos com concentração final de 5, 10, 15 e 20\% (v/v), além do tratamento controle (água). Em seguida, os tubos de ensaio contendo os tratamentos receberam $1 \mathrm{~mL}$ da suspensão bacteriana a 80\% de transmitância (680 nm) sendo agitados e incubados no escuro durante 24 horas a $30{ }^{\circ} \mathrm{C}$. Após a incubação, foram tomadas cinco alíquotas de $250 \mu \mathrm{L}$ de cada um dos tubos, as quais foram plaqueadas sobre o meio de cultivo nutriente-ágar e espalhadas imediatamente, com auxílio de uma alça de Drigalski. As placas (cinco por tratamento) assim preparadas foram incubadas em condições de escuro a $30^{\circ} \mathrm{C}$. Decorridos 3 dias, a avaliação dos resultados foi efetuada pela suspensão do crescimento bacteriano de cada placa em $20 \mathrm{~mL}$ de água destilada e leitura da transmitância em espectrofotômetro a $680 \mathrm{~nm}$. Os valores de transmitância foram transformados em valores de absorbância a fim de facilitar a representação gráfica do crescimento bacteriano.

Outro experimento nos moldes do anterior foi realizado com extratos aquosos de basidiocarpos dos isolados de $L$. edodes cultivados em toras de eucaliptos, extratos aquosos de basidiocarpos dos isolados obtidos em cultivo axênico e filtrados do 
crescimento micélial de L. edodes, na concentração final de $20 \%$ (v/v), juntamente com suspensão bacteriana descrita anteriormente.

\subsubsection{Efeito da autoclavagem de extratos aquosos de L. edodes na multiplicação de $X$. axonopodis pv. passiflorae}

Os extratos aquosos de basidiocarpos dos isolados LE JAB-K, LE 95/01 e LE 96/22 (20\% v/v) foram autoclavados durante 20 min. a $121^{\circ} \mathrm{C}$ e $1 \mathrm{~atm}$ de pressão. Após o esfriamento dos extratos, os tubos de ensaio contendo os tratamentos receberam $1 \mathrm{~mL}$ da suspensão bacteriana a $80 \%$ de transmitância $(680 \mathrm{~nm})$ e em seguida foram agitados e incubados no escuro durante $24 \mathrm{~h}$ a $30^{\circ} \mathrm{C}$. Como controle, utilizaram-se tubos de ensaio contendo extratos aquosos não autoclavados mais suspensão bacteriana. Após a incubação, foram tomadas alíquotas de $250 \mu \mathrm{l}$ de cada um dos tubos, as quais foram plaqueadas sobre meio de cultivo nutriente-ágar e espalhadas imediatamente, com auxílio de uma alça de Drigalski. As placas assim preparadas foram incubadas em condições de escuro a $30^{\circ} \mathrm{C}$. Decorrido 3 dias, a avaliação dos resultados foi efetuada pela suspensão do crescimento bacteriano de cada placa em $20 \mathrm{~mL}$ de água destilada e leitura da transmitância em espectrofotômetro a $680 \mathrm{~nm}$. Os valores de transmitância foram transformados em valores de absorbância a fim de facilitar a representação gráfica do crescimento bacteriano.

\subsection{Efeito de L. edodes sobre Tobacco mosaic virus (TMV)}

\subsubsection{Efeito de extratos aquosos de basidiocarpos de $L$. edodes na infectividade do TMV}

Sementes de fumo (Nicotiana tabacum) da cultivar Turkish NN foram plantadas em bandejas de isopor contendo substrato Plantmax. Quando as plantas atingiram 
aproximadamente $8,0 \mathrm{~cm}$ de altura foram transferidas para vasos contendo solo autoclavado, sendo mantida uma planta por vaso. A seguir, três folhas de fumo localizadas na parte médio-basal da planta, foram pulverizadas com extratos aquosos de basidiocarpos de L. edodes, utilizando $5 \mathrm{~mL}$ do material por folha. Os extratos aquosos de basidiocarpos dos isolados LE 96/22 e LE 96/17 foram utilizados na concentração final de 10, 20, 30, 40 e 50\% (v/v), incluindo o tratamento controle (água destilada). Após 24 horas da aplicação dos tratamentos nas folhas, as mesmas foram inoculadas mecanicamente de maneira homogênea com o TMV. O vírus parcialmente purificado foi diluído com tampão fosfato até atingir a concentração final de $0,01 \mathrm{mg} / \mathrm{mL}$. As plantas (quatro por tratamento) foram mantidas em condições de casa de vegetação e após 4 dias da inoculação das folhas, efetuou-se a contagem do número de lesões locais.

Em outro experimento, quatro plantas de fumo 'Turkish NN' foram pulverizadas com água destilada ou com extratos aquosos de basidiocarpos dos isolados LE 96/22 e LE JAB-K a $10 \%$ (v/v). Em cada tratamento, todas as folhas foram pulverizadas, exceto uma meia-folha de cada planta, na qual efetuou-se a inoculação mecânica com TMV na concentração de $0,01 \mathrm{mg} / \mathrm{mL}$. A avaliação das lesões foi realizada ao $4^{\circ}$ dia do ensaio, através da contagem do número de lesões locais em meia folha.

\subsubsection{Efeito da autoclavagem de extratos aquosos de $L$. edodes na infectividade do TMV}

Sementes de fumo (Nicotiana tabacum) do cultivar Turkish NN foram plantadas em bandejas de isopor contendo substrato Plantmax. Quando as plantas atingiram aproximadamente $8,0 \mathrm{~cm}$ de altura foram transferidas para vasos contendo solo autoclavado, sendo mantida uma planta por vaso. O vírus parcialmente purificado foi diluído com extratos aquosos de basidiocarpos do isolado LE 96/22 (40\% v/v) ou com água destilada atingindo a concentração de $0,01 \mathrm{mg} / \mathrm{mL}$. Entretanto, um dos extratos aquosos de $L$. edodes foi autoclavado por $15 \mathrm{~min}$ a $121^{\circ} \mathrm{C}$ e $1 \mathrm{~atm}$ de pressão sendo em seguida, realizado o esfriamento do mesmo antes da mistura com o vírus. Assim, três 
folhas da planta (seis plantas por tratamento) foram inoculadas mecanicamente com as preparações e mantidas em telado de madeira coberto com sombrite. Após 5 dias da inoculação das folhas foi realizada a contagem do número de lesões locais.

\subsection{Separação dos componentes do extrato aquoso de basidiocarpos do isolado LE 96/22 de L. edodes através de cromatografia de troca aniônica (CTA)}

Setenta e cinco $\mathrm{mL}$ de extrato aquoso de basidiocarpos do isolado LE 96/22 foram liofilizados e ressuspensos em $5 \mathrm{~mL}$ de água destilada. Em seguida, a amostra foi filtrada (filtro com poros de 0,2 $\mu \mathrm{m}$ diâmetro), degaseificada por 10 min e submetida à CTA em coluna (2,5 cm de diâmetro interno x 15,0 cm de comprimento) preenchida com DEAE-Celulose e eluídas com o tampão fosfato de sódio $25 \mathrm{mM}$ (pH 6,0) e fluxo de $2,5 \mathrm{~mL} / \mathrm{min}$. O tampão foi filtrado em sistema Millipore (filtro de 0,2 $\mu \mathrm{m}$ ) e degaseificado por 10 min. $\mathrm{O}$ material adsorvido à resina foi eluído por gradiente linear de $\mathrm{NaCl}(0$ a $1 \mathrm{M})$. As frações de $5 \mathrm{~mL}$ foram coletadas e agrupadas de acordo com os picos sendo que a concentração de proteínas durante a eluição foi monitorada através da Abs a $280 \mathrm{~nm}$. Em seguida, as amostras foram dialisadas contra água destilada, sendo utilizadas membranas com limite de exclusão equivalente a 12.000-14.000 Da. Após a diálise, as amostras foram concentradas com polietilenoglicol 20.000 até a obtenção de um volume final de $9 \mathrm{~mL}$ e utilizadas nos bioensaios in vitro com $C$. sublineolum, A. solani e $X$. axonopodis pv. passiflorae.

Para os bioensaios com o TMV, uma amostra de $60 \mathrm{~mL}$ do extrato aquoso de basidiocarpos liofilizado do isolado LE 96/22 foi ressuspenso em $4 \mathrm{~mL}$ de água destilada e em seguida, submetido à CTA em coluna (2,5 cm de diâmetro interno x 15,0 cm de comprimento) empacotada com DEAE-Celulose. A cromatografia foi efetuada com tampão fosfato de sódio $25 \mathrm{mM}(\mathrm{pH}$ 6,0) e fluxo de $2,5 \mathrm{~mL} / \mathrm{min}$. O material adsorvido à resina foi eluído por gradiente linear de $\mathrm{NaCl}(0$ a $1 \mathrm{M})$. As frações coletadas foram agrupadas de acordo com os picos (Abs $280 \mathrm{~nm}$ ) e posteriormente, dialisadas contra água destilada, sendo utilizadas membranas com limite de exclusão equivalente a 
12.000-14.000 Da. Após a diálise, as amostras foram concentradas com polietilenoglicol 20.000 até o volume final de $9 \mathrm{~mL}$. Outra CTA foi realizada utilizando o procedimento descrito anteriormente, no entando, o material adsorvido à resina foi eluído pelo método "step-wise". Foi utilizado em cada etapa $150 \mathrm{~mL}$ do tampão fosfato contendo $\mathrm{NaCl}$ em concentrações crescentes $(0,200,400,600,800$ e $1000 \mathrm{mM})$. As frações coletadas foram agrupadas de acordo com os picos (Abs $280 \mathrm{~nm}$ ) e posteriormente, dialisadas contra água destilada, utilizando-se membranas com limite de exclusão equivalente a 12.000-14.000 Da. Após a diálise, as amostras foram concentradas com polietilenoglicol 20.000 até o volume final de $9 \mathrm{~mL}$.

\subsubsection{Efeito dos picos (frações agrupadas) de L. edodes no crescimento micelial de C. sublineolum e de $A$. solani}

Alíquotas de 0,1 mL das amostras obtidas a partir da CTA foram filtradas em seringa (filtro de $0,2 \mu \mathrm{m}$ ), colocadas e espalhadas sobre o meio de cultivo BDA em placas de Petri com 5,0 cm de diâmetro. Após 24 h, as placas receberam um disco de 0,3 cm de diâmetro contendo crescimento micelial de C. sublineolum ou A. solani e foram mantidas a $26{ }^{\circ} \mathrm{C}$ sob luz fluorescente constante. O crescimento diametral $(\mathrm{cm})$ das colônias de $C$. sublineolum foi avaliado a cada três dias. No caso de A. solani, a avaliação foi realizada a cada dois dias até o momento em que as colônias das placas controle atingiram todo o diâmetro das mesmas. Cada tratamento consistiu de 5 repetições sendo o experimento conduzido duas vezes.

\subsubsection{Efeito dos picos (frações agrupadas) de L. edodes na germinação de conídios e formação de apressórios por $C$. sublineolum e na germinação de conídios A. solani}

O teste de germinação de esporos foi realizado utilizando placas de ELISA, onde cada pocinho (oito por tratamento) recebeu conídios de C. sublineolum $\left(10^{5}\right.$ 
conídios $/ \mathrm{mL}$ ) ou de $A$. solani ( $8 \times 10^{4}$ conídios $/ \mathrm{mL}$ ) e $40 \mu$ dos tratamentos (picos). A placa com suspensão de conídios de C. sublineolum foi mantida no escuro a $23{ }^{\circ} \mathrm{C}$, durante $20 \mathrm{~h}$. Após este período, efetuou-se a contagem do número de conídios germinados e formação de apressórios através do emprego de azul de algodão com lactofenol e observação em microscópio ótico. Já a placa contendo os conídios de A. solani foi mantida no escuro a $26{ }^{\circ} \mathrm{C}$ por $2,5 \mathrm{~h}$, sendo em seguida realizada a contagem de conídios germinados através do emprego de azul de algodão com lactofenol e observação em microscópio ótico.

\subsubsection{Efeito dos picos (frações agrupadas) de $L$. edodes na multiplicação de $X$. axonopodis pv. passiflorae}

Tubos de ensaio contendo $0,9 \mathrm{~mL}$ das frações (picos), obtidas a partir da cromatografia de troca aniônica, receberam $0,1 \mathrm{~mL}$ de uma suspensão de células de $X$. axonopodis pv. passiflorae a $80 \%$ de transmitância a $680 \mathrm{~nm}$. O tratamento controle foi representado por água. Os tubos foram agitados e mantidos no escuro durante 24 h a 30 ${ }^{\circ} \mathrm{C}$. Posteriormente, alíquotas de $200 \mu \mathrm{l}$ de cada um dos tubos foram plaqueadas sobre meio de cultivo nutriente-ágar e espalhadas imediatamente, com auxílio de uma alça de Drigalski. Desta forma, as placas foram mantidas em condições de escuro a $30{ }^{\circ} \mathrm{C}$. Decorrido 2 dias, a avaliação dos resultados foi efetuada pela suspensão do crescimento bacteriano de cada placa em $20 \mathrm{~mL}$ de água destilada e leitura da transmitância em espectrofotômetro a $680 \mathrm{~nm}$.

\subsubsection{Efeito dos picos (frações agrupadas) de L. edodes sobre o TMV em plantas de fumo}

Para a realização dos bioensaios com plantas de fumo, 4,5 $\mathrm{mL}$ das frações agrupadas (picos) foram misturadas com 0,5 mL da suspensão de TMV $(0,01 \mathrm{mg} / \mathrm{mL})$. 
Em seguida, três folhas de fumo (cultivar Turkish NN) foram e inoculadas mecanicamente com as preparações, incluindo o tratamento controle (água mais TMV). Cada tratamento contou com cinco repetições, sendo uma repetição representada por um vaso com uma planta. Os vasos foram mantidos em telado de madeira coberto com sombrite. A contagem do número de lesões locais foi realizada 3 dias após a inoculação das folhas. Em outro experimento com plantas de fumo, 4,5 mL das frações de L. edodes obtidas em CTA pelo modo "step wise" foram misturadas com a suspensão de TMV $(0,01 \mathrm{mg} / \mathrm{mL})$. Três folhas da planta foram inoculadas mecanicamente. O mesmo procedimento descrito anteriormente foi realizado no ensaio, porém cada tratamento contou com seis repetições e a avaliação do número de lesões foi realizada 3 dias após a inoculação das folhas.

\subsubsection{Determinação da concentração de proteínas e carboidratos no extrato aquoso de basidiocarpos e nos picos (frações agrupadas) de $L$. edodes}

A dosagem de proteínas totais no extrato aquoso e picos do isolado LE 96/22 de $L$. edodes, obtidos por meio de cromatografia de troca aniônica, foi realizada segundo metodologia proposta por Bradford (1976), onde a cada 0,8 $\mathrm{mL}$ de amostra foram adicionados, 0,2 mL de reagente concentrado de Bradford. Após 5 min de incubação, à temperatura ambiente, foi realizada a leitura de absorbância a $595 \mathrm{~nm}$, tendo como referência a reação de $0,8 \mathrm{~mL}$ de água destilada com $0,2 \mathrm{~mL}$ do reagente. A curva padrão de proteínas (Apêndice 1. a) foi construída com albumina de soro bovino (ABS).

Para a dosagem de carboidratos totais do extrato aquoso e dos picos do isolado LE 96/22 de L. edodes, seguiu-se o método fenol sulfúrico (Dubois et al., 1956), onde a cada amostra de 0,5 mL foram adicionados, $0,5 \mathrm{~mL}$ de fenol (5\%) e rapidamente 2,5 $\mathrm{mL}$ de $\mathrm{H}_{2} \mathrm{SO}_{4}$. Após 30 min de incubação, à temperatura ambiente, foi realizada a leitura de absorbância a $490 \mathrm{~nm}$, tendo como referência a reação de $0,5 \mathrm{~mL}$ de água destilada com $0,5 \mathrm{~mL}$ de fenol (5\%) e 2,5 mL de $\mathrm{H}_{2} \mathrm{SO}_{4}$. A curva padrão de carboidratos foi detrminada usando glucose (Apêndice 1.b). 


\section{RESULTADOS}

\subsection{Efeito dos extratos aquosos de basidiocarpos de $L$. edodes na germinação de conídios, na formação de apressórios e no crescimento micelial de C. sublineolum}

Os extratos aquosos de basidiocarpos dos isolados LE JAB-K e LE 95/01 de L. edodes apresentaram significativa atividade inibitória sobre a germinação de esporos de C. sublineolum (Figura 6). Já os extratos aquosos de basidiocarpos dos isolados LE 96/17 e LE 96/22 apresentaram pouco ou nenhum efeito na redução da germinação dos esporos.

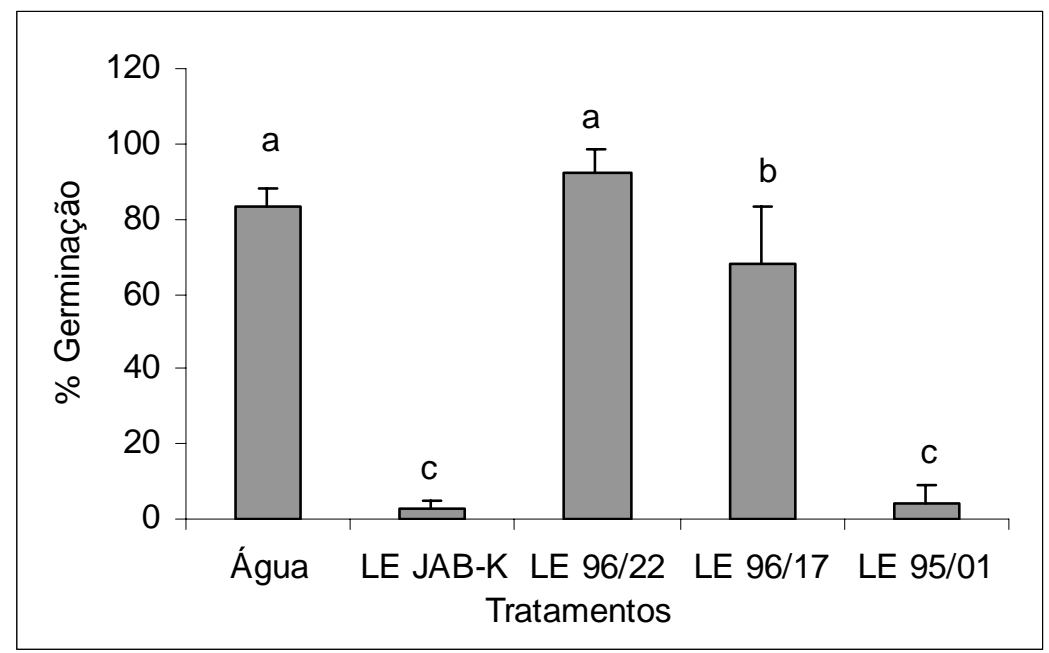

Figura 6 - Efeito de extratos aquosos de basidiocarpos dos isolados LE JAB-K, LE 96/22, LE 96/17 e LE 95/01 de Lentinula edodes na germinação de conídios de Colletotrichum sublineolum. As colunas representam a média, enquanto as barras, o desvio padrão dos valores. Médias seguidas pela mesma letra não diferem entre si pelo teste de Tukey a 5\% 
Com relação à formação de apressórios, os extratos aquosos de basidiocarpos de todos os isolados promoveram significativa redução no número de apressórios formados em relação ao controle (água) (Figura 7).

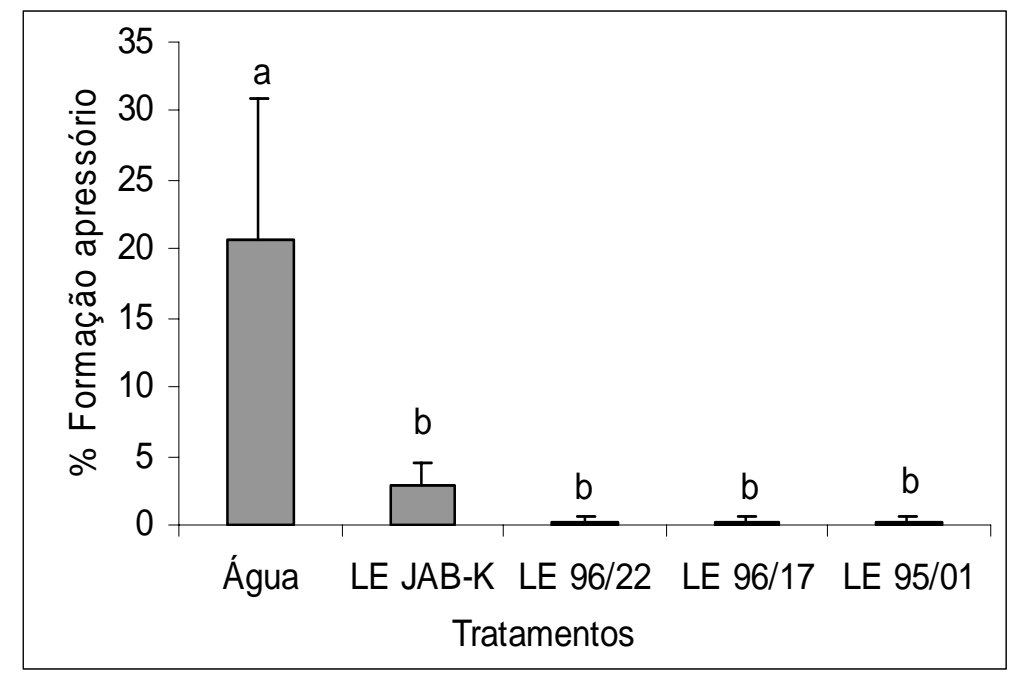

Figura 7 - Efeito de extratos aquosos de basidiocarpos dos isolados LE JAB-K, LE 96/22, LE 96/17 e LE 95/01 de Lentinula edodes na formação de apressórios por Colletotrichum sublineolum. As colunas representam a média, enquanto as barras, o desvio padrão. Médias seguidas pela mesma letra não diferem entre si pelo teste de Tukey a $5 \%$

O extrato aquoso de basidiocarpos do isolado LE 96/22 reduziu em torno de $80 \%$ o crescimento micelial de C. sublineolum, quando comparado ao tratamento controle ao $9^{\circ}$ dia da avaliação. Já os isolados LE 96/17 e LE 95/01 não apresentaram efeito inibitório sobre o crescimento micelial do patógeno (Figura 8). 


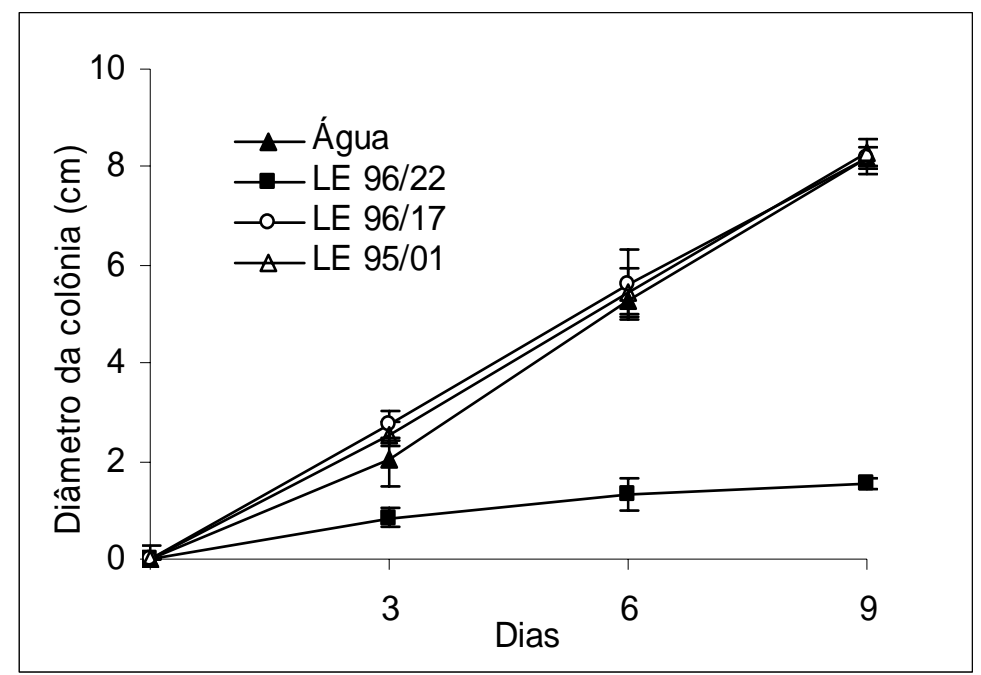

Figura 8 - Efeito de extratos aquosos de basidiocarpos dos isolados LE 96/22, LE 96/17 e LE 95/01 de Lentinula edodes no crescimento micelial de Colletotrichum sublineolum. As barras representam o desvio padrão da média

\subsection{Efeito de substâncias voláteis produzidas pelo micélio de L. edodes sobre o crescimento micelial de $C$. sublineolum}

Com base nos resultados representados na Figura 9, pode-se observar que houve redução parcial do crescimento micelial de C. sublineolum em função da presença de compostos voláteis do micélio de L. edodes. 


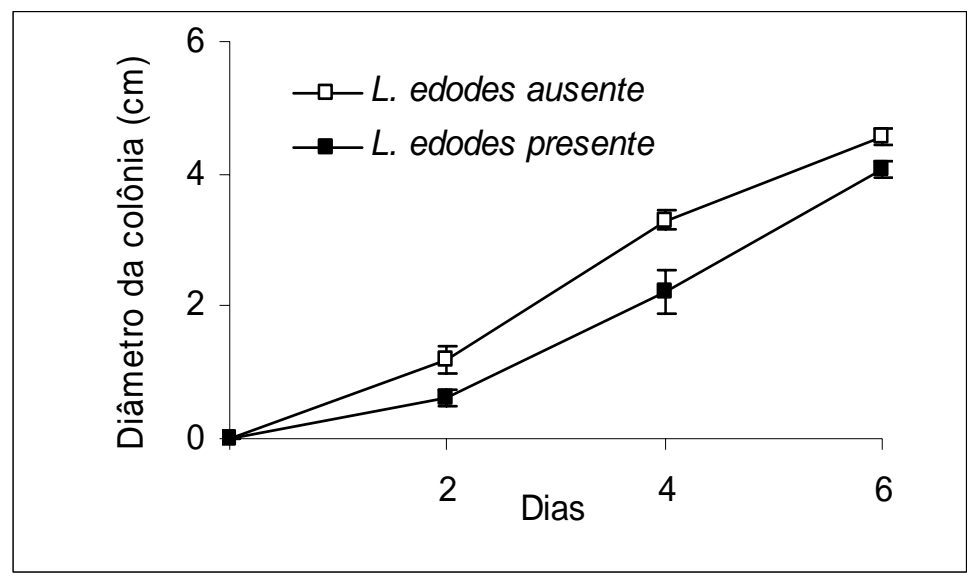

Figura 9 - Efeito de substâncias voláteis do micélio de Lentinula edodes (isolado LE 96/22) sobre o crescimento micelial de Colletotrichum sublineolum. Barras representam o desvio padrão da média

4.3 Efeito dos extratos aquosos de $L$. edodes na germinação de conídios e no crescimento micelial de $A$. solani

Observa-se que os extratos aquosos de basidiocarpos dos diferentes isolados não influenciaram no crescimento micelial e na germinação de conídios de A. solani em relação ao tratamento controle (Figuras 10 e 11). 


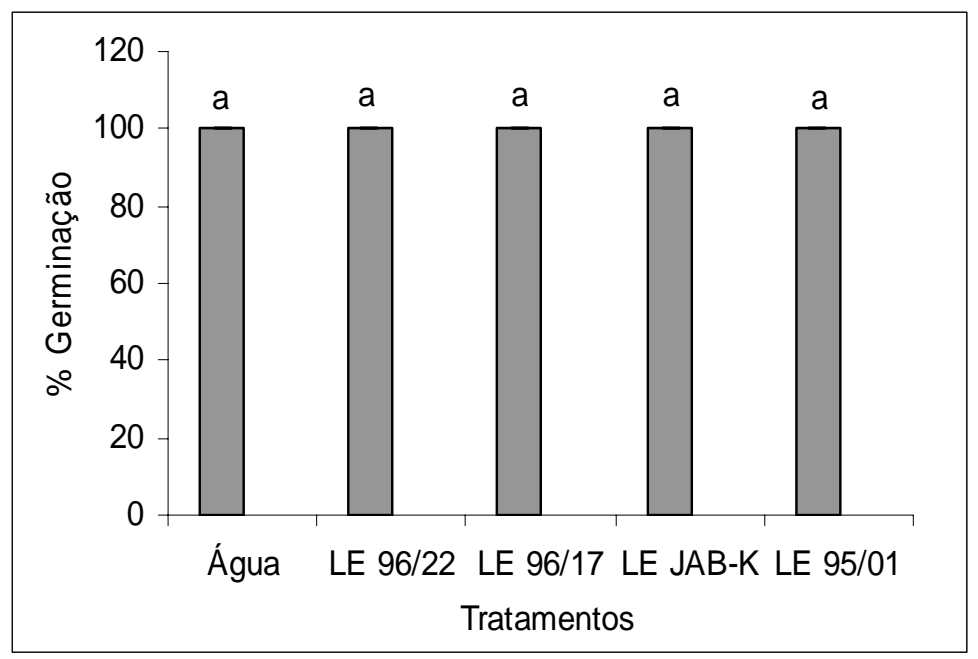

Figura 10 - Efeito de extratos aquosos de basidiocarpos dos isolados LE 96/22, LE 96/17, LE JAB-K e LE 95/01 de Lentinula edodes na germinação de conídios de Alternaria solani. As colunas representam a média. Médias seguidas pela mesma letra não diferem entre si pelo teste de Tukey a 5\%

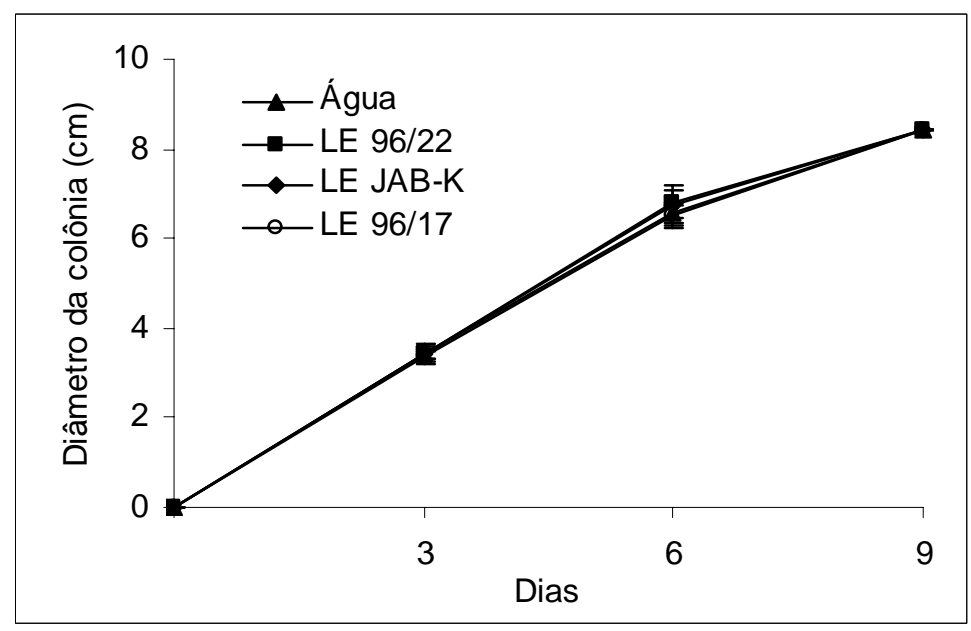

Figura 11 - Efeito de extratos aquosos de basidiocarpos dos isolados LE 96/22, LE JABK e LE 96/17 de Lentinula edodes no crescimento micelial de Alternaria solani. Barras representam o desvio padrão da média 


\subsection{Efeito de substâncias voláteis produzidas pelo micélio de L. edodes sobre o crescimento micelial de $A$. solani}

De acordo com os resultados obtidos na Figura 12, observa-se que não houve redução do crescimento micelial de A. solani na presença de compostos voláteis do micélio de L. edodes.

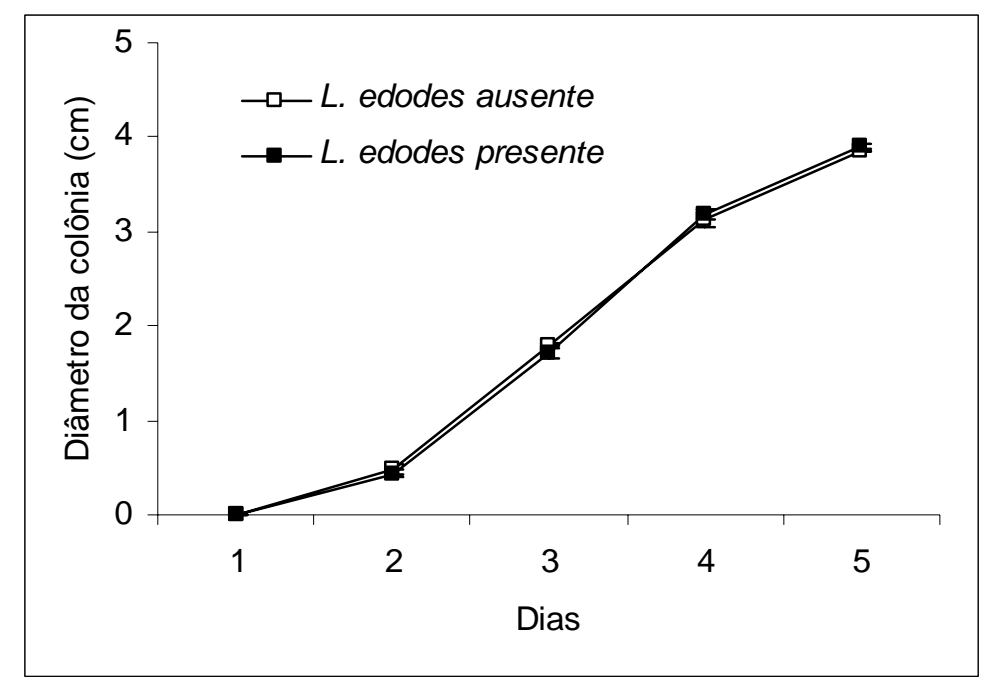

Figura 12 - Efeito de substâncias voláteis do micélio de Lentinula edodes (isolado LE 96/22) sobre o crescimento micelial de Alternaria solani. Barras representam o desvio padrão da média

4.5 Efeito dos extratos aquosos de diferentes isolados de L. edodes na multiplicação in vitro de $X$. axonopodis pv. passiforae

Com base na Figura 13, pode-se observar que todos os extratos de basidiocarpos proporcionaram redução significativa na multiplicação bacteriana. O efeito de L. edodes sobre $X$. axonopodis pv. passiflorae aumentou com a concentração dos extratos aquosos de basidiocarpos até 15\%. 


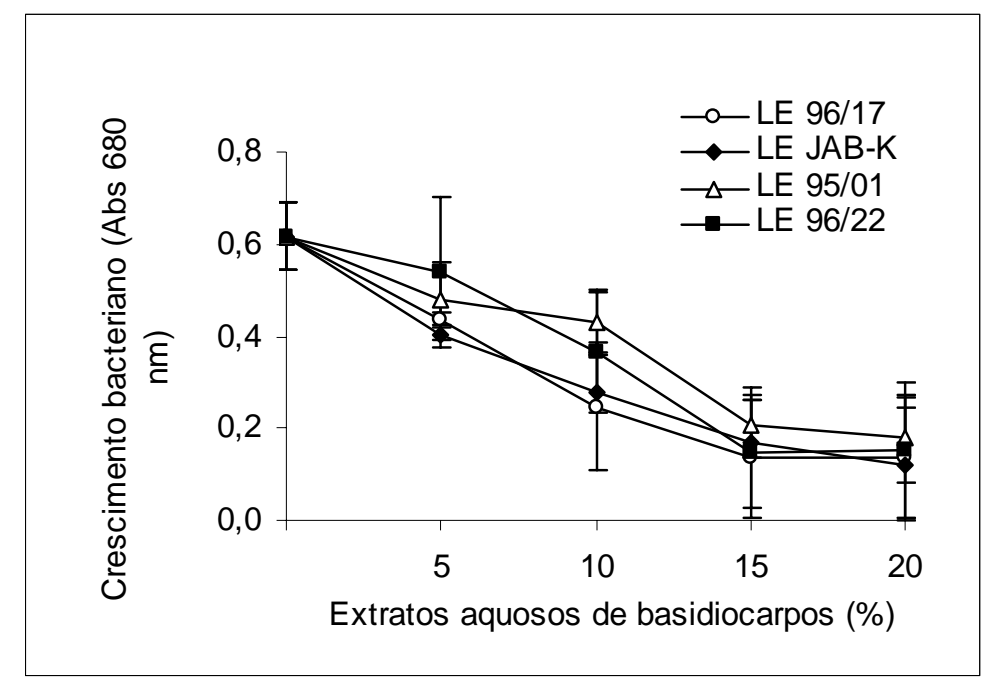

Figura 13 - Efeito de extratos aquosos de basidiocarpos de Lentinula edodes, em diferentes concentrações, na multiplicação in vitro de Xanthomonas axonopodis pv. passiflorae. As barras representam o desvio padrão. Valores representam a média de três experimentos distintos. Observou-se efeito significativo de doses dos extratos, através do teste $\mathrm{F}$ a $5 \%$

Por sua vez, os resultados ilustrados na Figura 14 demonstram que os extratos de basidiocarpos dos isolados LE 96/17 e LE 96/22 cultivados em toras de eucalipto e os filtrados de crescimento micelial dos isolados LE 99/61 e LE 99/57 reduziram a multiplicação bacteriana in vitro. Entretanto, os extratos de basidiocarpos dos isolados LE 96/17 e LE 96/22 obtidos em cultivo axênico, não diferiram do tratamento controle (água). 


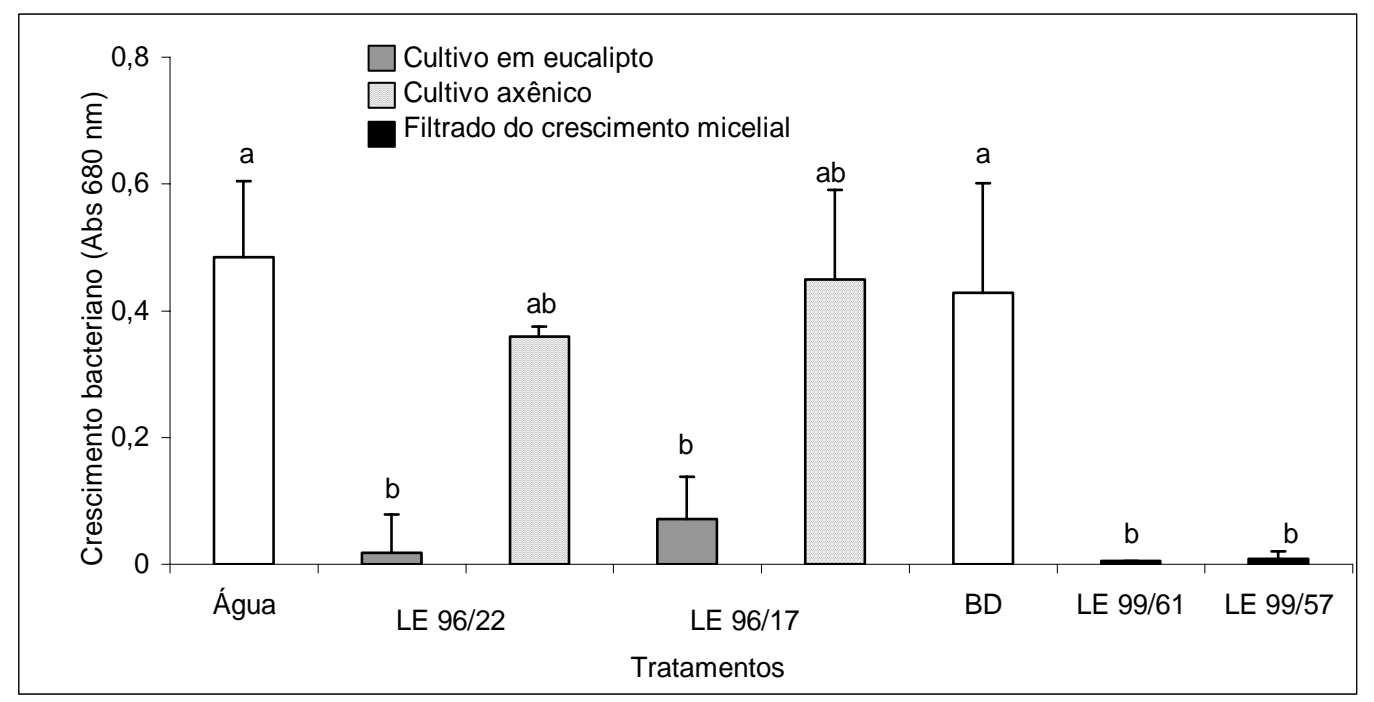

Figura 14 - Efeito de extratos aquosos de basidiocarpos dos isolados LE 96/22, LE 96/17 e do filtrado do crescimento micelial (FCM) dos isolados LE 99/61 e LE 99/57 de Lentinula edodes na multiplicação in vitro de Xanthomonas axonopodis pv. passiflorae. As preparações de L. edodes foram utilizadas na concentração de $20 \%(\mathrm{v} / \mathrm{v})$. As colunas representam a média, enquanto as barras, o desvio padrão. Médias seguidas pela mesma letra não diferem entre si pelo teste de Tukey a 5\%. $\mathrm{BD}=$ meio de cultivo batata-dextrose

Por sua vez, a autoclavagem dos extratos de basidiocarpo utlilizados a 20\% (v/v), resultou na perda de atividade biológica in vitro sobre o crescimento de $X$. axonopodis pv. passiflorae (Figura 15). 


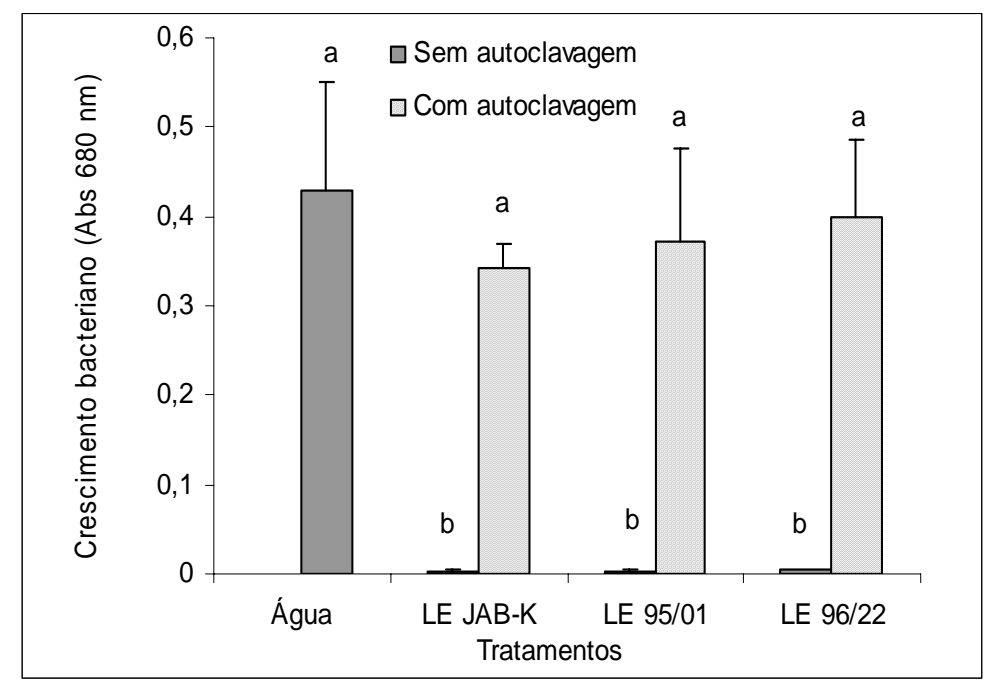

Figura 15 - Efeito da autoclavagem dos extratos aquosos de basidiocarpos dos isolados LE JAB-K, LE 95/01 e LE 96/22 de Lentinula edodes (concentração de 20\%) na multiplicação in vitro de Xanthomonas axonopodis pv. passiflorae. As colunas representam a média, enquanto as barras, o desvio padrão. Médias seguidas pela mesma letra não diferem entre si pelo teste de Tukey a 5\%

\subsection{Efeito dos extratos aquosos de basidiocarpos de $L$. edodes na infectividade do TMV}

Os extratos aquosos de basidiocarpos dos isolados LE 96/17 e LE 96/22 de $L$. edodes reduziram o número de lesões causadas por TMV em fumo (Figura 16). Um grande efeito inibitório ocorreu já na concentração de $10 \%$ dos extratos aquosos. Concentrações superiores não proporcionaram aumentos significativos na inibição do TMV. 


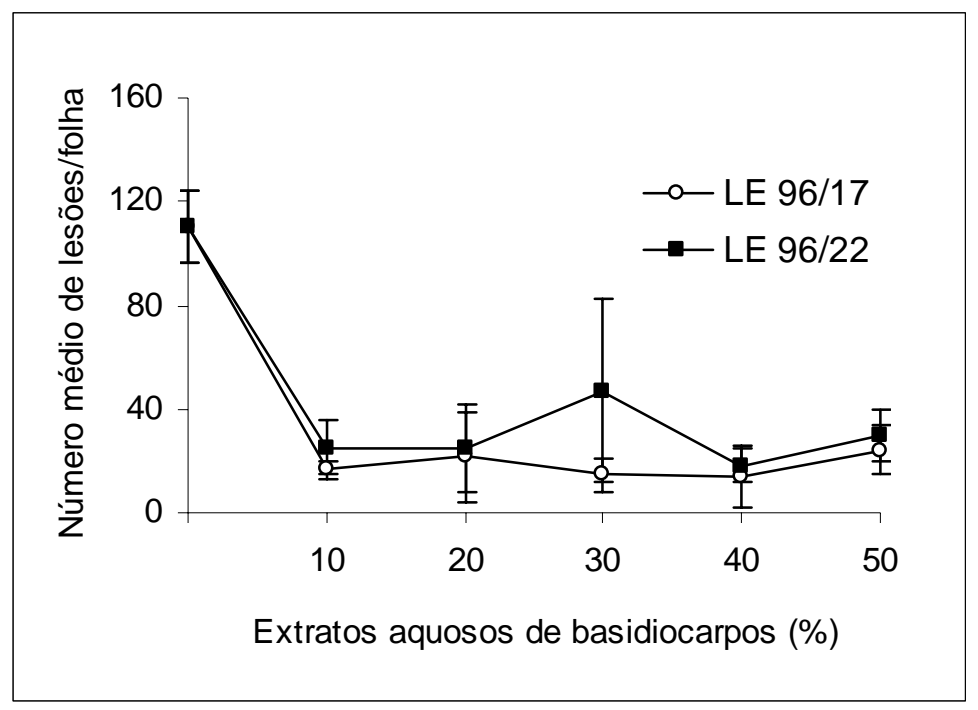

Figura 16 - Efeito de extratos aquosos de basidiocarpos de dois isolados de Lentinula edodes, em diferentes concentrações, na infectividade do Tobacco mosaic virus (TMV). As barras representam o desvio padrão. Efeito significativo de doses de extratos foi encontrado através do teste F, a $5 \%$

De acordo com a Figura 17, os extratos aquosos de basidiocarpos dos isolados LE 96/22 e LE JAB-K aplicados em meias-folhas de plantas de fumo reduziram significativamente a ocorrência de lesões locais na outra metade da folha quando comparada com folhas tratadas com água destilada (Figura 17). 


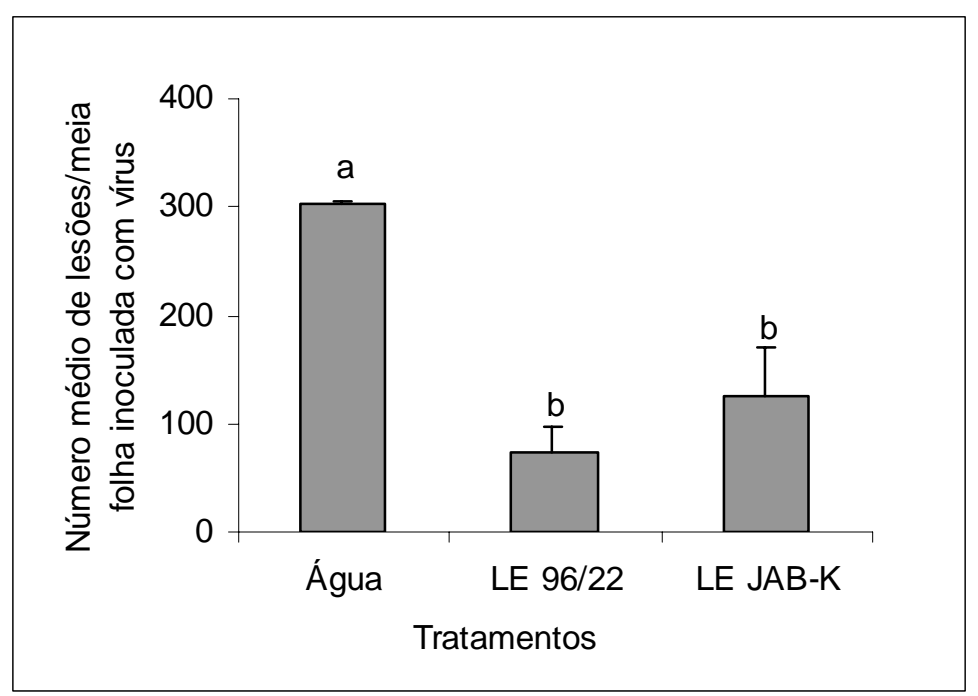

Figura 17 - Efeito de extratos aquoso de basidiocarpos de dois isolados de Lentinula edodes, na concentração de 10\%, na infectividade do Tobacco mosaic virus. Extrato aplicado em meia-folha, enquanto que o inóculo viral foi aplicado na outra metade da folha. As barras representam a média \pm desvio padrão. Médias seguidas pela mesma letra não diferem entre si pelo teste de Tukey a 5\%

A autoclavagem do extrato aquosos de basidiocarpos do isolado LE 96/22, utilizado a $40 \%$ (v/v), não interferiu sobre a atividade inibitória contra o TMV. O extrato do cogumelo reduziu em $67 \%$ as lesões locais das folhas de fumo quando comparado ao controle (água). Por sua vez, as folhas tratadas com o extrato aquoso não autoclavado apresentaram redução de $81 \%$ das lesões locais com relação ao tratamento com água (Figura 18). 


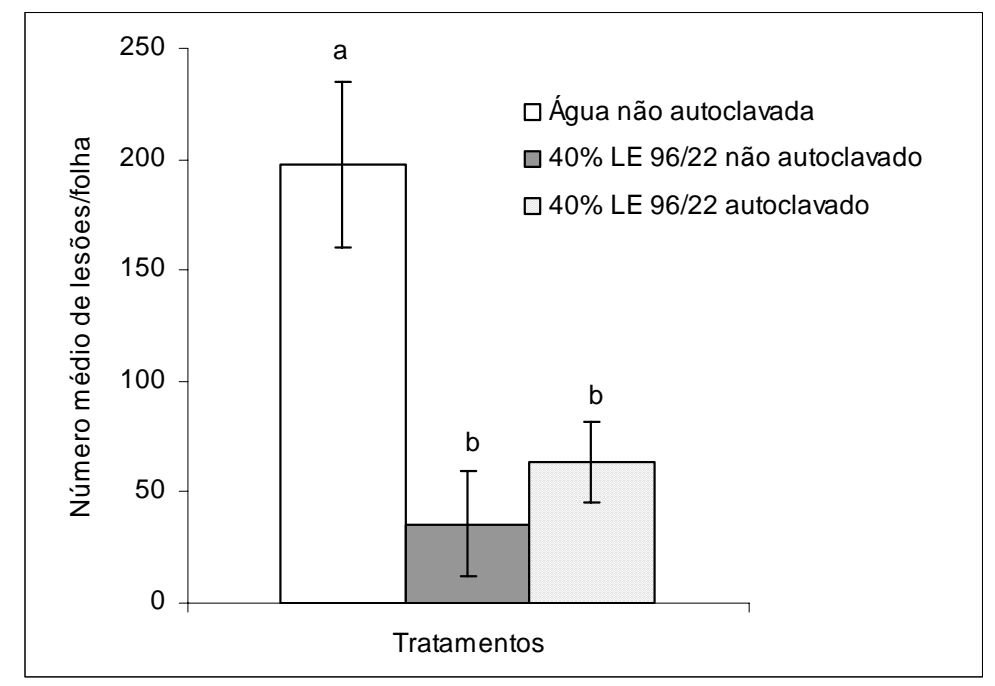

Figura 18 - Efeito da autoclavagem do extrato aquoso de basidiocarpos do isolado LE 96/22 de Lentinula edodes, a concentração de 40\%, na infectividade do Tobacco mosaic virus. O extrato autoclavado foi misturado com o inóculo viral no momento da inoculação. As colunas representam a média, enquanto as barras, o desvio padrão. Médias seguidas pela mesma letra não diferem entre si pelo teste de Tukey a 5\%

\subsection{Separação dos compostos de $L$. edodes por cromatografia de troca aniônica e o efeito in vitro sobre os fitopatógenos}

Dentre os isolados de L. edodes testados nos bioensaios, o isolado LE 96/22 propiciou maior efeito antimicrobiano sobre os fipatógenos estudados. Desta forma, o extrato aquoso deste isolado foi sumetido à CTA na tentativa de se concentrar o composto ativo. À vista disso, uma amostra contendo 42,6 mg de proteína e 1.583,1 mg de carboidratos totais do extrato aquoso de basidiocarpos liofilizado do isolado foi aplicada à coluna de CTA. Foram obtidos sete picos (frações agrupadas) (Figura 19) 
(Apêndice 2), os quais foram testados em bioensaios in vitro com C. sublineolum, $A$. solani e $X$. axonopodis pv. passiflorae.

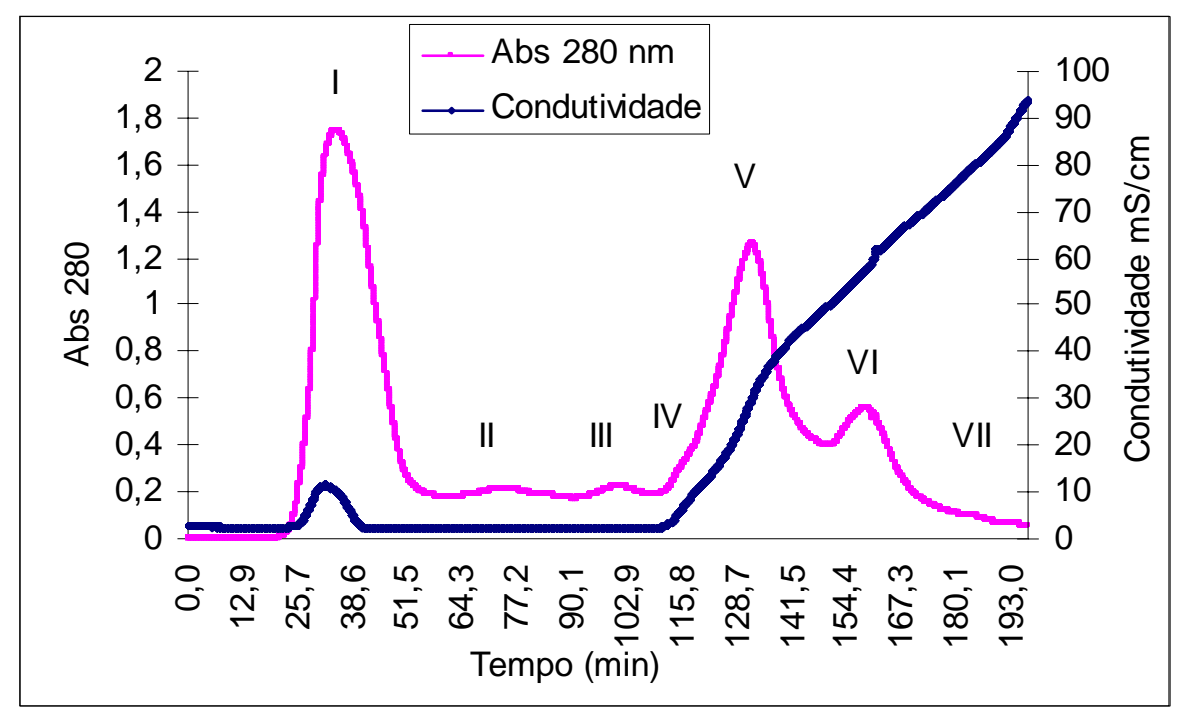

Figura 19 - Cromatografia de troca aniônica de extrato aquoso de basidiocarpos liofilizados de L. edodes, isolado LE 96/22. O material foi aplicado em coluna preenchida com DEAE-Celulose. A cromatografia foi efetuada com tampão fosfato 25 mM (pH 6,0) e o material adsorvido foi eluído por gradiente linear de $\mathrm{NaCl}$ no mesmo tampão (0 a $1 \mathrm{M})$

\subsubsection{Efeito na germinação de conídios, formação de apressórios e crescimento micelial de C. sublineolum}

Houve um efeito estimulador dos picos obtidos a partir do fracionamento do extrato aquoso de basidiocarpos de LE 96/22 por cromatografia de troca aniônica na germinação e formação de apressórios de C. sublineolum com relação ao tratamento controle (água) (Figuras 20 e 21). O crescimento micelial de C. sublineolum foi inibido pelas frações agrupadas no pico V, no entanto os picos I, II, III, IV, VI e VII não apresentaram efeito inibitório sobre o fungo (Figura 22). 


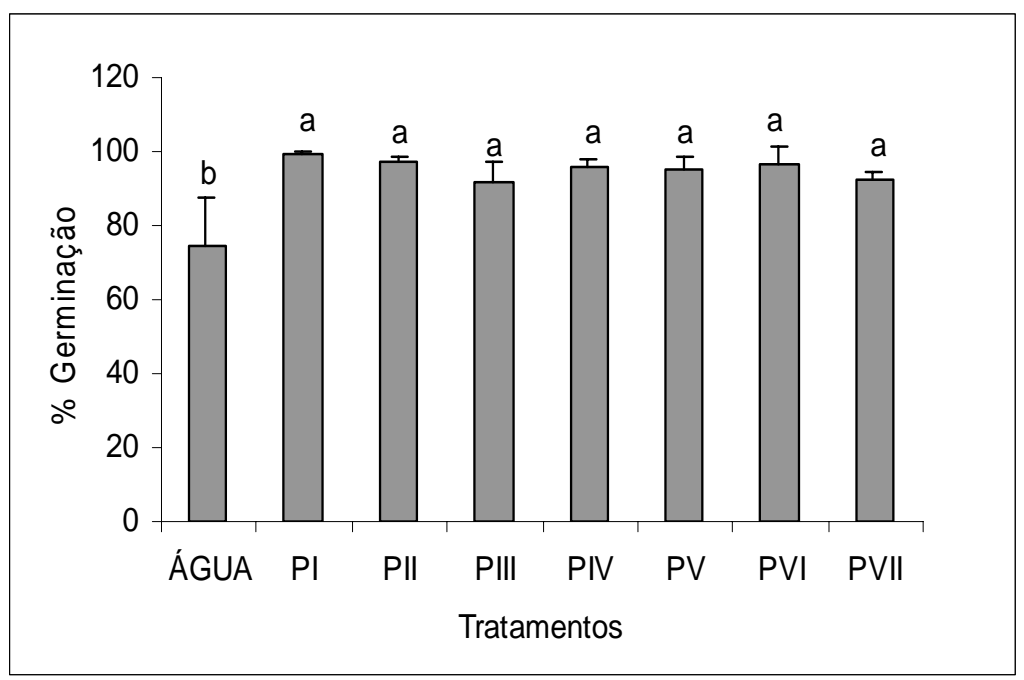

Figura 20 - Efeito dos constituintes dos diferentes picos de Lentinula edodes (LE 96/22), obtidas a partir da cromatografia de troca aniônica, sobre a germinação de conídios de Colletotrichum sublineolum. As colunas representam a média, enquanto as barras, o desvio padrão. Médias seguidas pela mesma letra não diferem entre si pelo teste de Tukey a 5\% 


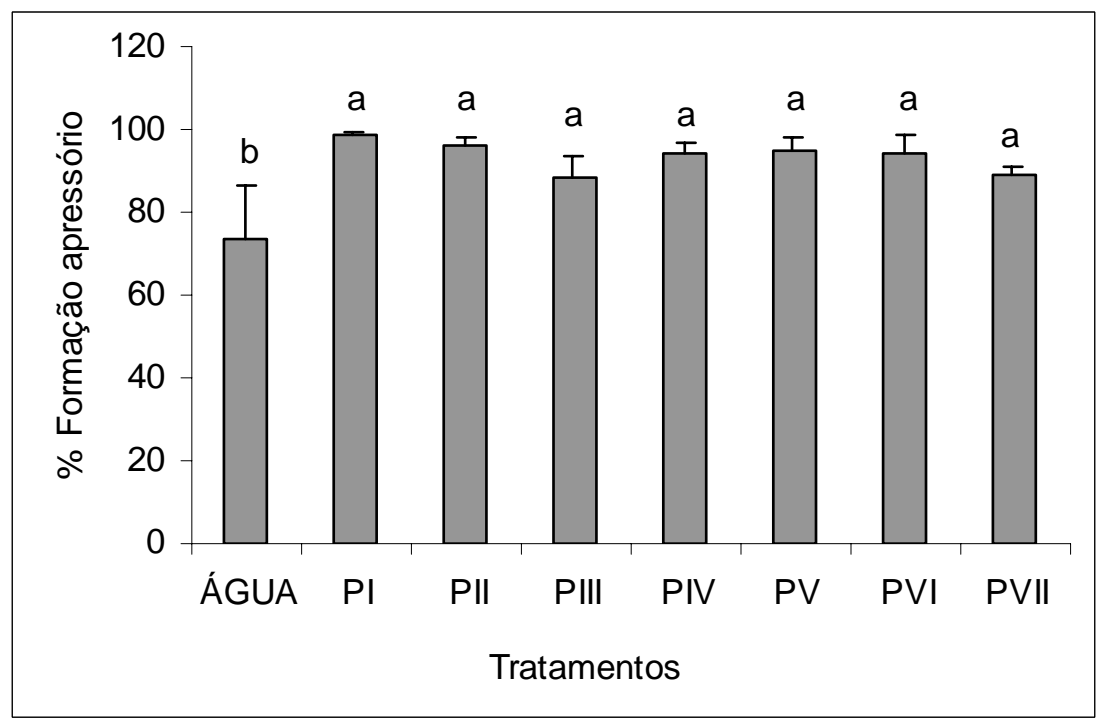

Figura 21 - Efeito de frações agrupadas de Lentinula edodes (LE 96/22), obtidas a partir da cromatografia de troca aniônica, na formação de apressórios por Colletotrichum sublineolum. As colunas representam a média, enquanto as barras, o desvio padrão. Médias seguidas pela mesma letra não diferem entre si pelo teste de Tukey a $5 \%$

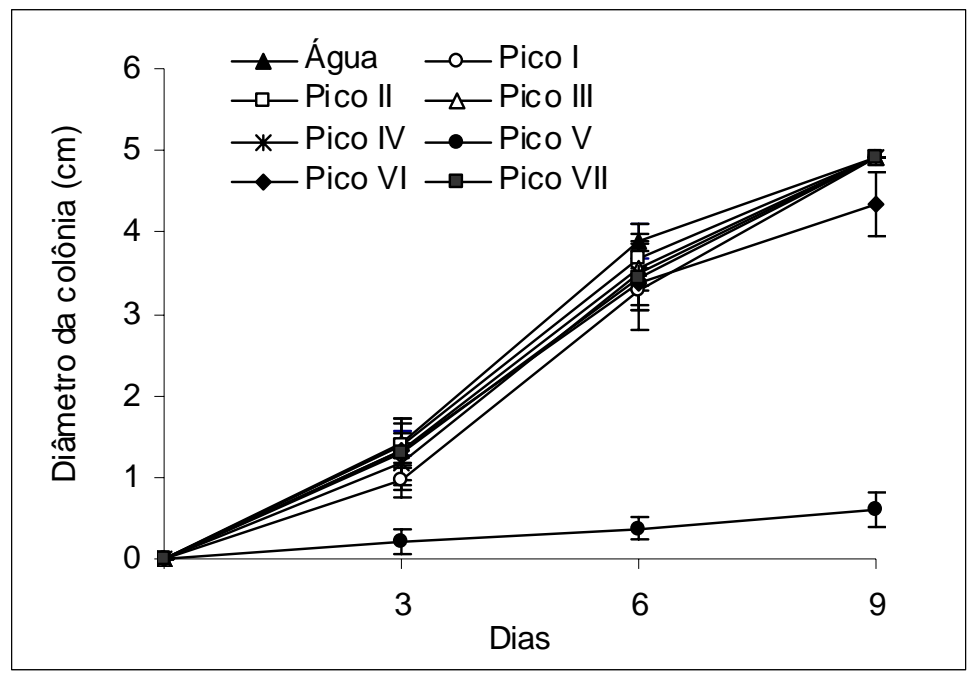

Figura 22 - Efeito das frações agrupadas (picos) de Lentinula edodes (LE 96/22), obtidas a partir da cromatografia de troca aniônica, no crescimento micelial de Colletotrichum sublineolum. Barras representam o desvio padrão da média 


\subsubsection{Efeito na germinação de conídios e no crescimento micelial de A. solani}

Os resultados obtidos com A. solani indicam a ausência da atividade inibitória dos picos (frações agrupadas) na germinação de conídios e no crescimento micelial do patógeno (Figuras 23 e 24).

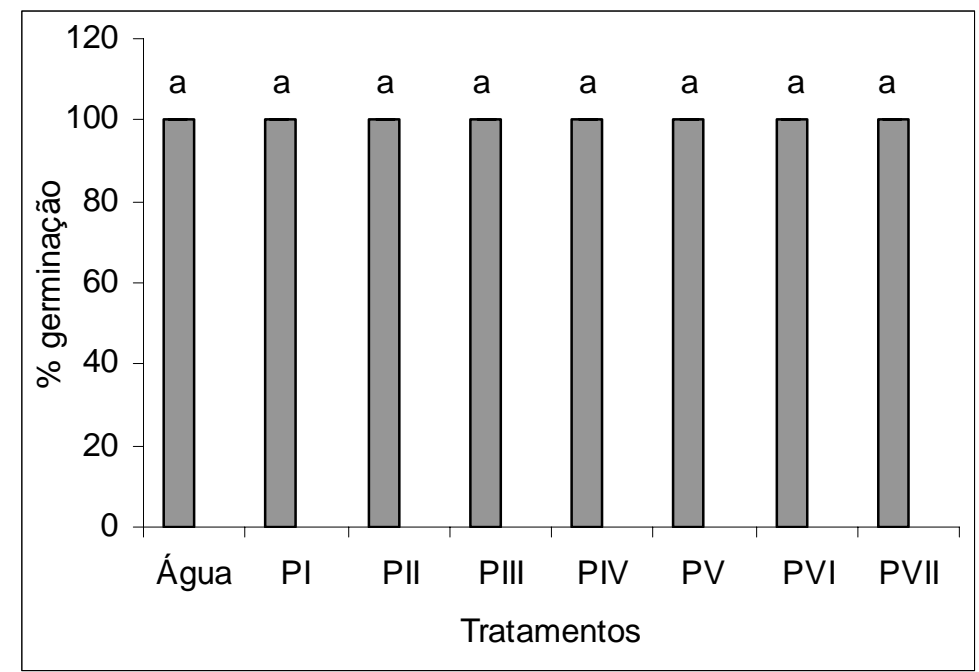

Figura 23 - Efeito dos constituintes dos diferentes picos de Lentinula edodes (isolado LE 96/22), obtidos a partir da cromatografia de troca aniônica, sobre a germinação de conídios de Alternaria solani. As colunas representam a média. Médias seguidas pela mesma letra não diferem entre si pelo teste de Tukey a $5 \%$ 


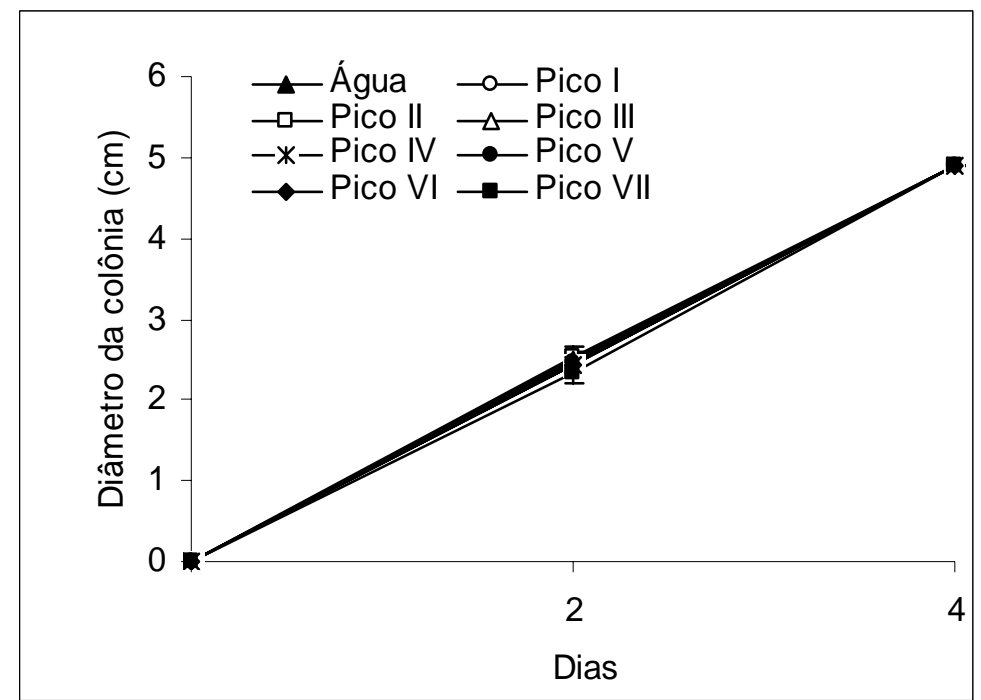

Figura 24 - Efeito das frações agrupadas de Lentinula edodes (LE 96/22), obtidas a partir da cromatografia de troca aniônica, no crescimento micelial de Alternaria solani. Barras representam o desvio padrão da média

\subsubsection{Efeito na multiplicação in vitro de $X$. axonopodis pv. passiflorae}

Como observado na Figura 25, as frações reunidas nos picos IV, V e VII propiciaram redução do crescimento bacteriano em relação ao controle (água). 


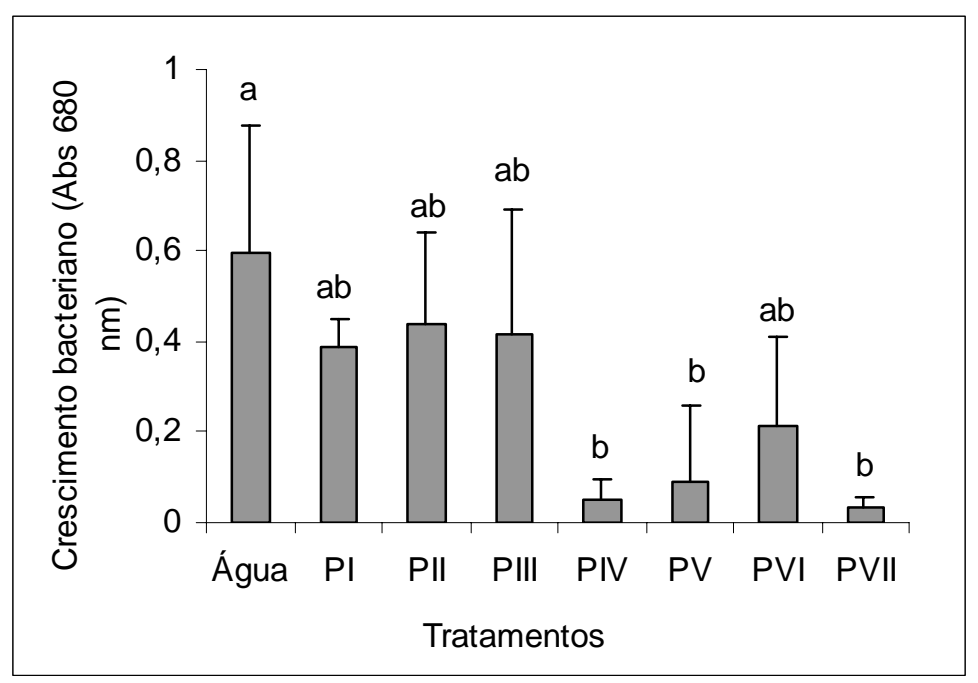

Figura 25 - Efeito das frações agrupadas de Lentinula edodes (isolado LE 96/22), obtidas a partir da cromatografia de troca aniônica, na multiplicação in vitro de Xanthomonas axonopodis pv. passiflorae. As colunas representam a média, enquanto as barras, o desvio padrão. Médias seguidas pela mesma letra não diferem entre si pelo teste de Tukey a 5\%

\subsection{Separação dos componentes do extrato de basidiocarpos de L. edodes, utilizando CTA, com atividade inibitória à infectividade de TMV}

O volume de amostras (frações agupadas) obtidas na primeira CTA não foi suficiente para a realização dos testes com TMV. Desta forma, uma amostra do extrato aquoso de basidiocarpos liofilizado do isolado LE 96/22 foi parcialmente purificada em CTA utilizando gradiente linear de $\mathrm{NaCl}$. Os picos obtidos, desta vez, mostraram-se um pouco mais separados principalmente com relação ao pico II, o qual se sobressaiu na CTA (Figura 26) (Apêndice 2), embora o padrão de separação fosse semelhante. Uma nova tentativa de separação do extrato aquoso de basidiocarpos liofilizado do mesmo isolado foi realizada em CTA adotando-se, desta vez, o procedimento “step wise” para a 
eluição de proteínas ligadas à resina DEAE-Celulose. Após a CTA, cinco picos foram obtidos (Figura 27) (Apêndice 2). Dessa maneira, para os bioensaios utilizando o patossistema fumo-TMV foram selecionados os picos ilustrados nas Figuras 26 e 27.

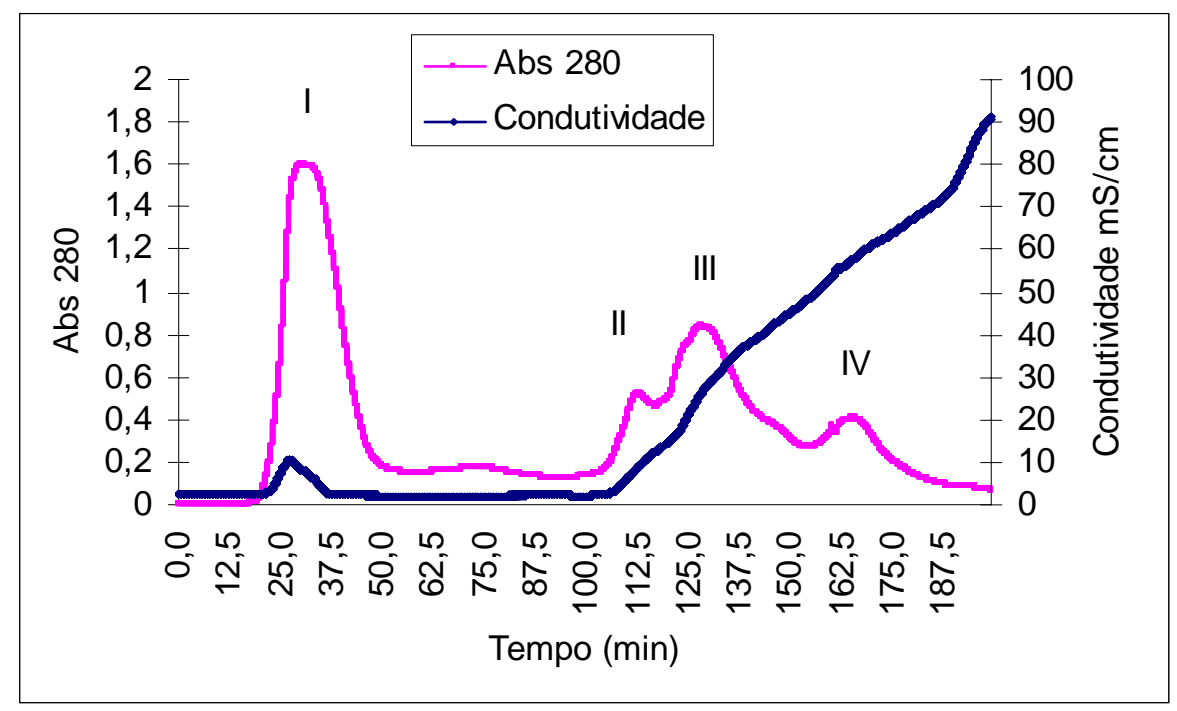

Figura 26 - Cromatografia de troca aniônica de extrato aquoso de basidiocarpos liofilizado de L. edodes, isolado 96/22. O material contendo 19,3 mg de proteína foi aplicado em coluna preenchida com DEAE-Celulose. A cromatografia foi efetuada com tampão fosfato $25 \mathrm{mM}(\mathrm{pH}$ 6,0) e o material adsorvido foi eluído por gradiente linear de $\mathrm{NaCl}(0$ a 1 M)

Com base nas Figuras 19, 26 e 27 aparentemente o pico I é o mesmo em todas as cromatografias, enquanto que o pico III das Figuras 26 e 27 corresponde ao pico V da Figura 19. Por sua vez, o pico IV das Figuras 26 e 27 corresponde ao pico VI da Figura 19. 


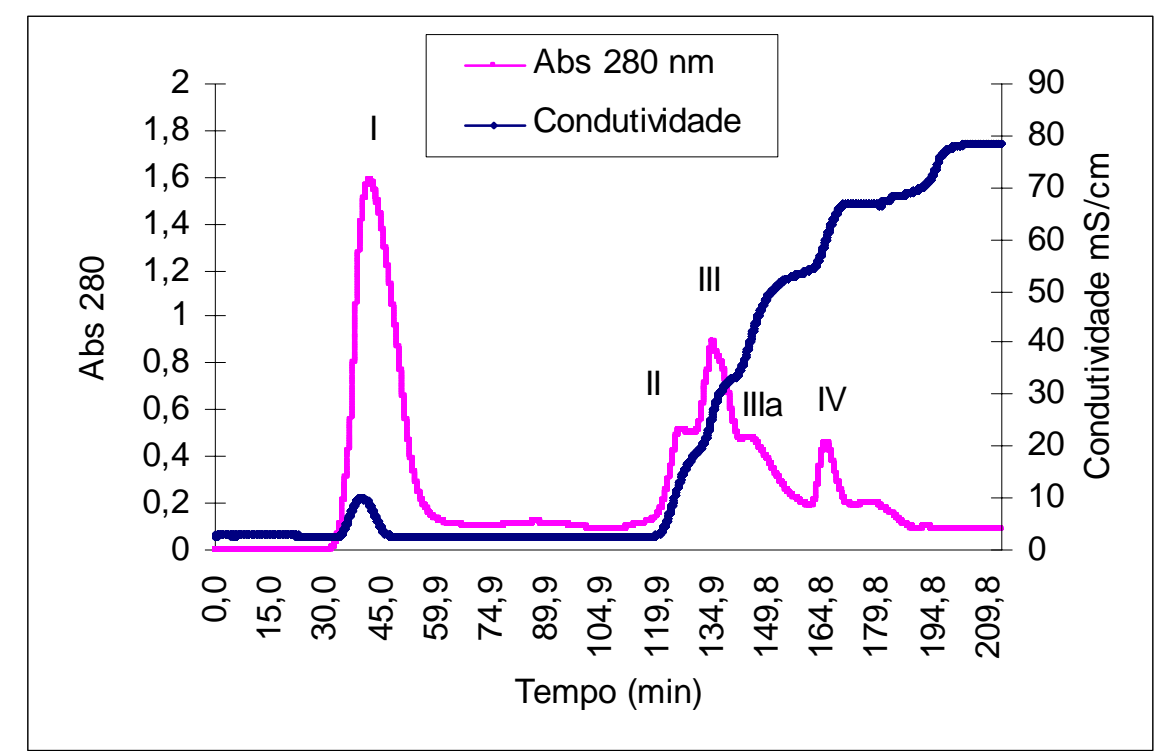

Figura 27 - Cromatografia de troca aniônica de extrato aquoso de basidiocarpos liofilizado de L. edodes, isolado 96/22. O material contendo 18,85 mg de proteína foi aplicado em coluna preenchida com DEAE-Celulose. A cromatografia foi efetuada com tampão fosfato $25 \mathrm{mM}(\mathrm{pH}$ 6,0) e o material adsorvido foi eluído com $\mathrm{NaCl}$ no mesmo tampão, em procedimento "step wise"

As dosagens de proteínas e carboidratos totais dos picos podem ser observadas na Tabela 1. Houve diferenças na concentração de proteínas contidas nos picos obtidos em CTA. Por sua vez, elevada concentração de carboidratos totais foi observada no pico I (frações não ligadas) representado nas Figuras 26 e 27. 
Tabela 1. Purificação parcial do extrato aquoso de basidiocarpos do isolado LE 96/22 de L. edodes, através de cromatografia de troca aniônica (CTA)

\begin{tabular}{|c|c|c|c|c|}
\hline \multirow[b]{2}{*}{ Etapas } & \multicolumn{3}{|c|}{ Recuperação } & \multirow{2}{*}{$\begin{array}{c}\text { Recuparação } \\
\text { Carboidratos } \\
\text { (\%) }\end{array}$} \\
\hline & Proteínas (mg) & Proteínas (\%) & $\begin{array}{c}\text { Carboidratos } \\
\text { Totais (mg) }\end{array}$ & \\
\hline i) Extrato bruto & 19,3 & 100 & $1.857,1$ & 100 \\
\hline Pico I & 0,4 & 2,0 & 115,2 & 6,2 \\
\hline Pico II & 0,2 & 1,1 & 4,5 & 0,2 \\
\hline Pico III & 0,4 & 2,1 & 2,7 & 0,1 \\
\hline Pico IV & 0,1 & 0,8 & 1,3 & 0,07 \\
\hline ii) Extrato bruto & 18,8 & 100 & $1.663,3$ & 100 \\
\hline Pico I & 0,3 & 1,5 & 103,6 & 6,2 \\
\hline Pico II & 0,4 & 2,1 & 4,7 & 0,2 \\
\hline Pico III & 0,3 & 1,6 & 1,8 & 0,1 \\
\hline Pico IIIa & 0,5 & 2,9 & 1,6 & 0,09 \\
\hline Pico IV & 0,3 & 1,9 & 1,8 & 0,1 \\
\hline
\end{tabular}

i) Extrato bruto liofilizado e separado em CTA utilizando gradiente linear de $\mathrm{NaCl}$ (Figura 26)

ii) Extrato bruto liofilizado e separado em CTA utilizando "step wise” (Figura 27)

\subsubsection{Efeito das frações de $L$. edodes sobre a infectividade do TMV}

A Tabela 2 apresenta a concentração de proteínas e carboidratos totais dos picos obtidos em CTA e o número médio de lesões locais de folhas inoculadas com o TMV.

Com base nos resultados, observa-se que os picos I, II e III, obtidos em CTA utilizando gradiente linear de $\mathrm{NaCl}$ apresentaram atividade antiviral significativa quando comparados ao tratamento com água. O pico IV não proporcionou efeito redutor sobre 
as lesões de TMV. Por sua vez, o pico I (frações não ligadas à resina) apresentou maior inibição sobre o TMV, reduzindo em $96 \%$ as lesões locais de folhas de fumo. Da mesma forma, como se pode observar na Tabela 2, o pico I (frações não ligadas à resina), obtido em CTA utilizando-se "step wise”, foi significativamente efetivo na atividade inibitória contra o TMV, reduzindo em 70\% as lesões locais das folhas inoculadas. Já os picos II, III, III a e IV não diferiram estatisticamente com relação ao controle (água).

Tabela 2. Efeito de frações agrupadas (picos), com base na Abs $280 \mathrm{~nm}$, de L. edodes sobre a infectividade de TMV em fumo

\begin{tabular}{ccc}
\hline Tratamentos & $\begin{array}{c}\text { mg proteínas em 4,5 } \\
\mathrm{mL}\end{array}$ & $\begin{array}{c}\text { mg de carboidratos } \\
\text { totais em } 4,5 \mathrm{~mL}\end{array}$ \\
\hline i) Água & - & - \\
Picos I & 0,2 & 57,6 \\
Pico II & 0,1 & 2,2 \\
Pico III & 0,2 & 1,3 \\
Pico IV & 0,08 & 0,6 \\
ii) Água & - & - \\
Pico I & 0,1 & 51,8 \\
Pico II & 0,2 & 2,3 \\
Pico III & 0,1 & 0,9 \\
Pico IIIa & 0,2 & 0,8 \\
Pico IV & 0,1 & 0,9 \\
\hline i) Picos obtidos em CTA utilizando gradiente linear de NaCl (Figura 26) \\
ii) Picos obtidos em CTA utilizando “step wise” (Figura 27)
\end{tabular}




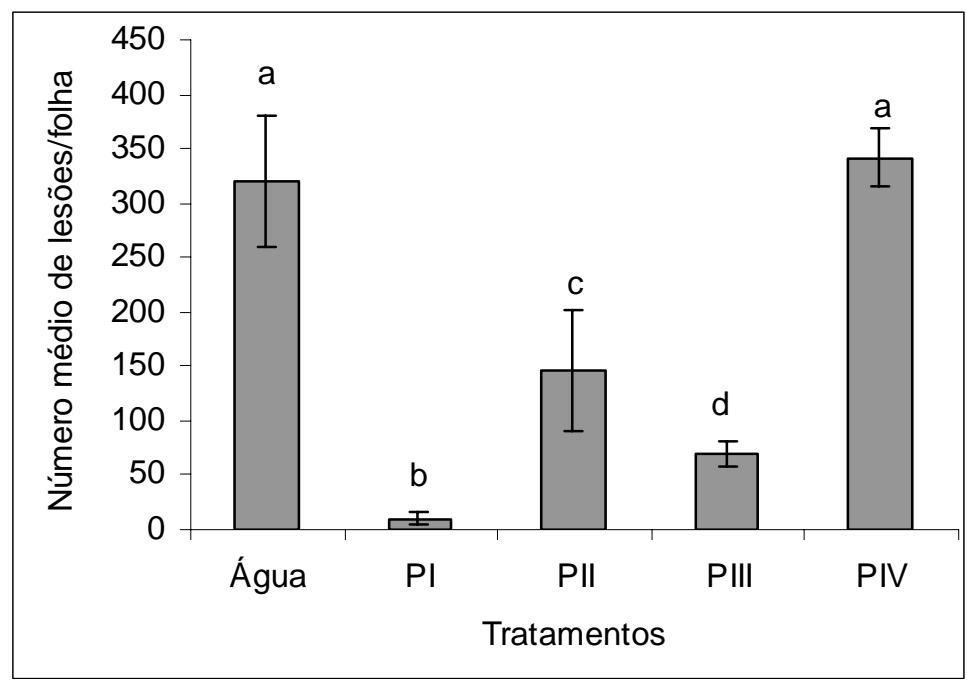

Figura 28 - Efeito local das frações agrupadas de Lentinula edodes (isolado LE 96/22) sobre a infectividade do Tobacco mosaic virus. As frações foram obtidas por cromatografia de troca aniônica utilizando gradiente linear de $\mathrm{NaCl}$ (0 a $1 \mathrm{M})$ e misturadas com o inóculo viral no momento da inoculação das folhas. As colunas representam a média, enquanto as barras, o desvio padrão. Médias seguidas pela mesma letra não diferem entre si pelo teste de Duncan a 5\%. CV=23\% 


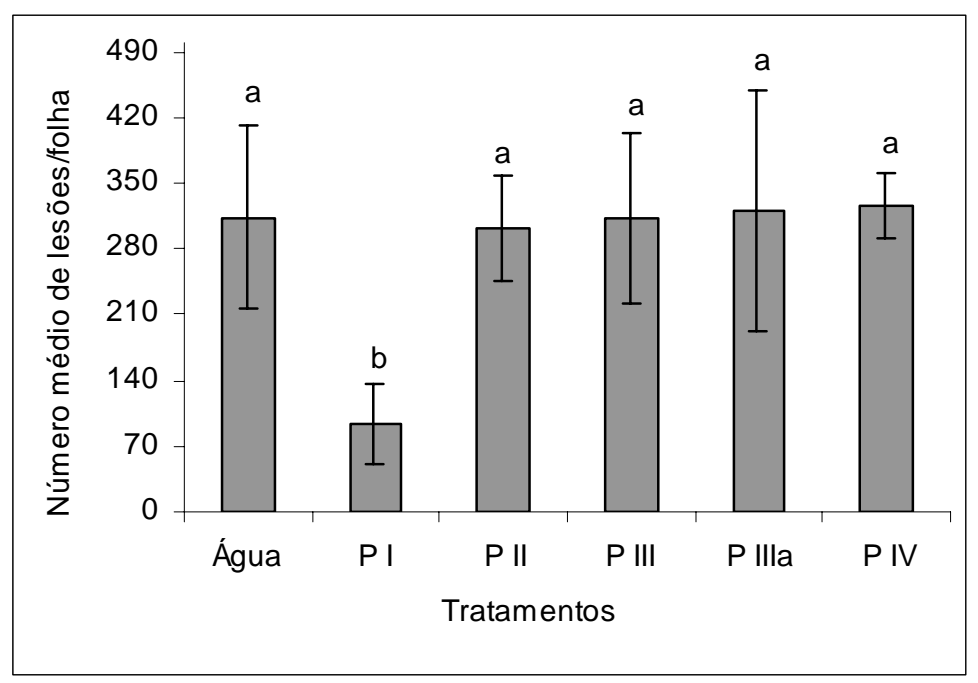

Figura 29 - Efeito local das frações agrupadas de Lentinula edodes (LE 96/22) sobre a infectividade do Tobacco mosaic virus. As frações foram obtidas por cromatografia de troca aniônica utilizando o modo "step wise” e misturadas com o inóculo viral no momento da inoculação das folhas. As colunas representam a média, enquanto as barras, o desvio padrão. Médias seguidas pela mesma letra não diferem entre si pelo teste de Tukey a 5\%. CV=30,42 $\%$ 


\section{DISCUSSÃO}

\subsection{Efeito de extratos aquosos de L. edodes sobre C. sublineolum}

No presente trabalho, observa-se que os isolados LE JAB-K e LE 95/01 de $L$. edodes apresentaram maior efeito inibitório sobre a germinação de conídios de $C$. sublineolum que os isolados LE 96/22 e LE 96/17 (Figura 6). Uma das hipóteses para explicar tal fato é que alguns isolados podem apresentar maior concentração de substâncias inibitórias ou diferir na composição dessas substâncias. Segundo Maki (1997) existem diferenças no potencial fungistático entre linhagens de L. edodes sobre Candida albicans.

Por sua vez, a formação de apressórios foi reduzida com os extratos aquosos de basidiocarpo, apesar da baixa taxa de formação dos mesmos no controle, como ilustra a Figura 7. Esta informação está de acordo com Piccinin (2000) que também observou inibição na formação de apressórios de $C$. sublineolum utilizando extratos aquosos de basidiocarpos do shiitake. A inibição dos apressórios por extratos de L. edodes pode auxiliar no controle do fitopatógeno e conseqüentemente da doença provocada pelo mesmo, pois o apressório é uma estrutura de infecção especializada que se forma a partir de uma hifa ou tubo germinativo, a qual é importante no processo de penetração do fungo através da superfície foliar do hospedeiro (Khan \& Hsiang, 2003).

Existem diferenças entre os isolados de shiitake também quanto ao efeito no crescimento de fungos fitopatogênicos in vitro. O extrato aquoso do isolado LE 96/22, adicionado sobre o meio de cultivo BDA, levou à redução do crescimento micelial de $C$. sublineolum. Piccinin (2000) verificou que os extratos aquosos de basidiocarpos, píleo ou estipe a 1 ou $2 \%$ do isolado Piracicaba, incorporados ao meio de cultivo, reduziram o 
desenvolvimento micelial do fitopatógeno. Já os extratos dos isolados LE 96/17 e LE 95/01 não alteraram o crescimento micelial de C. sublineolum (Figura 8). De modo similar, Di Piero \& Pascholati (2004b) observam que extratos de L. edodes dos isolados LE 96/17 e LE 96/22, incorporados em meio de cultivo BDA a 10\%, (v/v) não apresentaram efeito inibitório sobre o crescimento micelial de C. lagenarium agente causal da antracnose em plantas de pepino. Na mesma linha, Maki (1999) verificou que uma das linhagens de L. edodes demonstrou ser mais competente na produção de compostos inibitórios sobre Candida albicans.

Embora o extrato aquoso do isolado LE 96/22 tenha apresentado efeito inibitório no crescimento micelial de C. sublineolum, o mesmo não interferiu na germinação dos conídios do fitopatógeno. Sendo assim, o extrato aquoso de basidiocarpos do mesmo isolado pode apresentar efeito inibidor ou não para diferentes estruturas do fungo.

Com relação aos picos obtidos após CTA, apenas o pico V proporcionou atividade inibitória sobre o crescimento micelial de C. sublineolum (Figura 22), enquanto que para a germinação de esporos do patógeno, todas as frações apresentaram efeito estimulador (Figura 20). A disponibilidade de nutrientes presentes no cogumelo pode resultar no estímulo à germinação dos conídios. De acordo com Di Piero (2003), os extratos aquosos de basidiocarpos dos isolados LE 95/01 e LE 96/22 de L. edodes estimularam a germinação dos conídios de C. lagenarium.

Quanto à formação de apressório de C. sublineolum, as frações de L. edodes do isolado LE 96/22, obtidas após CTA, não apresentaram efeito inibitório (Figura 21) quando comparadas aos extratos aquosos do mesmo isolado (Figuras 7). A falta de atividade poderia ser explicada pela baixa recuperação do possível componente ativo contido no extrato e/ ou pela perda de atividade durante a preparação das amostras, etapas cromatográficas devido a desnaturação, diluição do fator de interesse, além de possíveis perdas na diálise. 


\subsection{Efeito de substâncias voláteis de $L$. edodes no crescimento micelial de $C$. sublineolum}

Metabólitos voláteis de fungos podem ser formados durante o metabolismo primário e secundário a partir da biossíntese de aminoácidos, acetato, ácidos graxos e outros (Börjesson, et al., 1993). O resultado do presente trabalho indica a influência de compostos voláteis com atividade inibitória produzidos pelo isolado LE 96/22 sobre o crescimento micelial de C. sublineolum (Figura 9).

Os cultivos miceliais dos basidiomicetos são fontes potenciais de substâncias aromáticas. Algumas destas substâncias possuem atividade antifúngica, tornando esses fungos antagonistas a outros microrganismos (Gross \& Asther, 1989). Compostos como álcoois, aldeídos, ésteres, cetonas alifáticas e compostas de enxofre fazem parte de uma série de odores característicos dos basidiomicetos (Chen et al., 1984). Mais de 18 compostos voláteis contendo enxofe já foram identificados no cogumelo shiitake fresco (Chen \& Ho, 1986). De fato, Breheret et al. (1997) investigaram os odores de compostos voláteis de 82 espécies de cogumelos frescos silvestres. Neste estudo, os autores detectaram a presença de monoterpenos em 34 espécies de cogumelo. Um total de 27 diferentes monoterpenos foi identificado como, por exemplo, limoneno, $\alpha$-pineno, entre outros. Por sua vez, Strobel et al. (2001) verificaram que a mistura de compostos voláteis produzidos por Muscodor albus, fungo endofítico, apresentou efeito antibiótico in vitro contra o crescimento de algumas espécies de oomicetos, basidiomicetos, ascomicetos, deuteromicetos, e bactérias gram-positivas e gram-negativas. Entretanto, Fusarium solani e Cercospora beticola foram parcialmente inibidos na presença dos compostos gasosos produzidos pelo fungo endofítico.

\subsection{Efeito de $L$. edodes sobre A. solani}

Os extratos aquosos de basidiocarpos dos diferentes isolados, os picos do extrato aquosos do isolado LE 96/22, obtidos após a CTA, e os compostos voláteis produzidos 
pelo micélio de $L$. edodes não demonstraram efeito inibitório no crescimento micelial e na germinação de conídios de A. solani. Os resultados podem ser explicados pela baixa concentração ou qualidade das substâncias inibitórias contidas nos extratos e nas frações de L. edodes ou ainda por fatores naturais de resistência do patógeno. Por exemplo, a melanina produzida nos conídios de Alternaria sp. (Thomma, 2003) pode ser um fator importante de resistência aos compostos antimicrobianos do cogumelo. A proteção pela melanina também foi observada em Alternaria alternata contra compostos como permanganato, hipoclorito e peróxido de hidrogênio (Jacobson et al., 1995). A melanina é um pigmento de alta massa molecular, coloração marrom-escura ou preta que está concentrado principalmente na superfície externa da parede celular do conídio (Thomma, 2003; Kawamura et al., 1999). Para a síntese da melanina, a maioria dos fungos tem como precursor o 1,8-dihidroxíliconaftaleno produzido no citoplasma e imediatamente exportado à parede celular e à matriz extracelular (Thomma, 2003). Este pigmento pode favorecer o processo de infecção do patógeno no hospedeiro, além de proteger o fungo contra as condições desfavoráveis do ambiente como temperaturas extremas, radiação UV e compostos secretados por microrganismos antagonistas, além de contribuírem com a longevidade e sobrevivência do patógeno (Kawamura et al., 1999). Em espécies de Colletotrichum, a melanina não é produzida nos esporos, mas é sintetizada no apressório, após a germinação do conídio. Para estes fungos, a síntese de melanina no apressório é um fator importante na patogenicidade (Howard \& Valent, 1996).

\subsection{Efeito de $L$. edodes sobre o crescimento de $X$. axonopodis pv. passiflorae}

Os extratos aquosos de basidiocarpos do cogumelo $L$. edodes reduziram a multiplicação de $X$. axonopodis pv. passiflorae, sendo que a redução foi dependente da concentração de extrato utilizada (Figura 13). A atividade antibiótica sobre a multiplicação de $X$. axonopodis pv. passiflorae também foi exibida por algumas frações do extrato aquoso de basidiocarpos do isolado LE 96/22, obtidas após CTA (Figura 25). 
Esses resultados estão de acordo com os encontrados por Piccinin (2000), o qual verificou que extratos de basidiocarpo, píleo e estipe a $2 \%(\mathrm{v} / \mathrm{v})$ incorporados ao meio de cultivo, reduziram a multiplicação de $X$. axonopodis pv. passiflorae.

Os extratos aquosos de basidiocarpos obtidos a partir de cultivo axênico (isolados LE 96/22 e LE 96/17) apresentaram pouca ou nenhuma redução no crescimento bacteriano quando comparados com os extratos dos mesmos isolados do cogumelo cultivados em toras de eucalipto (Figura14). A diferença talvez pudesse ser explicada pelo tipo e disponibilidade de compostos presentes no substrato. A presença ou ausência de certos nutrientes poderia influenciar a via biossintética de alguns compostos. A falta de competidores no cultivo axênico poderia talvez resultar na menor produção de compostos antibióticos pelo cogumelo, já que neste tipo de cultivo, o ambiente é mais controlado quando comparado com o cultivo do cogumelo em toras de eucalipto.

Com relação aos extratos aquosos de basidiocarpos de L. edodes submetidos à autoclavagem, os mesmos perderam a atividade antimicrobiana sobre $X$. axonopodis pv. passiflorae (Figura 15). Esse fato é um indício de que os extratos de basidiocarpos possuem substâncias antibióticas termolábeis. Piccinin (2000) constatou que, após um leve aquecimento $\left(45^{\circ} \mathrm{C}\right.$ ), os extratos aquosos de basidiocarpo, píleo e estipe também perderam o efeito inibitório sobre $X$. axonopodis pv. passiflorae. Na mesma linha, Hirasawa et al. (1999) observaram que o extrato aquoso do shiitake monstrou-se termolábel quando aquecido a $60{ }^{\circ} \mathrm{C}$ por $30 \mathrm{~min}$ reduzindo em $60 \%$ a atividade antibacteriana contra Streptococcus mutans e Prevotella intermedia e o aquecimento do extrato a $100{ }^{\circ} \mathrm{C}$ por 5 min inativou completamente a atividade antibiótica do mesmo. Entretanto, Ishikawa et al. (2001) atestaram que o tratamento térmico a $100{ }^{\circ} \mathrm{C}$ por 10 min do filtrado do crescimento micelial de L. edodes não perdeu atividade inibitória sobre Bacillus subtilis, sendo o composto estudado termoestável.

\subsection{Efeito dos extratos aquosos na infectividade do TMV em fumo}


Na área médica, há muitos trabalhos demonstrando que proteínas, carboidratos, e outras moléculas encontradas em $L$. edodes podem apresentar atividade antiviral ou ainda ativar o sistema imunológico de animais e do homem. Entretanto, na área de controle de doenças de plantas, trabalhos com L. edodes ainda são escassos.

Os extratos aquosos dos isolados LE 96/ 17 e LE 96/22 propiciaram proteção local em plantas de fumo contra TMV. O efeito protetor foi independente da concentração de extrato utilizada a partir de 10\% (Figura 16). A proteção local em fumo poderia ser explicada pela atuação direta dos compostos do cogumelo sobre as partículas virais, inibindo a infectividade do vírus.

Piccinin (2000) observou redução das lesões locais causadas por TMV em folhas de fumo pré-tratadas com extratos aquosos de basidiocarpos e lentinana.

Takagi \& Shimada (1977) verificaram que o LEM, fração extraída do micélio de L. edodes, solúvel em água, inibiu a replicação das partículas virais de TMV em plantas de fumo, além de reduzir os sintomas locais e sistêmicos nas mesmas. Da mesma forma, Takagi \& Shigimura (1977) relataram que as preparações dos basidiocarpos do shiitake foram efetivas no controle do TMV em fumo, somente quando a aplicação dos extratos foi realizada antes da inoculação do vírus ou conjuntamente com o mesmo. Na mesma linha, Kobayashi et al. (1987) também relataram o efeito inibitório de extratos do corpo de frutificação do shiitake sobre Cucumber mosaic virus (CMV) e TMV.

Os extratos de basidiocarpos dos isolados LE 96/22 e LE JAB-K a 10\% aplicados em meias-folhas de fumo reduziram a infectividade do TMV quando comparadas com aquelas pulverizadas com água destilada (Figura 17). Desta forma, existe a possibilidade de estar ocorrendo indução de resistência devido à separação espacial entre as preparações de L. edodes e o inóculo viral. Há muitos trabalhos na literatura envolvendo indução de resistência de plantas contra doenças causadas por fungos, bactérias e vírus. Por sua vez, microrganismos ou ainda moléculas de extratos de células dos mesmos podem induzir a proteção contra patógenos ativando mecanismos complexos de defesa da planta.

Di Piero (2003) constatou redução de 100\% da incidência do Passion fruit woodiness virus (PWV) em plantas de maracujá pré-tratadas com extratos aquosos de Agaricus blazei. O autor também observou que extratos de L. edodes aplicados 5 dias 
antes da inoculação de maracujazeiros conferiram proteção local significativa contra o PWV.

Os extratos aquosos de basidiocarpos autoclavados ou não autoclavados misturados à suspensão viral reduziram a infectividade do TMV em folhas de fumo (Figura 18). Portanto, os extratos aquosos de basidiocarpos de L. edodes contêm moléculas com atividade antiviral de natureza termoestável.

Dos picos obtidos através das cromatografias de troca aniônica, o pico I (frações não ligadas à coluna) foi o que apresentou maior atividade inibitória direta contra o TMV (Figuras 28 e 29). Algumas frações de L. edodes adicionadas à suspensão viral não reduziram a infectividade do TMV. Possivelmente, fatores ambientais podem interferir sobre a atividade inibitória das moléculas contidas nas frações já que os experimentos realizados com o patossitema fumo-TMV foram conduzidos em tempos e condições ambientais diferentes. Certamente, outros bioensaios com plantas de fumo deverão ser conduzidos em diferentes épocas do ano, principalmente com relação à temperatura a fim de se verificar a influência destes fatores sobre a atividade biológica dos compostos presentes no cogumelo ou ainda na replicação do TMV. 


\section{CONCLUSÕES}

O efeito antimicrobiano dos extratos aquosos de basidiocarpos foi dependente do isolado de $L$. edodes, da concentração do extrato e da natureza do agente causal.

O extrato aquoso de basidiocarpos do isolado LE 96/22 de L. edodes e o pico $\mathrm{V}$ do extrato aquoso do mesmo isolado inibiram o crescimento micelial de C. sublineolum. Já os metabólitos voláteis produzidos pelo micélio (isolado LE 96/22) de L. edodes reduziram o crescimento micelial do fipatógeno. Porém algum princípio ativo foi perdido, pois todos os picos obtidos após a cromatografia de troca aniônica do mesmo isolado estimularam a germinação de conídios e a formação de apressórios do fitopatógeno.

L. edodes não apresentou efeito inibitório na germinação de conídios e no crescimento micelial de $A$. solani.

Os filtrados do crescimento micelial e os extratos aquososos de diferentes isolados de $L$. edodes apresentaram efeito antibiótico na multiplicação de $X$. axonopodis pv. passiflorae. Porém, os extratos aquosos de basidiocarpos (LE JAB-K, LE 95/01 e LE 96/22) apresentaram molécula(s) com atividade(s) antibacteriana termolábel. O efeito antibacteriano dos extratos aquosos de basidiocarpos foi dependente do substrato de cultivo utilizado por L. edodes.

Os extratos aquosos de basidiocarpos do isolado LE 96/22 e os picos I, II e III do extrato aquososo do mesmo isolado reduziram a infectividade do TMV. Compostos antivirais de natureza termoestável estavam contidos nos extratos. 


\section{REFERÊNCIAS BIBLIOGRÁFICAS}

ALBINO, U.B. Isolamento e caracterização de fungos patogênicos à cultura de shiitake (Lentinula edodes Berk. Pegler) Londrina, 1996. Monografia (Graduação). Universidade Estadual de Londrina.

ALEXOPOULOS, C.J.; MIMS, C.W; BLACKWELL, M. Introductory mycology. 4.ed. New York: John Wiley; 1996. 869p.

BADALYAN, S.M.; INNOCENTI, G.; GARIBYAN, N.G. Antagonistic activity of xylotrophic mushrooms against pathogenic fungi of cereals in dual culture Phytopathologia Mediterranea, v.41, n.3, p. 200-225, 2002.

BIANCO, C. Basidiomycetes in relation to antibiosis. II. Antibiotic activity of mycelia and culture liquid. Bacterial and Viral Immunology, v.75, p.267-274, 1981.

BÖRJESSON, T.; STÖLLMAN, U.; SCHNÜRER, J. Off-odorous compounds produced by moulds on oatmeal agar. Identification and relations to other growth characteristics. Journal of Agricultural and Food Chemistry, v. 41, p.2104-2111, 1993.

BRADFORD, M. A. A rapid and sensitive method for the quantitation of microgram quanties of protein utilizing the principle of protein-dye binding. Analytical Biochemistry, v.72, n.1/2, p.248-254, 1976. 
BREENE, W.M. Nutritional and medicinal value of specialty mushrooms. Jornal of Food Protection, v.53, n.10, p.883-894,1990.

BREHERET, S.; TALOU, T.; RAPIOR, S.; BESSIÈRE, J.M. Monoterpenes in the aromas of fresh wild mushrooms (Basidiomycetes). Journal of Agricultural and Food Chemistry, v.45, n.3, p.831-836, 1997.

BROWNING, M.; ROWLEY, L. V.; ZENG, P.; CHANDLEE, J. M.; JACKSON, N. Morphological, pathogenic, and genetic comparisons of Colletotrichum graminicola isolates from poaceae. Plant Disease, v.83, n.3, p.286-292, 1999.

BURKETOVÁ, L.; STILLEROVÁ, K.; FELTLOVÁ, M. Immunohistological localization of chitinase and $\beta$-1,3-glucanase in rhizomania-diseased and benzothiazole treated sugar beet roots. Physiological and Molecular Plant Pathology, v.63, n.1, p.47-54, 2003.

CHANG, S.T. Cultivated mushrooms in hand book of applied mycology. In: Arora, D. K.; MUKERJI, K.G.; MARTH, E.H. Food and feeds. New York: Marcel Dekker, 1991, v.3, p.221-240.

CHANG, S.T.; MILES, P.G. Edible mushrooms and their cultivation. Boca Raton: CRC Press, 1989. 345p.

CHEN C.; BÉLANGER, R.R.; BENHAMOU, N.; PAULITZ, T.C. Induced systemic resistance (ISR) by Peseudomonas spp. impairs pre and post infection development of Pythium aphanidermatum on cucumber roots. European Journal of Plant Pathology, v. 104, n.9, p.877-886, 1998. 
CHEN, C.C.; HO, C.T. Identification of sulfurous compounds of shiitake mushroom (Lentinula edodes Sing.). Journal of Agricultural and Food Chemistry, v.34, n.5, p.830-833, 1986.

CHEN, C.C.; CHEN, S.D.; CHEN, J.J.; WU, C.M. Effect of pH value on the formation of volatiles of shiitake (Lentinula edodes), an edible mushroom. Journal and Agricultural and Food Chemistry, v.32, n.6, p.99-1001, 1984.

CHIHARA, G.; MAEDA, Y.; HAMURO, J.; SASAKI, T.; FUKUOKA, W. Inhibition of mouse sarcoma 180 by polyssacharides from Lentinula edodes. Nature, v.222, p.687-688, 1969.

COOK, R.J.; BAKER, K.F. The nature and practice of biological control of plant pathogens. Saint Paul: The American Phytopathological Society, 1983. 539p.

CRISAN, E.V.; SANDS, A. Nutritional value. In: CHANG, S.T.; HAYES, W.A. The biology and cultivation of edible mushrooms. New York: Academic Press, 1978. p.137-168.

DESILETS, H. BANHAMOU, BÉLANGER, R. R. A comparative study of histological and ultrastructural alterations induced by Pythium ultimum or its metabolites on geranium (Pelargonium) roots. Physiological and Molecular Plant Pathology, v.45, n.1, p. 21-36, 1994. 
DI PIERO, R.M. Potencial dos cogumelos Lentinula edodes (Shiitake) e Agaricus blazei (Cogumelo-do-Sol) no controle de doenças em plantas de pepino, maracujá e tomate, e a purificação parcial de compostos biologicamente ativos. Piracicaba, 2003. 157p. Tese (Doutorado) - Escola Superior de Agricultura “Luiz de Queiroz”, Universidade de São Paulo.

DI PIERO R.M.; PASCHOLATI, S.F. Efeito dos cogumelos Lentinula edodes e Agaricus blazei na interação entre plantas de tomate e Xanthomonas vesicatoria. Summa Phytopathologica, v.30, n.1, p.57-62, 2004a.

DI PIERO, R.M.; PASCHOLATI, S.F. Indução de resistência em plantas de pepino contra Colletotrichum lagenarium pela aplicação de extratos de basidiocarpos de Lentinula edodes e Agaricus blazei. Summa Phytopathologica, v.30, n.2, p.243-250, 2004b.

DIXON, R. A.; LAMB, C. J. Molecular communication in interactions between plants and microbial pathogens. Annual Review of Plant Physiology and Plant Molecular Biology, v.41, p.339, 1990.

DUBOIS, M.; HAMINTON, K.; REBERS, P.; SMITH, C. Colorimetric methods for determination of sugar and related substances. Analytical Chemistry, v.167, p.350356, 1956.

FERREIRA, J.E. Produção de cogumelos. Guaíba: Livraria e Editora Agropecuária, 1998. 135p. 
FRAVEL, D.R. Role of antibiosis in the biocontrol of plant. Annual Review of Phytopathology, v.26, p.75-91, 1988.

FREDERIKSEN, R.A. Compendium of sorghum diseases. 2.ed. Saint Paul: The American Phytopathological Society, 1991. 82p.

GHAOUTH, A. E.; WILSON, C. L.; CALLAHAN, A. M. Induction of chitinase, $\beta-1,3$ glucanase, and phenylalanine ammonia-lyase in peach fruit by UV-C treatment. Biological Control, v.93, n.3, p.349-355, 2003.

GHAOUTH, A. E.; WILSON, C. L.; WISNIEWSKI, M. Control of postharvest decay of apple fruit with Candida saitoana and induction of defense responses. Phytopathology, v.93, n.3, p.344-348, 2003.

GODOY, C.V.; SALGADO, C.L. Doenças do fumo. In: KIMATI, H. AMORIM, L. BERGAMIN FILHO, A.; CAMARGO, L.E.A.; REZENDE, J.A.M. (Ed). Manual de fitopatologia: doenças das plantas cultivadas. 3.ed. São Paulo: Agronômica Ceres, 1997.v.2, p.411-420.

GONÇALVES, E. R.; ROSATO, Y. B. Genotypic characterization of xanthomonad strains isolated from passion fruit plants (Passiflora spp.) and their relatedness to different Xanthomonas species. International Journal of Systematic and Evolutionary Microbiology, v.50, n.2, p.811-821, 2000.

GRIFFIN, D.H. Fungal physiology. 2. ed. New York: Wiley-Liss, 1994. 523 p. 
GROSS, B.; ASTHER, M. Aromas from Basidiomycetes: characteristics, analysis and productions. Science Aliments, v.9, p.427-454, 1989.

HATVANI, N. Antibacterial effect of the culture fluid of Lentinula edodes mycelium grown in submerged liquid culture. International Journal of Antimicrobial Agents, v.17, p.71-74, 2001.

HE, C. Y.; HSIANG T.,WOLYN, D. J. Induction of systemic disease resistance and pathogen defence responses in Asparagus officinalis inoculated with nonpathogenic strain of Fusarium oxysporum. Plant Pathology, v.51, n.2, p.225-230, 2002.

HIRASAWA, M.; SHOUJI, N; NETA, T.; FUKUSHIMA, K.; TAKADA, K. Three kinds of antibacterial substances from Lentinus edodes (Berk.) Sing. (Shiitake, an edible mushroom). International Journal of Antimicrobial Agents, v.11, p. 151157, 1999.

HOWARD, R.J.; VALENT, B. Breaking and entering: host penetration by the fungal rice blast pathogen Magnaporthe grisea. Annual Review of Microbiology, v.50, p.491-512, 1996.

ISHIKAWA, N.K. Avaliação da atividade antagonista de Lentinula edodes. Viçosa, 1997. Dissertação (Mestrado)-Universidade Federal de Viçosa.

ISHIKAWA, N.K.; KASUYA, M.C.M.; VANETTI, M.C.D. Antibacterial activity of Lentinula edodes grown in liquid medium. Brazilian Journal of Microbiology, v.32, n.3, p.206-210, 2001. 
JACKSON, A.J.; WALTERS, D.R.; MARSHALL, G. Antagonistic interaction between the foliar pathogen Botrytis fabae and isolates of Penicillium brevicompactum and Cladosporium cladosporioides on faba beans. Biological Control, v.8, p.97-106, 1997.

JACOBSON, E. S.; HOVE, E.; EMERY, H. S. Antioxidant function of melanin in black fungi. Infection and Immunity.,v.63, p.4944-4945, 1995.

JONG, S.C.; BIRMINGHAM, J.M. Medicinal and therapeutic value of the shiitake mushroom. Advances in Applied Microbiology. London: Academic Press, v.39, p.153-184, 1993.

KAWAMURA, C. TSUJIMOTO, T. TSUGE, T. Targeted disruption of melanin biosynthesis gene affects conidial development and UV tolerance in the japanese pear pathotype of Alternaria alternata. Molecular Plant-Microbe Interactions, v.12, n.1, p.59-63, 1999.

KHAN, A.; HSIANG, T. The infection process of Colletotrichum graminicola and relative aggressiveness on four turfgrass species. Canadian Journal of Microbiology, v.49, p.433-442, 2003.

KIM, K.K., FRAVEL, D.R. PAPAVIZAS, G.C. Identification of a metabolite produced by Talaromyces flavus as glucose oxidase and its role in the biocontrol of Verticillium dahliae. Phytopathology, v.78, n.4, p. 488-492, 1988. 
KOBAYASHI, N.; HIRAMATSU, A.; AKASUKA, T. Purification and chemical properties of an inhibitor of plant virus infection from fruiting bodies of Lentinus edodes. Agricultural and Biological Chemistry, v.51, n.3, p.883-890, 1987.

KOIKE, N. HYAKUMACHI, M.; KAGEYAMA, K.; TSUYUMU, S.; DOKE, N. Induction of systemic resistance in cucumber agaist several diseases by plant growthpromoting fungi: lignification and superoxide generation. European Journal of Plant Pathology, v.107, n.5, p.523-533, 2001.

KUPPER, K.C.; GIMENES-FERNANDES, N.; GOES, A. Controle biológico de Colletotrichum acutatum, agente causal da queda prematura dos frutos cítricos. Fitopatologia Brasileira, v.28, n.3, p.251-257, 2003.

KUROZAWA, C.; PAVAN, M.A. Doenças do tomateiro. In: KIMATI, H. AMORIN, L. BERGAMIN FILHO, A.; CAMARGO, L.E.A.; REZENDE, J.A.M. (Ed) Manual de fitopatologia: doenças das plantas cultivadas. 3.ed. São Paulo: Agronômica Ceres, 1997. v.2, cap.64, p.690-719.

LABANCA, E.R.G. Purificação parcial de elicitores presentes em Saccharomyces cerevisiae: atividade como indutores de resistência em pepino (Cucumis sativus) contra Colletotrichum lagenarium e da síntese de gliceolinas em soja (Glycine max). Piracicaba, 2002. 107 p. Dissertação (Mestrado) - Escola Superior de Agricultura “Luiz de Queiroz”, Universidade de São Paulo.

LEATHAM, G. F. Extracellular enzymes produced by the cultivated mushroom Lentinus edodes during degradation of lignocellulosic medium. Applied and Enviroment Microbiology, v.50, n4, p.859-867, 1985. 
LO, S.C.; DE VERDIER, K.; NICHOLSON, R. L. Accumulation of 3deoxyanthocyanidin phytoalexins and resistance to Colletotrichum sublineolum in sorghum. Physiological and Molecular Plant Pathology, v.55, n.5, p.263-273, 1999.

LO, S. C.; WEIERGANG, I.; BONHAM, C.; HIPSKIND, J.; WOOD, K. NICHOLSON, R. L. Phytoalexin accumulation in sorghum: Identification of a methyl ether of luteolinidin. Physiological and Molecular Plant Pathology, v.49, n.1, p.21-31, 1996.

LOBANOK, A.G.; BABITSKAYA, V.G.; PLENINA, L.V.; PUCHKOVA, T.A; OSADCHAYA, O.V. Composition and biological activity of submerged mycelium of the xylotrophic basidiomycete Lentinula edodes. Applied Biochemistry and Microbiology, v.39, n.1, p.69-73, 2003.

LOBO Jr, M.; ABREU, M.S. Inibição do crescimento micelial de Sclerotinia sclerotiorum por metabólitos voláteis produzidos por alguns fungos antagonistas em diferentes temperaturas e pH’s. Ciência e Agrotecnologia, v.24, n.2, p.521-526, 2000.

LOPEZ, A. M. Q.; PASCHOLATI, S. F. Accumulation of a complex of pigments in sorghum mesocotyls in response to wounding. Journal of Phytopathology, v.135, p.63-70, 1992.

LUZ, W.C. Microbiolização de sementes para o controle de doenças das plantas. In: LUZ, W.C. (Ed.) Revisão anual de patologia de plantas. Passo Fundo: Revisão Anual de Patologia de Plantas, 1993. cap 9, p.33-77. 
MAKI, C.S. Avaliação do efeito antagônico de cogumelos comestíveis sobre Candida albicans (Robin) Berkout. Londrina. 1997. Monografia (Graduação) - Universidade Estadual de Londrina.

MAKI, C.S. Respostas fungistáticas de Lentinula edodes sobre Candida albicans e análise da variabilidade intraespecífica. Londrina, 1999. 109p. Dissertação (M.S.) Universidade Estadual de Londrina.

MAKKAR, R. S.; TSUNEDA, A.; TOKUYASU, K.; MORI, Y. Lentinula edodes produces a multicomponent protein complex containing manganese (II)-dependent peroxidase, laccase and $\beta$-glucosidase. FEMS Microbiology Letters, v.200, n.2, p.175-179, 2001.

MALAVOLTA JÚNIOR, V. A. Bacterioses do maracujazeiro. In: SIMPÓSIO BRASILEIRO DO MARACUJAZEIRO, 5, Jaboticabal, 1998. Anais Jaboticabal: FUNEP, 1998. p.217-229.

MALAVOLTA JÚNIOR, V. A.; BERIAM, L. O. S.; RODRIGUES NETO, J. Podridão do fruto, novo sintoma relacionado a Xanthomonas axonopodis pv. passiflorae. Arquivos do Instituto Biológico, v.68, n.2, p.121-123, 2001.

MANDER, M.; FUSSI, R. Role of peroxidase in lignification of tobacco cell: regulation by phenolic compounds. Plant Physiology, v.70, p.1132-1134, 1982.

MÁS, P.; BEACHY, R. N. Replication of Tobacco mosaic virus on endoplasmic reticulum and role of the cytoskeleton and virus movement protein in intracellular distribution of viral RNA. The Journal of Cell Biology, v.147, n.5, p.945-958, 1999. 
MÉTRAUX, J.P. Systemic acquired resistance and salicylic acid: currente state of knowledge. European Journal of Plant Pathology, v. 107, n.1, p.13-18, 2001.

MIZUNO, T. Bioactive biomolecules of mushrooms: food function and medicinal effect of mushroom fungi. Food Review International, v.11, n.1, p.7-21, 1995a.

MONTINI, R.M.C. Efeito de linhagens e substratos no crescimento miceliano e produtividade em cultivo axênico de shiitake (Lentinula edodes (Berk.) Pegler). Botucatu, 2001. 97 p.Tese (Doutorado) - Faculdade de Ciências Agronômicas, Universidade Estadual Paulista “Júlio de Mesquita Filho”.

MORAES, M. G. Mecanismos da resistência sistêmica adquirida em plantas. Revisão Anual de Patologia de Plantas, v.6, p. 261-284, 1998.

MORENO, A.B.; MARTÍNEZ DEL POZO, Á.; BORJA, M., SAN SEGUNDO, B. Activity of the antifungal protein from Aspergillus giganteus against Botrytis cinerea Phytopathology,v. 93, n.11, p.1344-1353, 2003.

MORITA, S.; AZUMA, M.; AOBA, T.; SATOU, H.; NARISAWA, K.; HASHIBA, T. Induced systemic resistance of chinese cabbage to bacterial leaf spot and Alternaria leaf spot by the root endophytic fungus, Heteroconium chaetospira. Journal of General Plant Pathology, v. 69, n.1, p. 71-75, 2003.

MOUSSAÏf, M.; JACQUES, P.; SCHAARWÄCHTER, P.; BUDZKIEWICZ, H.; THONART, P. Cyclosporin $\mathrm{C}$ is the main antifungal compound produced by Acremonium luzulae. Applied and Environmental Microbiology, v.63, n.5, p.17391743, 1997. 
OKU, H. Plant pathogenesis and disease control. London: CRC Press, 1994.

PACUMBABA, R.P.; BEYL, C.A.; PACUMBABA, R.O. Shiitake mycelial leachate supresses growth of some bacterial species and symptoms of bacterial wilt of tomato and lima bean in vitro. Plant Disease, v.83, n.1, p.20-23, 1999.

PANIZZI, R.C.; FERNANDES, N.G. Doenças do sorgo. In: KIMATI, H. AMORIM, L. BERGAMIN FILHO, A.; CAMARGO, L.E.A.; REZENDE, J.A.M. (Ed.). Manual de fitopatologia: doenças das plantas cultivadas. 3. ed. São Paulo: Agronômica Ceres, 1997. v.2, cap.63, p.676-677.

PASCHOLATI, S. F.; STANGARLIN, J.R.; PICCININ, E. Cogumelos: cultivo e comercialização (Shiitake e Cogumelo do Sol). Cuiabá: SEBRAE/MT, 1998. 85 p. (Coleção Agroindústria, 17).

PASCHOLATI, S.F.; LEITE, B. Hospedeiro: mecanismos de resistências. In: BERGAMIN FILHO, A.; KIMATI, H.; AMORIM, L. (Ed.). Manual de fitopatologia: princípios e conceitos. São Paulo: Agronômico Ceres, 1995. v.1, p. 417-454.

PICCININ, E. Potencial de preparações do cogumelo comestível shiitake (Lentinula edodes) no controle de fitopatógenos fúngicos, bacterianos e virais em sorgo, maracujá e fumo. Piracicaba, 2000. 162p. Tese (Doutorado) - Escola Superior de Agricultura “Luiz de Queiroz”, Universidade de São Paulo. 
PIO-RIBEIRO, G.; MARIANO, R.L.R. Doenças do maracujazeiro. In: KIMATI, H. AMORIM, L. BERGAMIN FILHO, A.; CAMARGO, L.E.A.; REZENDE, J.A.M. (Ed.). Manual de fitopatologia: doenças das plantas cultivadas. 3. ed. São Paulo: Editora Agronômica Ceres Ltda, 1997, v.2, cap.63, p.676-677.

PRZYBYLOWICZ, P.; DONOGHUE, J. Shiitake growers handbook: the art and science of mushroom cultivation. Dubuque: Kendall; Hunt Publ., 1990.217 p.

RAUPACH, G.S., LIU, L.; MURPHY, J.F.; TUZUN, S.; KLOEPPER, J.W. Induced systemic resistance in cucumber and tomato agaist cucumber mosaic cucumovirus using plant growth-promoting rhizobacteria (PGPR). Plant Disease, v. 80, n.8, p.891894, 1996.

ROYSE, D.J.; SCHISLER, L.C.; DIEHLE, D.A. Shiitake mushroom: consumption, production and cultivation. Interdisciplinary Science Reviews, v.10, n.4, p.329335, 1995.

RYALLS, J.; NEUENSCHWANDER, U.; WILLITS, M.; MOLINA, A.; STEINER, H. Y; HUNT, M. Systemic acquired resistance. Plant Cell, v.8, p.1809-1819, 1996.

SABOTA, C. Strain of shiitake mushroom [Lentinula edodes (Berk.) Pegler] and wood species affect the yield of shiitake mushrooms. Hort Technology, v.6; n.4, p.388393, 1996.

SAN ANTONIO, J.P. Cultivation of the shiitake mushroom. HortScience, v.16, n.2, p.151-156, 1981. 
SASAKI, S.H.; LINHARES, R.E.C.; NOZAWA, C.M.; MONTALVÁN, R.; PACCOLA-MEIRELLES, L.D. Strains of Lentinula edodes suppress growth of phytopathogenic fungi and inhibit alagoas serotype of vesicular stomatitis virus. Brazilian Journal of Microbiology, v.32, p.52-55, 2001.

SHEW, H.D.; LUCAS, G.B. Compendium of tobacco diseases. Saint Paul: The American Phytopathological Society, 1990. 68p.

SIMARDI, M.; RIOUX, D.; LAFLAMME, G. Formation of ligno-suberized tissues in jack pine resistant to the european race of Gremmeniella abietina. Biochemistry and Cell Biology, v.91, n.12, p.1128-1139, 2001.

SINGER, R. Mushrooms and truffles: botany, cultivation and utilization. London: Leonard Hill, 1961. 272p.

SINGH, U .S.; DOUGHTY, K. J.; NASHAAT, N.I.; BENNETT, R. N; KOLTE, S. J. Induction of systemic resistance to Albugo candida in Brassica juncea by pre or coinoculation with an incompatible isolate. Phytopathology, v.89, n.12, 1226-1232, 1999.

SMITH, C.G. Accumulation of phytoalexins: defense mechanism and stimulus response system. New Phytologist, v.132, p. 1-45, 1996.

SOLÓRZANO, E.; PETEIRA, B.; FERNÁNDEZ, A. Induccion de beta 1-3 glucanasas em plantas de tomate infectadas com Alternaria solani. Revista Protección Vegetal, v.11, n.3, p.183-185, 1996. 
STANGARLIN, J. R.; PASCHOLATI, S. F. Proteção de plântulas de milho pipoca contra Exserohilum turcicum pelo uso de Saccharomyces cerevisiae. Summa Phytopathologica, v.20, n.1, p.16-21, 1994.

STEVENSON, R.E.; PENNYPACKER, S.P. Effect of radiation, temperature, and moisture on conidial germination of Alternaria solani. Phytopathology, v.78, n.7, p.926-930, 1988.

STROBEL, G.A.; DIRKSE, E.; SEARS, J.; MARKWORTH, C. Volatile antimicrobials from Muscodor albus, a novel endophytic fungus. Microbiology, v.147, n.11, p.2943-2950, 2001.

SUGANO, N.; HIBINO, Y.; CHOJI, Y.; MAEDA, H. Anticarcinogenic actions of water-soluble and alcohol insoluble fractions from culture medium of Lentinus edodes mycelia. Cancer Letters, v.17, n.2, p.109-114, 1982.

SUTHERLAND, M. W. The generation of oxygen radicals during host plant responses to infection. Physiological and Molecular Plant Pathology, v.39, n.2, p.79-93, 1991.

SUZUKI, F.; SUZUKI, C.; SHIMOMURA, E.; MAEDA, H.; FUJII, T.; ISHIDA, N. Antiviral and interferon-inducing activities of a new peptidomannan, KS-2, extracted from culture mycelia of Lentinula edodes. Journal of Antibiotics, v.32, n.12, p.1336-1345, 1979. 
SUZUKI, H.; ILYAMA, K.; YOSHIDA, O.; YAMAZAKI, S.; YAMAMOTO, N.;

TODA, S. Structural characterization of the immunoactive and antiviral watersolubilized lignin in an extract of the culture medium of Lentinus edodes mycelia (LEM). Agricultural and Biological Chemistry, v.54, n.2, p.479-487, 1990.

TAKAGI, Y., SHIMADA, K. Inhibitory effect of aqueous extracts from the sawdust rice bran media on which Lentinus edodes or Flamulina velutipes had grown. Annals of the Phytopathological Society of Japan, v.43, n.2, p.211-214, 1977.

TAKAGI, Y.; SHIGIMURA, Y. Inhibitory effect of aqueous extract of fruit bodies of Lentinus edodes (berk.) Sing. on plant virus. Proceedings of the Kansai Plant Protection Society, n.6, p.11-16, 1977.

TAKENAKA, S.; NISHIO, Z.; NAKAMURA, Y. Induction of defense reactions in sugar beet and wheat by treatment with cell wall protein fractions from the mycoparasite Pythium oligandrum. Phytopathology, v.93, n.10, p.1228-1232, 2003.

TASSA, S. O. M. E. ; DUARTE, V. Ocorrência de mancha bacteriana causada por Xanthomonas axonopodis pv. passiflorae, em maracujazeiro no Estado de Mato Grosso. Fitopatologia Brasileira, v.27, n.6, p.647, 2002.

TEIXEIRA, E. M. Caracterização isoenzimática e molecular de Lentinula edodes e avaliação da produção em função da espécie de eucalipto e clima. Araraquara, 2000. 123p. Tese (Doutorado) - Instituto de Química, Universidade Estadual Paulista.

THOMMA, B.P.H.J. Alternaria spp.: from general saprophyte to specific parasite. Molecular-Plant Pathology, v.4, n.4, p.225-236, 2003. 
WASSER, S.P.; WEIS, A.L. Therapeutic effects of substances occurring in higher basidiomycetes mushrooms: a modern perspective. Critical Reviews in Immunology, v.19, n.1, p.65-96, 1999.

WHARTON, P. S.; JULIAN, A. M.; O' CONNELL, R. J. Ultrastructure of the infection of Sorghum bicolor by Colletotrichum sublineolum. Phytopathology, v.91, n.2, p.149-158, 2001.

WIEST, A.; GRZEGORSKI, D.; XU, B.W.; GOULARD, C.; REBUFFAT, S.; EBBOLE, D.J.; BODO, B.; KENERLEY, C. Identification of peptaibols from Trichoderma virens and cloning of a peptaibol synthetase. The Journal of Biologycal Chemistry, v.277, n.23, p. 20862-20868, 2002.

WILLITS, M.G.; RYALS, J. A. Determining the relationship between salicylic acid levels and systemic acquired resistance induction in tobacco. Molecular Plant Microbe Interactions. v. 11, n.8, p.795-800, 1998.

WULFF, N. A.; PASCHOLATI, S. F. Partial characterization of sorghum phytoalexin elicitors isolated from Saccharomyces cerevisiae. Fitopatologia Brasileira, v.24, n.3, p.428-435, 1999.

XUE, L.; CHAREST, P. M.; JABAJI-HARE, S. H. Systemic induction of peroxidases, 1,3- $\beta$-glucanase, chitinases, and resistance in bean plants by binucleate Rhizoctonia species. Biologicol Control, v.88, n.4, p. 359-365, 1998. 
YOHALEM, D.S.; NORDHEIM, E.V.; ANDREWS, J.H. The effect of water extracts of spent mushroom compost on apple scab in the field. Biological Control, v.86, n. 9, p.914-922, 1996.

ZHANG, S.; REDDY, M.S.; KLOEPPER, J.W. Development of assays for assessing induced systemic resistance by plant growth promoting rhizobacteria against blue mold of tobacco. Biological Control, v. 23, n.1, p. 79-86, 2002. 
APÊNDICE 
APÊNDICE 1 - (a) Curva padão para a dosagem de proteínas através do método de Bradford; (b) Curva padrão para a dosagem de carboidratos totais através do método fenol sulfúrico
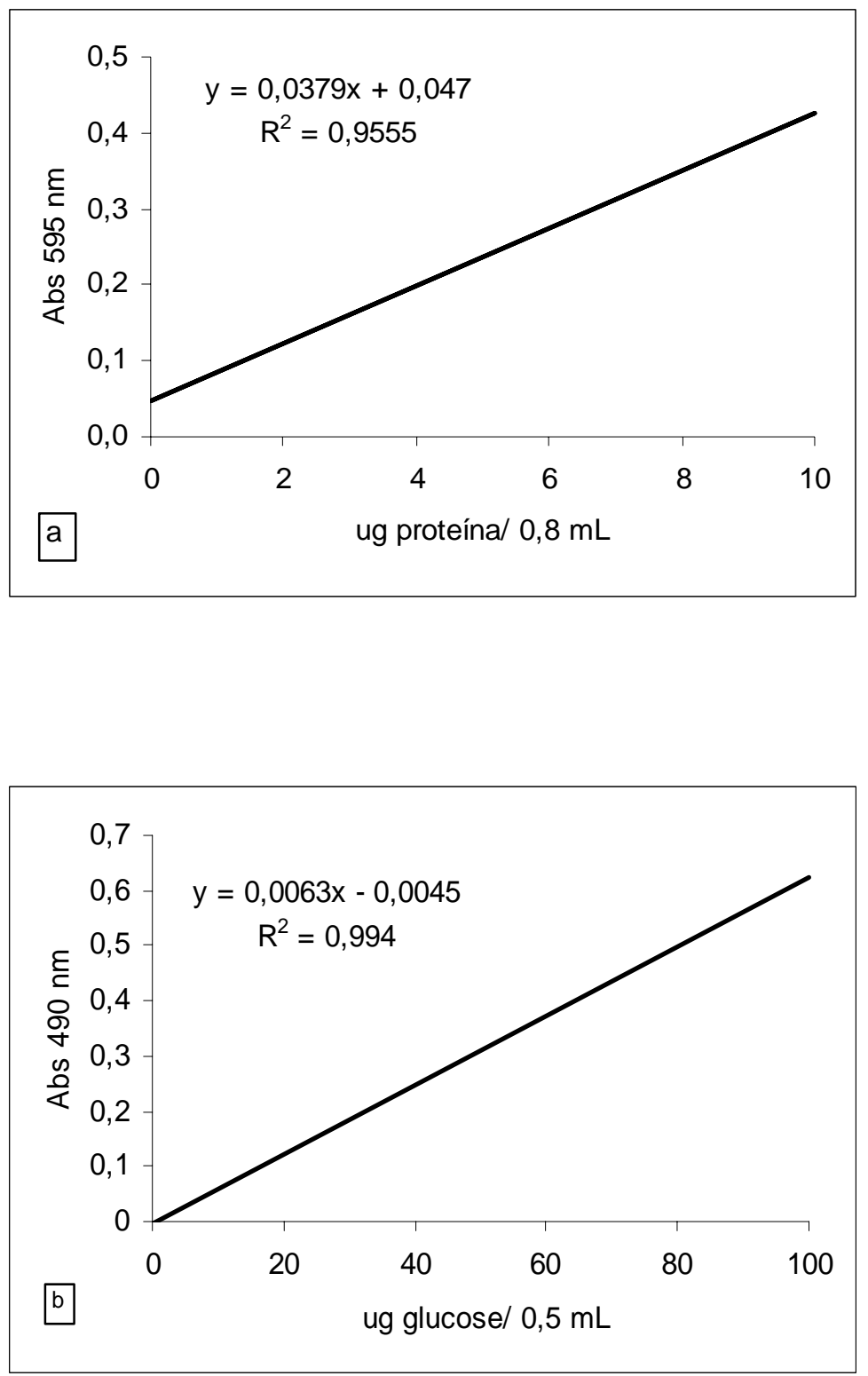
APÊNDICE 2 - Frações representadas por diferentes picos ilustrados nas Figuras 19, 26 e 27

Figura 19

Pico I - frações 7 a 11;

Pico II - frações 25 a 29;

Pico III - frações 39 a 43;

Pico IV - frações 47 a 51;

Pico V - frações 55 a 59;

Pico VI - frações 69 a 73;

Pico VII - frações 81 a 85.

Figura 26

Pico I - frações 14 a 18;

Pico II - frações 55 a 58;

Pico III - frações 72 a 75;

Pico IV - frações 81 a 83.

\section{Figura 27}

Pico I - frações 4 a 7;

Pico II - frações 43 a 45;

Pico III - frações 48 a 50;

Pico IIIa - frações 52 a 55;

Pico IV - frações 63 a 65. 